\title{
Horseshoe kidneys : implications for transplantation and vascular surgery
}

Citation for published version (APA):

Stroosma, O. B. (2001). Horseshoe kidneys : implications for transplantation and vascular surgery.

[Doctoral Thesis, Maastricht University]. Universiteit Maastricht. https://doi.org/10.26481/dis.20011018os

Document status and date:

Published: 01/01/2001

DOI:

$10.26481 /$ dis.20011018os

Document Version:

Publisher's PDF, also known as Version of record

\section{Please check the document version of this publication:}

- A submitted manuscript is the version of the article upon submission and before peer-review. There can be important differences between the submitted version and the official published version of record.

People interested in the research are advised to contact the author for the final version of the publication, or visit the DOI to the publisher's website.

- The final author version and the galley proof are versions of the publication after peer review.

- The final published version features the final layout of the paper including the volume, issue and page numbers.

Link to publication

\footnotetext{
General rights rights.

- You may freely distribute the URL identifying the publication in the public portal. please follow below link for the End User Agreement:

www.umlib.nl/taverne-license

Take down policy

If you believe that this document breaches copyright please contact us at:

repository@maastrichtuniversity.nl

providing details and we will investigate your claim.
}

Copyright and moral rights for the publications made accessible in the public portal are retained by the authors and/or other copyright owners and it is a condition of accessing publications that users recognise and abide by the legal requirements associated with these

- Users may download and print one copy of any publication from the public portal for the purpose of private study or research.

- You may not further distribute the material or use it for any profit-making activity or commercial gain

If the publication is distributed under the terms of Article $25 \mathrm{fa}$ of the Dutch Copyright Act, indicated by the "Taverne" license above, 


\section{Horseshoe kidneys}

Implications for transplantation

and vascular surgery 
ISBN $90-9015024-2$

OMSLAg ILluStratiE: Annelies Hoek, Weert

Vormgeving \& Productie: Mady Reliëf Pre Press, Landgraaf

Fianancial support of the Dutch Kidney Foundation for publication of this thesis is gratefully acknowledged.

Financial support of Aventis Pharma BV, Fujisawa Holland BV, Gambro BV, Lamepro BV, Nijmeegse Taxi Centrale, Novartis Pharma BV, Pfizer BV, Porgès SA, Roche Nederland BV, Sanofi-Synthélabo, Stroosma Consult BV, Tramedico BV, Wyeth and Yamanouchi Pharma BV is also gratefully acknowledged.

Copyright O2001, Horseshoe kidneys. O.B. Stroosma, Maastricht

No part of this book may be reproduced or transmitted in any form or by other means, electronic, mechanical. photocopying, recording or otherwise, without the written permission from the copyright owner. 


\section{Horseshoe kidneys}

Implications for transplantation

and vascular surgery

\section{PROEFSCHRIFT}

ter verkrijging van de graad van doctor aan de Universiteit Maastricht,

op gezag van de Rector Magnificus, Prof. Dr. A.C. Nieuwenhuijzen Kruseman volgens het besluit van het College van Decanen.

in het openbaar te verdedigen

op donderdag 18 oktober 2001 om 16.00 uur

door

Otto Bernardus Stroosma

geboren op 8 oktober 1971 te Amsterdam 
Promotor:

Co-Promotor:

Beoordelingscommissie: Prof. Dr. Ph.E.V.A. van Kerrebroeck (voorzitter) Prof. Dr. J.H. van Bockel (Leids Universitair Medisch Centrum) Prof. Dr. J.P. van Hooff

Dr. H. van Mameren

Prof. Dr. P.H. Petritsch (Universitätsklinikum Graz, Österreich) 


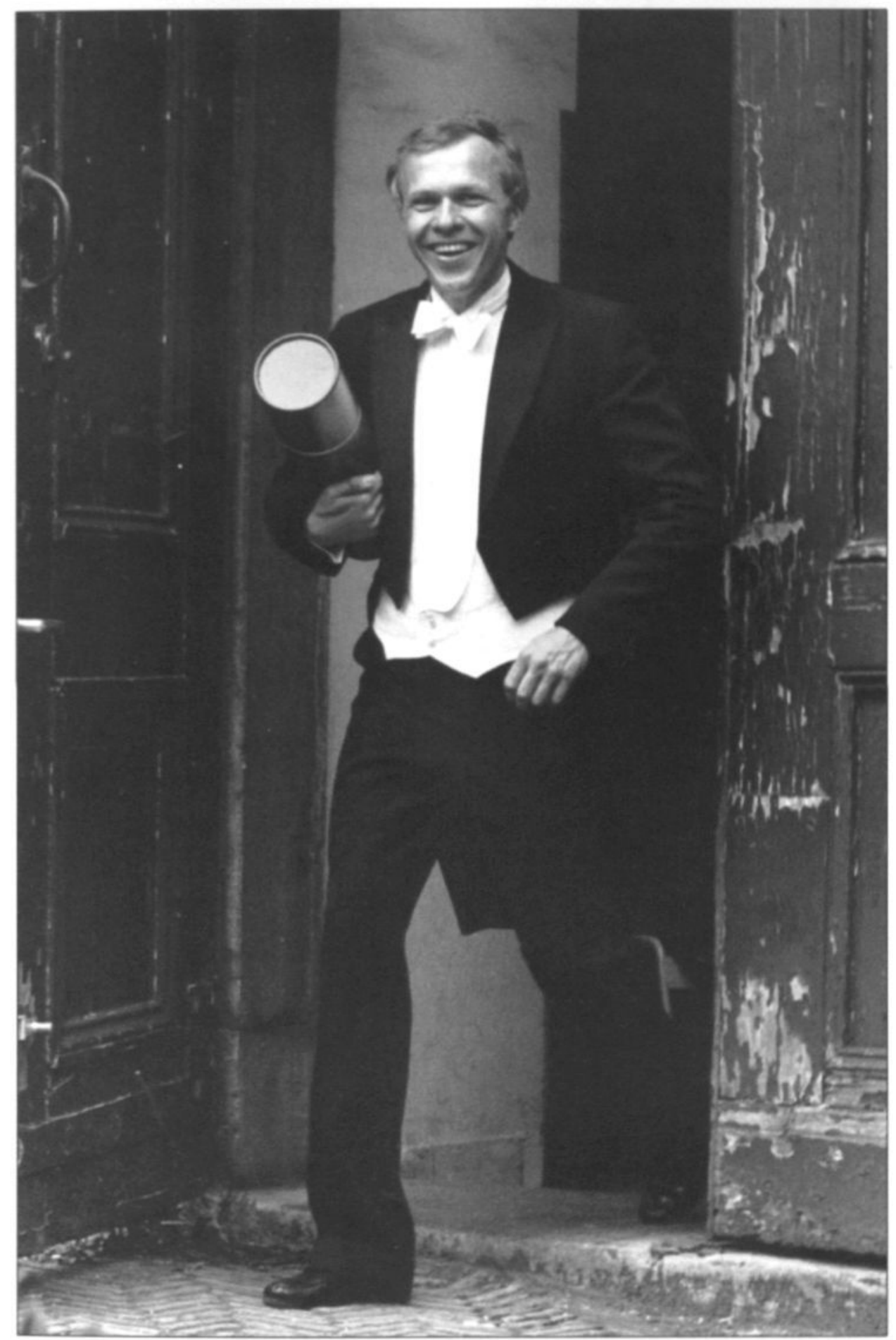

$27 \cdot 05 \cdot 1982$

AAN OTTO SR.

MIJN VADER, MIJN VOORBEELD

EN BOVENAL MIJN BESTE VRIEND 
CONTENTS

$\begin{array}{ll}\text { CHAPTER } 1 \text { General Introduction } & 7\end{array}$

$\begin{array}{ll}\text { CHAPTER } 2 \text { Anatomy and Embryology } & 17\end{array}$

$\begin{array}{lll}\text { CHAPTER } 3 \text { Horseshoe kidneys in historical perspective } 23 & 23\end{array}$

CHAPTER 4 Horseshoe kidney transplantation: An overview 35

ChAPTER 5 Current opinions in horseshoe kidney transplantation 43

$\begin{array}{lll}\text { ChAPTER } 6 & \text { Horseshoe kidney transplantation } & 49\end{array}$ within the Eurotransplant region:

A case control study

CHAPTER 7 Transplanting horseshoe kidneys: A worldwide survey $\quad 59$

$\begin{array}{lll}\text { Chapter } 8 & \text { Case reports } & 69\end{array}$

Successful transplantation of a divided horseshoe kidney following prolonged donor hypotension and long distance transportation:

A case report

Transplanting horseshoe kidneys: the Maastricht experience

$\begin{array}{lll}\text { CHAPTER } 9 & \text { The management of aortic aneurysms } & 73\end{array}$ in the presence of a horseshoe kidney Case reports

Samenvatting en Conclusies

CHAPTER 12 Acknowledgements

Curriculum Vitae 
CHAPTER 1

GENERAL INTRODUCTION 


\section{INTRODUCTION}

The horseshoe kidney is a congenital malformation with an incidence of one in 600 to $800^{\prime}$. Although the cause of this anomaly is not known with certainty, some remarkable discoveries have been made. Horseshoe kidneys have been found as part of the luxate syndrome caused by the presence of a single mutant gene in the mouse $\mathrm{e}^{2.3}$. It has further been proven that maternal vitamin A deficiency during pregnancy may cause the development of a horseshoe kidney in the rat ${ }^{4}$. However, it is not known if this is also applicable for the human setting. Some authors found that the horseshoe kidney may occur familial in the human being ${ }^{57}$. Because of the low incidence of horseshoe kidneys it is hard to obtain enough data for research on the causes of the horseshoe kidney or other subjects regarding this congenital malformation. Still, quite a few aspects of the horseshoe kidney have been studied, or at least reported. The urological consequences of the horseshoe kidney have already been published by Gutierrez in $1931^{\circ}$. Transplantation of horseshoe kidneys is considered due to the organ shortage. Finally, aortic aneurysm repair can be complicated by an overlying horseshoe kidney.

\section{UROLOGICAL CONSEQUENCES OF THE HORSESHOE KIDNEY}

The horseshoe kidney itself does not produce symptoms and is sometimes discovered by coincidence. Symptoms of a diseased horseshoe kidney are often caused by ureteropelvic junction obstruction. The preferred method to diagnose the horseshoe kidney is excretory urography, computed tomography or ultrasound ${ }^{1.912}$. Ultrasound also gives the possibility to diagnose this congenital malformation in the fetus ${ }^{1315}$. In some cases when these diagnostic modalities are not conclusive, renal nuclear scanning is advised by some authors ${ }^{1618}$.

Horseshoe kidneys are often associated with other congenital anomalies. Organ systems most commonly involved include the skeletal, cardiovascular, and central nervous system. Horseshoe kidneys may also be observed in patients with trisomy-18 and Turner's syndrome $^{192}$.

Renal malignancies have also been described to be associated with horseshoe kidneys ${ }^{2}$. Carcinoid tumors and Wilms' tumors seem to have a higher incidence in horseshoe kidneys than in kidneys with a normal anatomy in the general population ${ }^{2427}$. These malignancies have never been reported to occur after transplantation of a horseshoe kidney.

Two thirds of the horseshoe kidneys present themselves through complications, such as recurrent urinary tract infections, renal calculi and hydronephrosis ${ }^{23.50}$. A variety of surgical techniques for the treatment of these complications have been described and all aim at improving urine outflow through the uretero pelvic junction. The AndersonHynes pyeloplasty ${ }^{31.32}$ endopyelotomy ${ }^{13.37}$ and ureterocalycostomy ${ }^{33+2}$ have been used to treat the ureteropelvic junction obstruction in horseshoe kidneys.

The Anderson-Hynes pyeloplasty is a modified dismembered pyeloplasty ${ }^{31.32}$. After excision of the ureteropelvic junction, the ureter is spatulated on its lateral aspect.

Reduction of a redundant portion of the pelvis is performed and the spatulated ureter is anastomosed to a lower aspect of the pelvis, creating a more dependent drainage.

To perform an endopyelotomy a stent catheter is placed across the ureteropelvic junction in a retrograde fashion, after which a nephroscope is introduced into the renal pelvis. Through the nephroscope a hook knife is passed for a full thickness incision of the ureteropelvic junction. Using an angioplasty balloon the ureteropelvic junction is then dilatated to ensure that the incision is deep and long enough to correct the obstruction. Finally the stent catheter is left in situ ${ }^{30}$. 
Ureterocalycostomy involves the anastomosis of the ureter to the lower pole calyx. The ureter is transected below the ureteropelvic junction and spatulated. The ureteropelvic junction is resected with nearly the entire pelvis. After identification of the lower pole calyx, the renal capsule and parenchyma are incised. The ureter is then anastomosed to the calyx over a JJ stent, creating a dependent drainage ${ }^{3 s \cdot a}$.

Heminephrectomy may be indicated when a horseshoe kidney is complicated by severe hydronephrosis. This operation can also be performed laparoscopically ${ }^{645}$. After obtaining laparoscopic access to the peritoneal cavity and transperitoneal exposition of the horseshoe kidney, the renal arteries and veins and also the ureter of the diseased side are identified and divided. The renal isthmus is then exposed and divided using a haemostatic technique such as endostaplers or a coagulator. Finally the split horseshoe kidney is delivered.

\section{KIDNEY TRANSPLANTATION, SURGICAL TECHNIQUE}

The kidney is placed retroperitoneally in the iliac fossa*t. After a curvilinear incision is made from a few centimeters above the pubic symphysis to approximately $4 \mathrm{~cm}$ medial to the anterior superior iliac spine, the muscles are divided and dissected in layers. Care should be taken not to open the peritoneum. The iliac artery and vein are now identified and vascular control is obtained. The iliac vessels are then cross-clamped. The kidney is removed from the ice and the ideal place for the arterial and venous anastomosis is determined. After making a venotomy, which is size matched with the renal vein of the graft, the renal vein is anastomosed end-to-side to the iliac vein, using running sutures. The length of the renal vein should be matched to that of the renal artery, avoiding kinking of the vessel.

The arterial anastomosis usually is an end-to-side anastomosis between the renal artery of the graft and the common iliac artery or the external iliac artery of the recipient. An endto-end anastomosis between the renal artery and the hypogastric artery is performed by some surgeons. When present, the aortic patch on the renal artery is used to perform the anastomosis. Usually the anastomosis is made using a running suture, although in severe atherosclerosis of the vascular system of the recipient, it can be necessary to use interrupted sutures.

When the arterial anastomosis is ready, the clamps are released. The kidney should change colour from pale to dark red quickly. The time that elapsed between the moment the kidney was removed from the ice and the moment the clamps are released is known as the second warm ischaemic time and should be kept to a minimum.

After controlling of any bleeding around the anastomosis, the bladder is mobilised and the muscle is divided until the mucosa appears. The mucosa is opened and the spatulated distal ureter is anastomosed to the bladder mucosa. The muscle layers are then closed over the ureter. A stent can be placed in the ureter, but this is not advised by all transplant surgeons.

Finally haemostasis should be checked carefully and a suction drain is placed into the retroperitoneum and the wound is closed in layers. 


\section{THE ORGAN SHORTAGE}

Since the introduction of haemodialysis in $1945^{\circ}$, short-term treatment of acute renal failure has been possible and was gradually resulting in chronic haemodialysis. Because of the high morbidity and mortality and the low quality of life, haemodialysis is not the treatment of choice for patients with end-stage renal failure. Patients who receive a kidney transplant have a lower morbidity and mortality than patients who are on prolonged haemodialysis, especially since the new immunosuppressive drugs ${ }^{4.6}$. The improvement in the quality of life is impressive. Renal transplantation is also less expensive then prolonged dialysis ${ }^{\circ}$. Therefore, the preferred treatment for patients with end-stage renal failure is renal transplantation. With the increase in experience and the improving results of kidney transplantation, the indications for transplantation were widened. This caused an increase in the number of patients on the waiting list for a kidney transplantation. Figure 1.1 shows the discrepancy between the number of patients on the waiting list and the number of patients who received a cadaveric renal allograft. Today, most kidneys used for transplantation are procured from braindead donors. However, several alternatives have been proposed to increase the number of kidneys available for transplantation.

To make living donation more inviting to the donor and to decrease morbidity, laparoscopic donor nephrectomy was initiated ${ }^{51 / 54}$. The approach used was either transperitoneal or retroperitoneal ${ }^{535}$. Although in both methods the number of postoperative complications reported in the donor decreased, in most centers laparoscopic live donor nephrectomy is still not accepted as the standard surgical approach to living donation.

Another alternative that enjoys an increasing popularity in a lot of countries is non-heartbeating donation ${ }^{606}$. In this method of donation the kidneys are procured from donors in whom death was determined by cardiac criteria instead of neurological criteria, hence the name non-heartbeating. To reduce ischaemic damage to the kidneys after the circulation has arrested, several techniques are being used. Most common is the in-situ-preservation technique, in which the kidneys are cooled inside the body of the donor, before the explantation is started ${ }^{6}$. For this purpose a special Double-Balloon-Triple-Lumen catheter is inserted into the aorta via the femoral artery, after the cardiac arrest. Other, less popular methods, are the normothermic recirculation and total body cooling techniques. In both techniques a cardiopulmonary bypass is used to maintain normal body temperature and oxygenation or cooling of the body, respectively ${ }^{65}$.

With the rise of non-heartbeating donation, viability assessment of kidneys became increasingly necessary to guarantee a good quality. Machine perfusion proved to be a superior method of preservation over cold storage and provided the possibility of viability testing $^{66.6}$. The value of (alpha) glutathione-S-transferase, an enzyme released by ischaemically damaged proximal tubular cells, in the perfusate of machine perfused kidneys can roughly predict posttransplant outcome $\mathrm{e}^{6 \mathrm{s.69}}$.

The en bloc transplantation of paediatric kidneys into adult recipients has been described by a number of authors ${ }^{207}$. After the kidneys are explanted en bloc, the proximal aorta and vena cava inferior are closed. The distal parts of both vessels are anastomosed end-to-side to the iliac vessels of the recipient, using a running suture. In order to prevent late hypertension caused by relative renal artery stenosis due to prohibited growth of the anastomosis site, some authors prefer to use interrupted sutures when anastomosing the donor aorta to the recipient iliac artery ${ }^{3}$. The ureters are implanted into the bladder separately. When the ureters are very short, a Boari implantation technique can be used". 


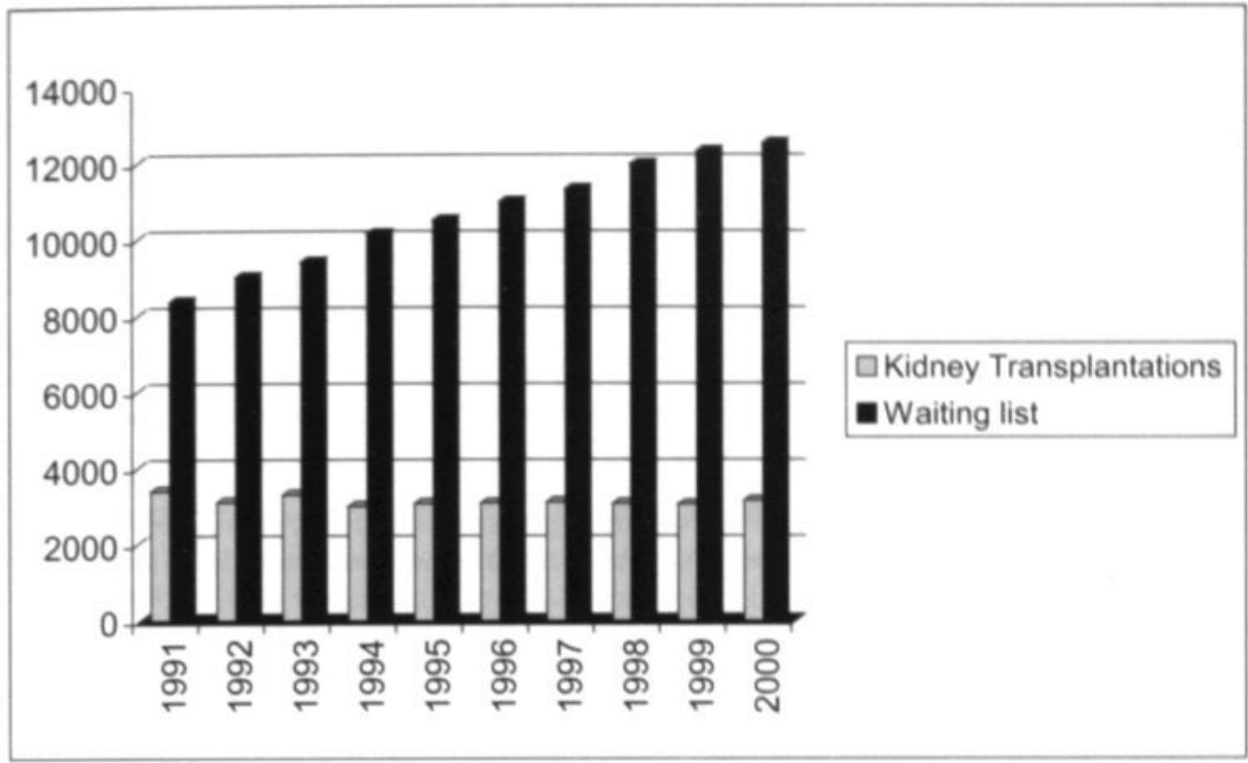

Figure 1.1:

Dynamics of the Eurotransplant kidney waiting list and cadaveric donor transplants of the past 10 years. The waiting list is given at December 31 of each year. (Source: Eurotransplant International Foundation. Annual Reports 1996-1999, Eurotransplant International Foundation. Preliminary Data 2000).

Elderly donors are also more frequently used for transplantation. The Eurotransplant Senior Programme, also known as the "old for old" programme gives elderly patients with end stage renal failure the possibility of renal transplantation ${ }^{7.7}$. Kidneys procured from donors over the age of 65 years are transplanted into recipients of the same age group. Because the percentage of glomerulosclerosis increases with age ${ }^{x / \%}$, it has been proposed to use the nephron mass instead of the donor age as the decisive criterion in the transplantation of kidneys from elderly donors. Depending on the number of nephrons these kidneys will be either transplanted separately or en bloc into one recipient ${ }^{200}$. Because the upper age limit is no longer relevant according to this theory, an increase of the number of donors is to be expected.

Although some authors believe that xenotransplantation, the transplantation of organs procured from a different species, is the future treatment of organ failure ${ }^{n-10}$. there are still a lot of hurdles to be overcome, for instance in graft rejection, microbial contamination and ethics.

An unwanted effect of the organ shortage is commerce in transplant organs ${ }^{* 0 n}{ }^{n}$. This is not only limited to living unrelated donation, where the donor sells one kidney to the recipient. In some countries, such as the People's Republic of China, the organs of executed prisoners are sold to recipients from other countries ${ }^{n}$. Due to the lack of control over these transplantations the quality is often below standards" ${ }^{n}$. Although legislation in most European countries forbids commerce in organs, pleads against these laws are heard with some regularity". The shortage of kidney donors in the Philippines has led to the proposal of the government for controlled trade in kidneys" ${ }^{n}$, a situation that already exists in Iran. 


\section{VASCULAR SURGERY}

Horseshoe kidneys are known to complicate vascular surgery, especially aortic aneurysm repair ${ }^{*}$. With the modern diagnostic modalities the horseshoe kidney is usually diagnosed in advance of any operation. However in the acute event of a ruptured aortic aneurysm, the vascular surgeon can be surprised by the presence of a horseshoe kidney. This will influence the decisions on the approach. In some published cases it was even thought impossible to exclude the aneurysm due to the overlying renal isthmus and the high number of renal arteries ${ }^{* \cdot n}$.

\section{AIM OF THE THESIS}

Although horseshoe kidneys are quite rare, they are offered for transplantation with some regularity. Approximately $30 \%$ of the horseshoe kidneys are discarded, because of reluctance to use them for transplantation. This reluctance is often based on unfamiliarity and inexperience. Results of horseshoe kidney transplantation had never been published and a decision cascade to guide the inexperienced transplant surgeon was not available. Therefore bad posttransplant results, caused by technical difficulties during the transplantation, are feared by some transplant surgeons.

An aortic aneurysm in the presence of horseshoe kidney may warrant a different surgical approach, depending on the aneurysm (asymptomatic or ruptured) and the vascular anatomy of the horseshoe kidney. Because the combination of a horseshoe kidney with an aortic aneurysm is not seen frequently, there is not much knowledge of the ideal approach to this problem.

This thesis consists of retrospective and literature studies that aim at: (1) giving the posttransplant results of horseshoe kidney transplantation, (2) providing a guideline for the transplantation of horseshoe kidneys and (3) aortic aneurysm repair in the presence of a horseshoe kidney. The retrospective work was performed using data from transplant centers in 22 different countries. 


\section{References}

1. Bauer SB. Anomalies of the kidney and ureteropelvic junction. In: Walsh PC, Retik AB, Vaughan ED Jr, Wein AJ. eds. Campbell's urology. Philadelphia: WB Saunders, 1998: 1708-57.

2. Cartel TC. The genetics of luxate mice. Chapter III. Horseshoe kidney, hydronephrosis and lumbar reduction. J Genetics 1953: 51: 441-57.

3. Cartel TC. The genetics of luxate mice. Chapter IV. Embryology. J Genetics 1954: 52: 1-28.

4. Wilson JG, Warkany J. Malformations in the genito-urinary tract induced by maternal vitamin A deficiency in the rat. Am J Anat 1948: 83:357-407.

5. Bridge RAC. Horseshoe kidneys in identical twins. Br J Urol 1960:32: $32-3$.

6. Boatman DL. Hawtrey CE. Familial horseshoe kidney. J lowa Med Soc 1973: 63: 399-401.

7. David RS. Horseshoe kidney: a report of one family. Br Med J 1974: 4: 571-2.

8. Gutierrez R. The clinical management of the horseshoe kidney. New York: PB Hoeber, 1934.

9. Jenss H. Schulze K. Klott KL. Hufeisenniere - ist sonographisch die Diagnose möglich? Fortschr Rontgenstr 1980: $133: 71-4$.

10. Nguyen KT. Downey M. Gutelius J. An unusual case of horseshoe kidney: CT appearance. Can Assoc Radiol J 1989: 40: 320-1.

11. Banerjee B, Brett I. Ultrasound diagnosis of horseshoe kidney. Br J Radiol 1991; 64: 898-900.

12. Strauss S, Dushnitsky T. Peer A. Manor H. Libson E. Lebensart PD. Sonographic features of horseshoe kidney: review of 34 patients. J Ultrasound Med 2000; 19: 27-31.

13. Sherer DM. Cullen JB. Thompson HO, Metlay LA. Woods Jr JR. Prenatal sonographic findings associated with a fetal horseshoe kidney. J Ultrasound Med 1990: 9:477-9.

14. King KI. Kofinas AD. Simon NV, Clay D. Antenatal ultrasound diagnosis of fetal horseshoe kidney. J Ultrasound Med 1991: 10:643-4.

15. Kovo-Hasharoni M. Mashiach R, Levy S, Meizner I. Prenatal sonographic diagnosis of horseshoe kidney. J Clin Ultrasound 1997: 25: 405-7.

16. LaManna MM. Coll ME, Karafin LJ, Parker JA. The radionuclide diagnosis of horseshoe kidney. Clin Nucl Med 1985: 10: 799-803.

17. Grandone CH. Haller JO. Berdon WE. Friedman AP. Asymmetric horseshoe kidney in the infant: value of renal nuclear scanning. Radiology 1985; 154: 366.

18. Kumar A. Pham DH. Meindok H. Aggarwal S. Diagnosis of horseshoe kidney on Technetium-99m hepatobiliary scintigraphy. Clin Nucl Med 1993; 18:243-4.

19. Zondek LH. Zondek T. Horseshoe kidney and associated congenital malformations. Urol Int 1964: 18:347.56.

20. Boatman DL, Kolln CP. Flocks RH. Congenital anomalies associated with horseshoe kidney. J Urol 1972: $107: 205-7$.

21. Segura JW. Kelalis PP. Burke EC. Horseshoe kidney in children. J Urol 1972: 108: 3336.

22. Grainger R, Lane V, Murphy DM. Horseshoe kidney: a review of the presentation, associated congenital anomalies and complications in 73 patients. Irish Medical Journal 1983: 76:315-7.

23. Rubio Briones J. Regalado Pareja R. Sánchez Martin F, Chéchile Huguet Pérez J. Villavicencio Mavrich H. Incidence of tumoural pathology in horseshoe kidneys. Eur Urol 1998: 33: 175 -9.

24. Mesrobian HG, Kelalis PP. Hrabovsky E. Othersen Jr HB. deLorimier B. Wilms tumor in horseshoe kidneys: a report from the National Wilms Tumor Study. J Urol 1985: 133: 1002-3.

25. Nirgiotis JG, Black CT. Sherman JO. Wilms' tumor in horseshoe kidney: presentation due to ureteropelvic junction obstruction.J Surg Oncol 1991: 48: 210-2.

26. Lal A. Marwaha RK. Narshimhan KL. Yadav K. Wilms' tumor arising in a horseshoe kidney. Indian Pediatr 1995: 32: 689-93.

27. Krishnan B. Truong L.D. Saleh G. Sirbasku DM. Slawin KM. Horseshoe kidney is associated with an increased relative risk of primary renal carcinoid tumor.J Urol 1997: 157: 205966.

28. Glenn JF. Analysis of 51 patients with horseshoe kidney. New Eng J Med 1959: 261:6847.

29. Kilpatrick FR. Horseshoe kidneys. Proc R Soc Med 1967: 60: 433-8 
30. Kolln CP. Boatman DL, Schmidt JD. Flocks RH. Horseshoe kidney: a review of 105 patients. J Urol 1972: $107: 203-4$.

31. Novick AC, Streem SB. Surgery of the kidney. In: Walsh PC. Retik AB, Vaughan ED Jr, Wein AJ, eds. Campbell's urology. Philadelphia: WB Saunders, 1998: 3041-50.

32. Dewan PA, Ashwood PJ. Pelviureteric junction obstruction: age of presentation versus pathology. J Paed Child Health 1998: $34: 3846$.

33. Salas M, Gelet A, Martin X, Sanseverino R, Viguier JL. Dubernard JM. Horseshoe kidney: the impact of percutaneous surgery. Eur Urol 1992: 21: 1347.

34. Nakamura K, Baba S. Tazaki H. Endopyelotomy in horseshoe kidneys. J Endourology 1994; 8: $203-6$.

35. Keeley Jr FX, Bagley DH, Kulp-Hugues D, Gomella LG. Laparoscopic division of crossing vessels at the ureteropelvic junction. J Endourology 1996; 10: 163-8.

36. Bellman GC, Yamaguchi R. Special considerations in endopyelotomy in a horseshoe kidney. Urology 1996; $47: 5826$.

37. Pozniak MA. Nakada SY. Three-dimensional computed tomographic angiography of a horseshoe kidney with ureteropelvic junction obstruction. Urology 1997; 49: 267-8.

38. Jameson SG. McKinney JS, Rushton JF. Ureterocalyostomy: a new surgical procedure for correction of uretero pelvic stricture associated with an intrarenal pelvis. J Urol 1957: 77: 135-43.

39. Hawthorne NJ. Zincke H. Kelalis PP. Ureterocalicostomy: an alternative to nephrectomy. J Urol 1976: 115:583-5.

40. Mollard P. Brauw P. Primary ureterocalycostomy for severe hydronephrosis in children.J Pediatric Surg 1980; 15:87-91.

41. Mollard P. Mouriquand P. Joubert P. Pouyau A. Urétéro-calicostomie pour hydronéphrose par maladie de la jonction de l'enfant et adolescent. Chir Pédiatr 1990; 31: 87-91.

42. Dewan PA. Clark S, Condron S. Henning P. Ureterocalycostomy in the management of pelvi-ureteric junction obstruction in the horseshoe kidney. Br J Urol 1999; 84: 366-8.

43. Riedl CR. Huebner WA. Schramek P. Pflueger H. Laparoscopic hemi-nephrectomy in a horseshoe kidney. Br J Urol 1995: 76: 140-1.

44. Donovan JF, Cooper CS, Lund GO. Winfield HN. Laparoscopic nephrectomy of a horseshoe kidney. J Endourology 1997: 11: 181-4.

45. Hayakawa K, Baba S. Aoyagi T. Ohashi M. Ishikawa H. Hata M. Laparoscopic heminephrectomy of a horseshoe kidney using microwave coagulator. J Urol 1999: 161: 1559.

46. Forsythe JLR. Kidney transplantation. In: Forsythe JLR. ed. Transplantation surgery. London: WB Saunders, 1997: $123-46$.

47. Kolff WJ. De kunstmatige nier. Thesis, University of Groningen, 1946.

48. Waiser J. Budde K, Schreiber M. Peibst O. Koch U. Bohler T. Hoffken B, Hauser I. Neumayer HH. The quality of life in end stage renal disease care. Transpl Int 1998: 11 Suppl 1: S42-5.

49. Schnuelle P. Lorenz D. Trede M. van der Woude FJ. Impact of renal cadaveric transplantation on survival in end-stage renal failure: evidence for reduced mortality risk compared with hemodialysis during long-term follow-up. J Am Soc Nephrol 1998; 9: 2135-41.

50. Karlberg I, Nyberg G. Costeffectiveness studies of renal transplantation. Int J Technol Assess Health Care 1995; $11: 611-22$.

51. Schulam PG. Kavoussi LR. Cheriff AD, Averch TD, Montgomery R. Moore RG. Ratner LE. Laparoscopic live donor nephrectomy: the initial 3 cases. J Urol 1996: 155: 1857-9.

52. Ratner LE, Ciseck LJ. Moore RG. Cigarroa FG, Kaufman HS, Kavoussi LR. Laparoscopic live donor nephrectomy. Transplantation 1995; 60: 1047-9.

53. Nogueira JM. Cangro CB. Fink JC, Schweitzer E, Wiland A. Klassen DK, Gardner J. Flowers JL, Jacobs S, Cho E. Philosophe B. Bartlett ST. Weir MR. A comparison of recipient renal outcomes with laparoscopic versus live donor nephrectomy. Transplantation 1999; 67: 722-8.

54. IJzermans JNM. Berends FJ, van Riemsdijk IC. Weimar W. Bonjer HJ. Laparoscopische donornefrectomie bij familieniertransplantaties: gunstige eerste ervaringen. Ned Tijdschr Geneesk 1999: 143: 942-5.

55. Ratner LE, Kavoussi LR. Sroka M. Hillier J. Weber R. Schulam PG. Montgomery R. Laparoscopic assisted live donor nephrectomy: a comparison with the open approach. Transplantation 1997: 63: 229.33.

56. Ratner LE, Kavoussi LR, Schulam PG. Bender JS. Magnuson TH. Montgomery R. Comparison of laparoscopic live donor nephrectomy versus the standard open approach. Transpl Proc 1997: 29: 138-9.

57. Flowers JL. Jacobs S. Cho E. Morton A. Rosenberger WF. Evans D. Imbembo AL. Bartlett ST. Comparison of open and laparoscopic live donor nephrectomy. Ann Surg 1997: 226: 483-90. 
58. Yang SC, Park DS, Lee DH. Lee JM. Park K. Retroperitoneal endoscopic live donor nephrectomy: report of 3 cases. JUrol 1995: $153: 18846$.

59. Ishikawa A. Suzuki K. Saisu K. Kageyama S, Ushiyama T. Fujita K. Endoscopy-assisted live donor nephrectomy: comparison between laparoscopic and retroperitoneoscopic procedures. Transpl Proc 1998: 30: $165-7$.

60. Kootstra G, van Hooff JP. In-situpreservatie van nieren bij "hartdode" donoren: mogelijkheden voor het ophef. fen van het tekort aan donornieren. Ned Tijdschr Geneesk 1998: 142: 2838-43.

61. Daemen JHC, de Wit RJ. Bronkhorst MWGA. Marcar ML. Yin M. Heineman E. Kootstra G. Short-term outcome of kidney transplants from non-heart-beating donors after preservation by machine perfusion. Transplant Int 1996: 9 Suppl 1: S76-80.

62. Wijnen RMH. Booster M. Speatgens C. Yin M. van Hooff JP. de Boer J. Kootstra G. Long-term follow-up of transplanted non-heart beating donor kidneys: preliminary results of a retrospective study. Transpl Proc 1993: $25: 1522.3$.

63. Wijnen RMH. Booster BM. Stubenitsky BM. de Boer J. Heineman E. Koostra G. Outcome of transplantation of non-heartbeating donor kidneys. Lancet 1995: 345: 1067-70.

64. Daemen JHC. Non-heart-beating kidney donors: clinical implications. Thesis, University Maastricht, 1998.

65. Valero R, Cabrer C, Oppenheimer F. Trias E, Sánchez Ibánez J. De Cabo FM. Navarro A, Paredes Zapata D. Alcaraz A. Gutiérrez R. Manyalich M. Normothermic recirculation reduces primary graft dysfunction of kidneys obtained from non-heart-beating donors. Transplant Int 2000; 13:303-10.

66. Booster MH. Yin M. Stubenitsky BM, Kemerink GJ, van Kroonenburgh MJPG. Heidendal GAK, Halders SGEA, Heineman E. Buurman WA. Wijnen RMH. Tiebosch ATM, Bonke H. Kootstra G. Beneficial effect of machine perfusion on the preservation of renal microcirculatory integrity in ischemically damaged kidneys. Transpl Proc 1993: 25: 30126.

67. Daemen JHC, de Vries B, Oomen APA. DeMeester J. Kootstra G. Effect of machine perfusion preservation on delayed graft function in non-heart-beating donor kidneys - early results. Transplant Int 1997: 10: 317.22.

68. Daemen JHC, Heineman E, Kootstra G. Viability assessment of non-heart-beating donor kidneys during machine perfusion. Transpl Proc 1995: 27: 2906-8.

69. Kievit JK. Nederstigt AP, Oomen APA. Janssen MA. Schoot L. Kootstra G. Release of alpha-Glutathione S. Transferase ( $\alpha G S T$ ) and pi-Glutathione S-Transferase ( $\pi$ GST) from ischemic damaged kidneys into the machine perfusate - relevance to viability assessment. Transpl Proc 1997; 29: 3591-3.

70. Hobart MG, Modlin CS, Kapoor A. Boparai N, Mastroianni B, Papajcik D. Flechner SM. Goldfarb DA, Fischer R. O'Malley KJ. Novick AC. Transplantation of pediatric en bloc cadaver kidneys into adult recipients. Transplantation 1998; 66: 1689-94.

71. Arrazola L., Sozen H. Humar A. Papalois V. Uknis M. Matas AJ. Kidney transplant using pediatric donors - effect on long-term graft and patient survival. Transpl Proc 2000; 32: 1839.

72 Pugliese MR, DuLuca J. Hollenbeck M, Grabensee B. Heering PJ. Outcome of renal transplants using cadaveric paediatric donors in three countries. Transpl Proc 1998: 30: 2280-2.

73. Petritsch PH. Colombo T. Wirnsberger GH, Zitta S, Ratschek M. Gute Langzeitfunktion von transplantierten Săuglingsnieren in Erwachsene. Acta Chir Austriaca 2000: 32 Suppl 170: S5.

74. Schlieper G, Ivens K, Voiculescu A. Luther B, Sandmann W, Grabensee B. Eurotransplant senior program "old for old": results from 10 patients. Clin Transplant 2001: 15: $100-5$.

75. B. Cohen. Balancing supply and demand in organ transplantation. Thesis, University Maastricht, 2001.

76. Brenner BM. Cohen RA, Milford EL. In renal transplantation, one size may not fit all.J Am Soc Nephrol 1992;3:1629.

77. Brenner BM, Mackenzie HS. Nephron mass as a risk factor for progression of renal disease. Kidney Int 1997; $52: 51247$.

78. Taal MW. Tilney NL. Brenner BM. Mackenzie HS. Renal mass: an important determinant of late allograft outcome. Transplantation reviews 1998; 12:74-84.

79. Halloran PF. Non-immunologic tissue injury and stress in chronic allograft dysfunction. Graft 1998: 1:25-9.

80. Lewis DM. Gorrie M. Bingham C. Nichols AJ. Beaman M. Riad HN. Elderly donors in renal transplantation: a worthwhile venture? Transpl Proc 1998: 30: 2279.

81. Andrés A. Morales JM. Herrero JC, Praga M. Morales E. Hernández E, Ortuno T, Rodicio JL. Martínez MA. Usera G. Diaz R. Polo G. Aguirre F. Leiva O. Double versus single renal allografts from aged donors. Transplantation 2000: 69: 2060-6.

82. Remuzzi G. Grinyò J. Ruggenenti P. Beatini M. Cole EH. Milford El. Brenner BM. Early experience with dual kidney transplantation in adults using expanded donor criteria. J Am Soc Nephrol 1999; 10:2591-8.

83. Hesse U.J.. Vermasse F. Lameire N. Vanholder R. Expanded criteria donors and dual kidney transplantation. Transpl Int 1998: 11: 457-8. 
84. Dafoe DC. Alfrey EJ. Dual renal grafts: expansion of the donor pool from an overlooked source. Transpl Int 1998: $11: 164-8$.

85. Dietl KH. Wolters HH. Marshall B, Heidenreich S, Schuermann G. Senninger N. One year experience in -Two in One" double kidney transplantation in marginal donors. Transplantationsmedizin 1998: 10: 191-201.

86. Lee CM. Scandling JD, Pavlakis M, Markezich AJ. Dafoe DC, Alfrey EJ. A review of the kidneys that nobody wanted. Transplantation 1998; 65: 213-9.

87. Soin B. Vial CM. Friend PJ. Xenotransplantation. Br J Surg 2000; 87: $138-48$.

88. Cozzi E, Masroor S, Soin B, Vial CM. White DJG. Progress in xenotransplantation. Clin Nephrol 2000: 53: $13-8$.

89. Gonwa TA. Transplantation. Am J Kidney Disease 2000: 35: S153-9.

90. Cohen B, Persijn GG. Vanrenterghem Y. Commerce in transplantation: how does it effect European legislation? Clin Transplant 2000; 14: 28-31.

91. Een nier voor een volkswagen. NRC Handelsblad, April 9, 2001.

92. China sells organs of slain convicts. The Observer, December 10, 2000.

93. Chien YS. Hsieh HH. Hsu KT. Clinical analysis of 100 renal transplant recipients back from the People's Republic of China to Taiwan. Transpl Proc 2000: 32: 1819-21.

94. Croughs B. Baas in eigen buik. HP de Tijd, March 2, 2001: 36-41.

95. Ona ET. Compensated organ donation: a Philippines experience. Fourth Congress of Nephrology. Urology and Transplantatoin of SAARC Countries. Karachi, Pakistan, February 9-11. 2001.

96. Bietz DS, Merendino KA. Abdominal aneurysm and horseshoe kidney: a review. Ann Surg 1975: 181: 333-41.

97. Julian OC. Diagnosis in arterial disease. Surg Clin North Am 1956; 36: $177-91$. 
Chapter 2

Anatomy and embryology 


\section{INTRODUCTION}

Most horseshoe kidneys show a fusion of the lower poles, forming a horseshoe shape with the concavity facing cranially. However, in an estimated 5\% of the horseshoe kidneys the upper poles have fused, forming a horseshoe with the concavity facing caudally ${ }^{15}$. A total fusion of the kidney, creating a "cake" kidney is considered extremely rare ${ }^{6 t}$. In order to understand the anatomy of a horseshoe kidney, knowledge of the embryological develop ment is essential.

\section{NORMAL KIDNEY DEVELOPMENT}

Three structures in the urinary system appear successively. The first structure to appear is the pronephros. It is formed from mesodermal cells of the intermediate cell mass in the cervical region and consists of several tubules. By the end of the fourth week, before it reaches a functional state, the pronephros has already disappeared.

The mesonephros is formed of mesodermal cells in the thoracic and lumbar region. Like the pronephros it consists of several tubules. However, in contrast to the pronephros, glomeruli also develop in the mesonephros, leading to a functional state. The mesonephros reaches its maximum degree of development in the second month, after which it gradually degenerates in a cranio-to-caudal direction.

The metanephros or permanent kidney develops from two sources: The ureteric bud from the mesonephric duct and the metanephrogenic cap from the intermediate cell mass of the lower lumbar and sacral regions. Whereas the ureteric bud forms both the ureter, its pelvis and the major calyces, the mesocèrmar lerl's ur ftkenetanephongenic cap eventually produce the glomerular capsules, proximal and distal convoluted tubules and the loops of Henle.

As normal development proceeds, the kidneys rotate medially and gradually "ascend" along the posterior abdominal wall. This so-called ascent is mainly caused by the growth of the body in the lumbar and sacral regions and by the straightening of its curvature. The kidneys reach their final position at the level of the second lumbar vertebra. At successive higher levels during its "ascent" the kidney is vascularized by successive higher branches of the aorta?.

\section{HORSESHOE KIDNEY DEVELOPMENT}

A horseshoe kidney is the result of an accidental fusion of the metanephrogenic caps of both sides. This fusion occurs between the fourth and sixth week of gestation resulting in an isthmus that usually consists of renal parenchyma. There are different theories as to the cause of the fusion of both metanephrogenic caps. These theories can be divided into two groups. The first theory is based on mechanical conceptions. The fusion is explained by a converging course taken by the ureteric buds ${ }^{10}$, or by the relation of the metanephrogenic caps to the umbilical arteries. The latter causes the metanephrogenic caps of both sides to approach each other and finally touch and fuse when they rise between the umbilical arteries ${ }^{11.12}$. A completely different theory poses that cells from the posterior nephrogenic area form the parenchymatous isthmus after an abnormal migration".

The relative ascent of the horseshoe kidney is arrested by the renal isthmus that hooks behind the inferior mesenteric artery, giving it a lower than normal position (figure 2.1). Because the fusion of the metanephrogenic caps occurs before the kidneys make their medial rotation, the pelvices of the horseshoe kidney face ventrally. Primitive renal vessels are often retained. This gives the horseshoe kidney an often very complex vascular anatomy. 
Two types of fusion are recognized: midline fusion and lateral fusion of the renal units. As opposed to midline fusion, in lateral fusion the calyceal system may drain a portion of the kidney that extends across the midline ${ }^{1}$. Fusion of the calyceal systems of both sides would be possible if the ureteric buds would fuse during embryological development. Although this theory has been posed, it has never been reported in literature.

The isthmus connecting the lower poles usually contains functional parenchyma. In $15 \%$ of the horseshoe kidneys however, the isthmus is a fibrous band". The horseshoe kidney is situated lower than normal in the retroperitoneum. The renal isthmus usually crosses the L3 or L4 vertebra. Some horsehoe kidneys cross the midline even lower, at the level of the sacral promontory. This lower than normal position makes a horseshoe kidney particularly prone to trauma ${ }^{15.16}$. The renal isthmus usually lies in front of the aorta and the vena cava inferior. It rarely crosses behind them ${ }^{\text {" }}$ and even more infrequently between them". However, these observations make the theory of the cell migration in the development of the renal isthmus of the horseshoe kidney more probable. The suprarenal glands reach their position independently of the kidneys. This results in a cranial position of the suprarenal glands to the upper poles of the horseshoe kidney without making contact to them.

The pyela of the horseshoe kidney show a great variation in anatomy. There are generally two pyela, although variations with up to four pyela in different positions have been described'. The ureters can also vary in number and position. They normally course ventral to the renal isthmus, but they have also been described to course dorsal to the isthmus, or even directly originating from the isthmus ${ }^{1}$. Embryologically this is difficult to explain because the fusion must occur well before rotation takes place. The ureters usually insert high on the renal pelvis and course to the bladder under a sharp angle. This is thought to be the cause of ureteropelvic junction obstruction that often occurs?.

Horseshoe kidneys typically show a great variation in origin, number and size of the renal arteries and veins. The renal isthmus frequently has its own blood supply, often originating from the iliac arteries. Only $30 \%$ of all horseshoe kidneys posses a single renal artery and vein to each side ${ }^{14.19}$. Attempts have been made to classify the horsehoe kidneys by their vascular anatomy ${ }^{19.20}$, but frequent occurring variations in anatomy preclude a proper classification. 

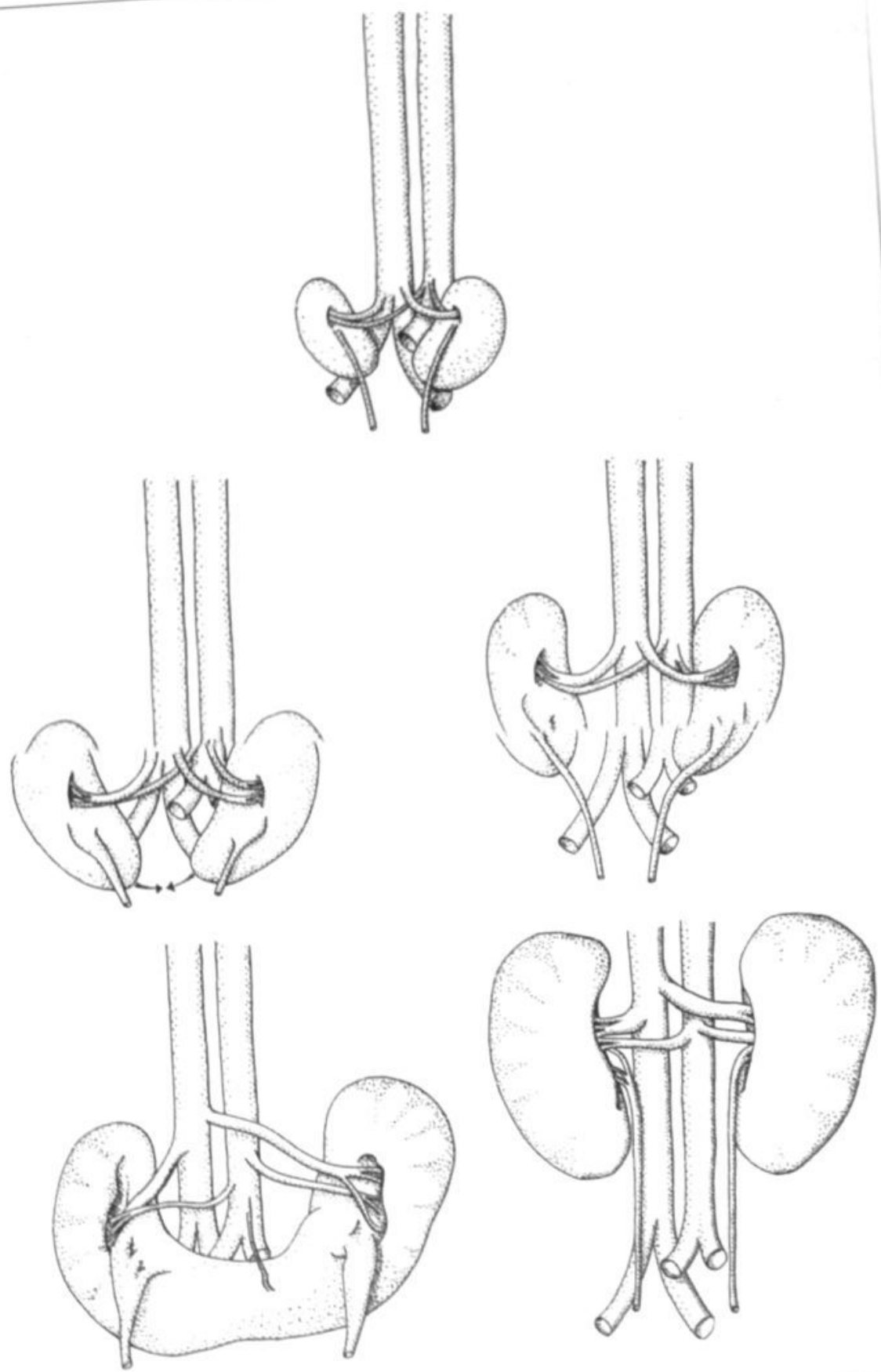

FIGURE 2.1: Embryological development of the horseshoe kidney (left) in comparison to normal kidney development (right). The inferion University Hospital Maastricht) (Illustrations by B. Eggen, Medical Illustration. 


\section{References}

1. Gutierrez R. The clinical management of the horseshoe kidney. Hoeber PB ed. New York: 1934.

2. Kolln CP. Boatman DL. Schmidt JD, Flocks RH. Horseshoe kidney: A review of 105 patients. J Urol 1972: $107: 2034$.

3. Pitts jr. WR, Muecke EC. Horseshoe kidneys: A 40-year experience.J Urol 1975; 113: $743-6$.

4. Culp OS, Winterringer JR. Surgical treatment of horseshoe kidney: Comparison of results after various types of operations. J Urol 1955; 73: 747-56.

5. Thompson AR. Guy's Hosp Rep 1929: 79: 201.

6. McLoughlin MG, Gardner TJ. Melville WG. Cake kidney with abdominal aneurysm. Can J Surg 1978: $21: 367$.

7. Srivastava RN. Singh M. Ghai OP, Sethi U. Complete renal fusion ("cake"/"lump" kidney). Br J Urol 1971:43;3914.

8. Shiller WA. Wiswell OB. A fused pelvic (cake) kidney. J Urol 1957; 78:9-16.

9. Moore KI. The developing human. Toronto: WB Saunders, 1988: 246-57.

10. Ninfo G. Sacral ectopy of the left kidney. Acta Chir Ital 1956: 12:466-73.

11. Boyden EA. Description of a horseshoe kidney associated with left inferior vena cava and discshaped suprarenal glands. together with a note on the occurrence of horseshoe kidneys in human embryos. Anat Rec 1931: 51: 187-212.

12. Zondek T. Notes on the topography of the foetal horseshoe kidney. Br J Urol 1952: 24: $201-6$.

13. Doménech Mateu JM, Gonzalez Compta X. Horseshoe kidney: A new theory on its embryogenesis based on the study of a 16-mm human embryo. Anat Rec 1988; 222:408-17.

14. Farman F. Fusion anomalies of the kidney. In: Alken CE, Dix VW, Goodwin WE, Weyrauch HM, Wildbolz E eds. Encyclopedia of urology, Vol.VIII. New York: Springer-Verlag. 1968: 66-72.

15. Kilpatrick FR. Horseshoe kidneys. Proc R Soc Med 1967; 60: 433-8.

16. Murphy JT, Borman KR. Dawidson I. Renal autotransplantation after horseshoe kidney injury: A case report and literature review. J Trauma 1996; 40: 840 .

17. Dajani AM. Horseshoe kidney: A review of twenty-nine cases. $\mathrm{Br}$ J Urol 1966: 37: 388-402.

18. Lowsley OS. Surgery of the horseshoe kidney. J Urol 1952: 67: 565-78.

19. Boatman DL, Cornell SH, Kolln CP. The arterial supply of horseshoe kidneys. Am J Roentgenology Radium Therapy and Nuclear Medicine 1971: 113: 447-51.

20. Graves FT. The arterial anatomy of the congenitally abnormal kidney. Br J Surg 1969; 56:533-41. 
$\underline{22}$

兽 
CHAPTER 3

\section{HORSESHOE KIDNEYS}

\section{IN HISTORICAL PERSPECTIVE}

O.B. Stroosma, T.W.M. van de Wiel,

G.W.H. Schurink, G. Kootstra

Submitted for publication 


\section{INTRODUCTION}

"The history of the horseshoe kidney is as ancient as creation itself, since it has its very origin in an embryological congenital malformation" [Gutierrez]'.

The horseshoe kidney is a fusion anomaly which occurs during the fourth to sixth week of gestation. Although it has a low incidence of one in 600 to 800 , its consequences on human health and medicine have been described from the middle ages up to the present time.

Gutierrez divided the history of the horseshoe kidney into three distinct eras': The early days of medicine and cadaveric observation when the horseshoe kidney was seen as a rare anatomical curiosity, the era in which the horseshoe kidney was accidentally discovered at abdominal operations without therapeutical consequences and the third era in which the horseshoe kidney was diagnosed and operations upon the horseshoe kidney were performed. A fourth era can be added: transplantation of horseshoe kidneys.

\section{THE FIRST ERA}

In this era all reports of horseshoe kidneys by many early anatomists were descriptions of post mortem examinations without clinical significance.

The first horseshoe kidney was documented by Jacopo Berengario da Carpi in the year 1522 (figure 3.1). Born in ca. 1460 in Carpi, north of Modena, he obtained his degree as magister in 1489 in Bologna, where he became a successful physician. In 1522 he published the Lragogae breves (Introduction to Anatomy). a concise account of the human body and a fine specimen of the Italian, pre-Vesalian, anatomy ${ }^{2}$. In the chapter about the kidneys he described a post-mortem examination in the public autopsy hall in Bologna:

"In 1521 I saw, myself, in our school in Bologna at a public dissection one of the emulgents", an artery, making a duct on the right on the outside of the kidney which went to the ureteric duct coming from the above-mentioned kidney. Both went within one channel to the bladder. However, that artery also entered the kidney in the usual place. In this individual the kidneys were continuous as if they were one kidney. He had two emulgent veins and two emulgent arteries. And two ureteric ducts, with only one enveloping panniculus which occupied the normal places of the kidneys, in the midline the part of the back which is between and below the spleen and the liver." 


\begin{abstract}
iF

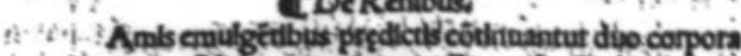

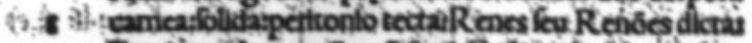

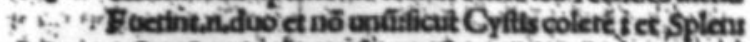

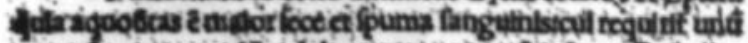

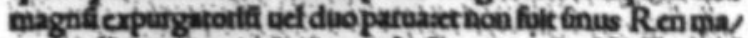

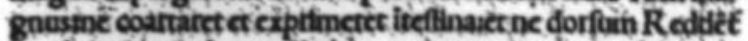

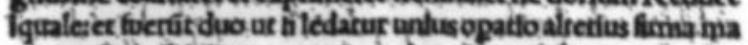

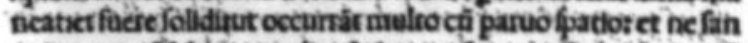

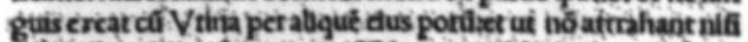

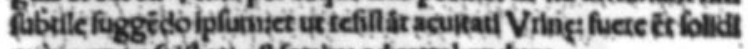
quì corpus fpillum eft fottus ad attrahendume

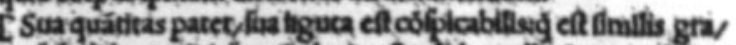

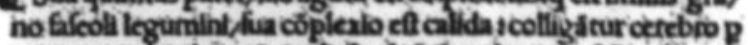

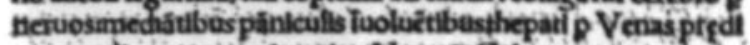
ctascoordl p mighias ArteliasiNotatit Galmagnasarterlas in

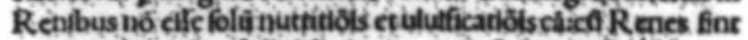
parua mébrazg bus fufficlcbat pua ancilated tncts funt inagne

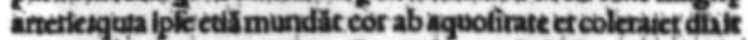
ctisimultodics. A orta trahit a flomacho $c t$ ab itceflints anguiné

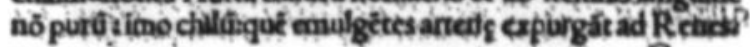

First know documentation of a horseshoe kidney by Jacopo Berengario da Carpi, printed in the Isagagae breves in the year 1522. (Source: Berenger da Carpi. Isagoge breves perlucide ac uberrime in anatomiam humani corporis. Bologne: per Benedictum Hectoris, 1522.) Courtesy of the University Library of Pisa, Italy. 


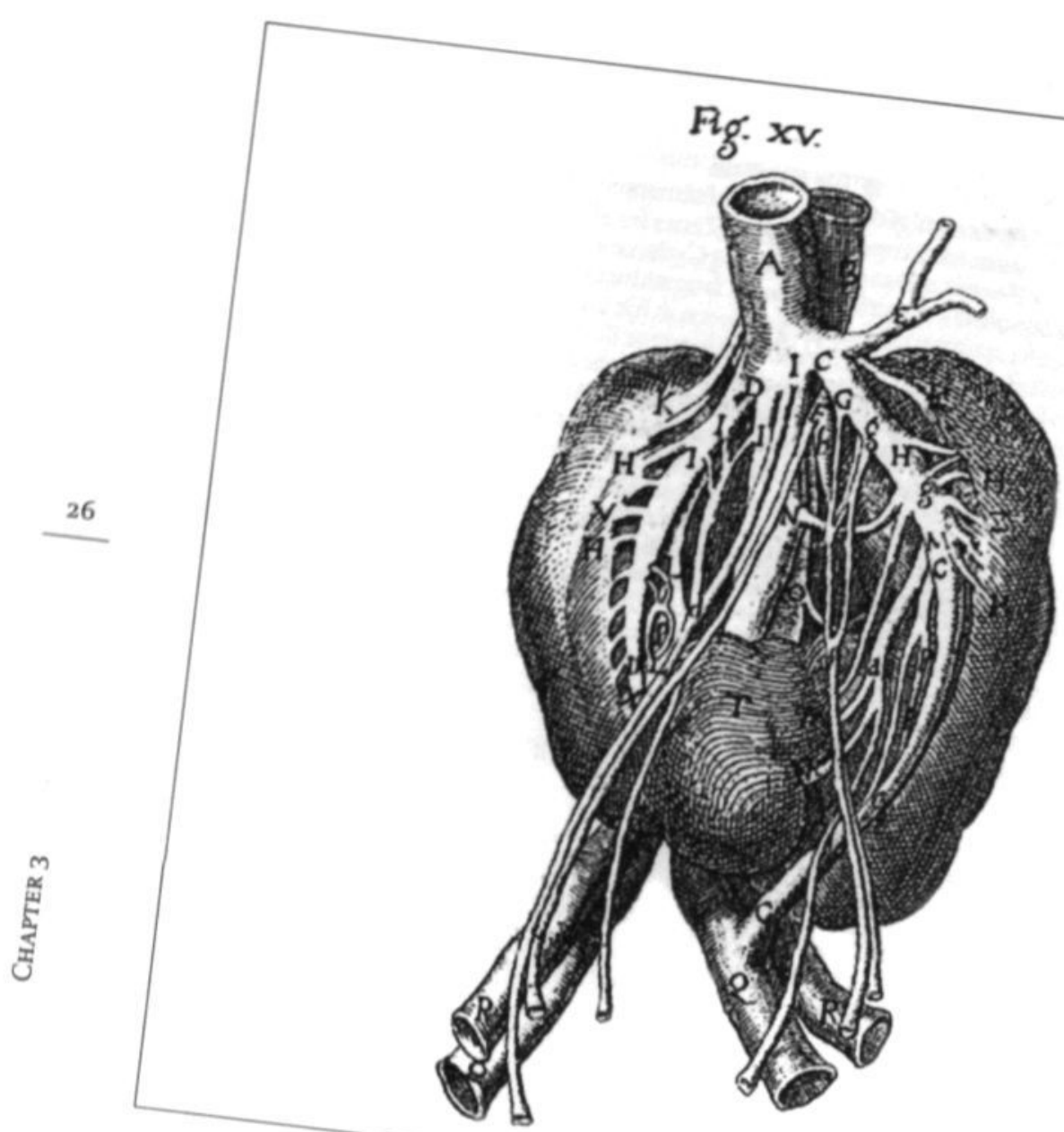

FIGURE 3.2:

First know illustratio

tarius by Leonardo Botallo horseshoe kidney, printed in

anatomica de structura et in the year 1564. (Source: in the catarrho comenthe University Library of Ams renum. Amsterdam: Frisius A. Exercitatio insterdam, the Netherlands. 
Leonardo Botallo, born in Piemonte, physician of Charles IX, king of France (1550-1574), made a description of a "monstrous" kidney, a horseshoe kidney'4. This description was more extensive and accurate than the previous description, and contained the first illustration of a horseshoe kidney (figure 3.2).

"Coming to the kidneys we saw however that nature had put such a trick on them that all spectators were astonished not a little and all who are skilled in anatomical dissections, looking at their shape, will be astonished too. Fortunately the corpse had come into my hands. Otherwise it would have been thrown away and the image of the kidneys, so much monstrous and not seen in past times, would not have been uncovered"." "Four kidneys indeed are united in one mass, yet, as shows the figure, divided among themselves by boundaries and blood vessels. From the emulgents ramified even more vessels than noted, but because these were small, I wanted to give only the greater ones". "It will be appropriate to say also that this man in our opinion was lustful because of the abundance of his seminal blood vessels. Moreover, had he lived longer (what nature perhaps had conceded him while in the other parts she had made him of an excellent corporal constitution, but justice, when he had became a grim murderer, took him away from community with a rope), he would have had oedema. tous swellings of his left leg while the emulgent vein passing over the kidney had been grafted directly into the femoralis [common iliac]. For the kidney, as long as he was strong and forceful (for his face showed that he had not lived more than forty years), sucked up much serous fluid."

The next horseshoe kidney that was reported in the literature was described by Leonard Doldius during a postmortem examination in Nürnberg in the year 1602. His findings were published by Bauhin'. Other descriptions of horseshoe kidneys were given by Barthélemy Cabrol in $1604^{\circ}$. Thomas Bartholin in $1654^{\circ}$, who added a detailed illustration (figure 3.3), Edward Tyson in $1678^{10}$, Stalpart van der Wiel in $1682^{\prime \prime}$ and Giovanni Battista Morgagni in $1761^{12}$, who gave an accurate survey and mentioned cases which had already been published. 


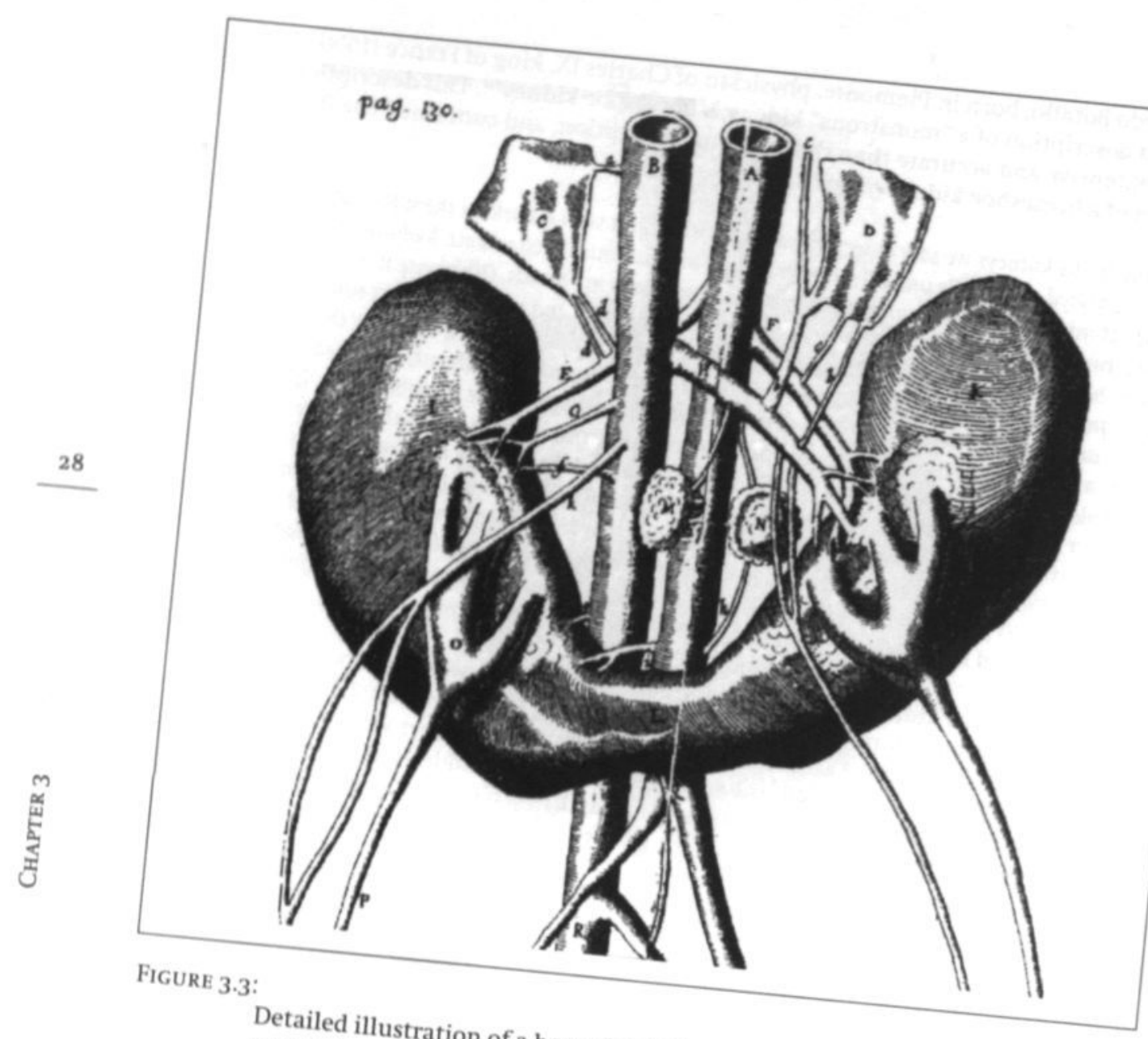

Figure 3.3:

anatomicorum rariorum of horseshoe kidney, printed in the Historiarum Amre: Blasius G. Exercitatio anatomica de structholin in the year 1654 . the Netherlands. 


\section{THE SECOND ERA}

This era dates from the beginning of renal surgery in the second half of the 19th century. Although the horseshoe kidney was no longer seen as a curiosity, not much was known about its physiology and pathology'. Horseshoe kidneys were discovered during an exploratory laparotomy for an undetermined abdominal tumour. Due to the lack of proper diagnosis during this period, some surgeons did not recognise these "tumours" as horseshoe kidneys and erroneously removed them. This obviously led to anuria and death ${ }^{1}$. The technical possibilities were very limited in this period, so when a horseshoe kidney was discovered and recognised, a surgical attempt to relieve symptoms attributed to the horseshoe kidney was often not considered feasible.

\section{THE THIRD ERA}

Diagnosis of a horseshoe kidney by careful abdominal palpation was first described by Israel in $1908^{\circ}$. Rovsing described a syndrome, characterised by nausea, vomiting and abdominal pain accentuated by hyperextension, that could lead to the diagnosis of a horseshoe kidney ${ }^{14}$. With the introduction of the roentgen rays and the intravenous pyelography, the diagnostic possibilities to recognise the horseshoe kidney improved. Using an intravenous pyelogram, Gutierrez introduced the horseshoe kidney pyelographic triangle'. This triangle is made by drawing a line from the most medial part of each pyelum to a reference point on the midline at the height of the iliac crests. The angle between the two lines is significantly smaller in people with a horseshoe kidneys than in people with two kidneys, because the pyela of a horseshoe kidney lie close together. Later horseshoe kidneys could be more easily diagnosed using ultrasound or computed tomography ${ }^{1517}$, or even in the fetus during pregnancy ${ }^{12}$. 9 . This did not only lead to the recognition of symptoms that were caused by horseshoe kidneys, but also to the discovery of a variation of other congenital malformations that might accompany horseshoe kidneys ${ }^{\mathrm{mPL}}$.

Now that symptoms caused by horseshoe kidneys were well recognised and diagnosed a number of different operations were performed to relieve the patients of their symptoms. The main objective in operations upon horseshoe kidneys has been to treat the ureteropelvic junction obstruction that causes the hydronephrosis, calculi and recurrent infections. Initially this was done by division of the renal isthmus with or without nephropexy, or heminephrectomy of the diseased side ${ }^{23 x}$. In 1909 Martinow was the first to divide the renal isthmus in order to separate the fused kidney. Rosving ${ }^{14}$ made a detailed description of the technique in 1910, followed by a modification by Papin in $1922^{2 s}$. Operations for stone removal, either pyelolithotomy or nephrolithotomy as well as tumor excision were also performed ${ }^{232}$. Division of the renal isthmus was gradually abandoned, because it seemed to have little benefit and was often complicated by haemorrhage and urinary fistula formation ${ }^{12}$. The operative treatment of choice for ureteropelvic junction obstruction became the ureteropyeloplasty, or more recently endopyelotomy or ureterocalycostomy ${ }^{10.1234}$. Finally, when laparoscopic surgery was developed, this method could be used in those cases in which heminephrectomy was still indicated ${ }^{15 *}$.

Surgery of the horseshoe kidney is not the only technical challenge. Other abdominal operations can also be complicated by the presence of a horseshoe kidney. The best example is the combination of a horseshoe kidney with an aneurysm of the abdominal aorta. This combination was first described by Julian in $1956^{\prime \prime}$. In 1957 Phelan" was the first to exclude an aortic aneurysm in the presence of a horseshoe kidney. Since then a number of operations have been proposed: Transperitoneal approach with or without division of the renal isthmus, retroperitoneal approach and the placement of a stent graft ${ }^{*}$. 
In 1901 Alexis Carrel paved the way for the first kidney transplantation by developing a technique for vascular anastomosis" ${ }^{* 1}$. After initial experimental transplantations on animals, the first human cadaveric kidney transplantation was performed by Voronoy (18961961 ) in $1933^{2}$. Unfortunately this first renal transplantation failed. The first successful kidney transplantation was performed in Boston by Murray, Merrill and Harrison in $1954^{\circ}$. The identical twin brother of the recipient was willing to donate a kidney. Due to the organ shortage, horseshoe kidneys were also considered for transplantation. The first horseshoe kidney was transplanted by Politano in the USA in 1963 . He removed half a horseshoe kidney and transplanted it into the monozygotic twin of the deceased. The kidney functioned well, although the recipient died eight months posttransplantation of hepatitis. Unfortunately Politano failed to publish his findingst. Credit for that goes to Nelson who published the first case of a split horseshoe kidney transplantation in $1975^{44}$. In these first cases the renal isthmus was divided, following the example of Papin, and a split horseshoe kidney was transplanted. The first en bloc transplantation was performed by Menezes de Goes in São Paulo, Brazil in 1981"s. The horseshoe kidney of a 29 year-old victim of a traffic accident was successfully transplanted into a 50-year-old recipient. In 1996, Lucan in Cluj, Romania was the first to perform a living donation, using a horseshoe kidney". The donor of the split horseshoe kidney was the elder brother of the recipient. The horseshoe kidney was split in situ, leaving one half to the donor. The three renal arteries of the donated left part were anastomosed to a synthetic patch on the backtable, prior to transplantation. Over four years posttransplantation the graft is still functioning well. In 1998, Aikawa, in Japan was the second to perform this type of horseshoe kidney transplantation, in which the father donated half of a horseshoe kidney to his son". Although the recipient suffered urinary fistula formation, requiring multiple reoperations, the graft is still functioning today. Although some transplant surgeons were reluctant to use horseshoe kidneys for transplantation, Stroosma et al. ${ }^{47}$ showed that the posttransplant results of horseshoe kidney transplantation are equal to those with a normal anatomy.

\section{Conclusion}

The horseshoe kidney, a congenital malformation that develops in the fourth to sixth week of gestation, gradually took it's place in medicine. In the Middle Ages it was seen as a curiosity or a monstrous anomaly. However, as the medical sciences gradually developed the anomaly was not only recognised as a congenital malformation, but symptoms and other lesions that might accompany the horseshoe kidney were also discovered. Methods to diagnose these symptoms and accompanying lesions gradually improved, as did the various operations to treat them. This is what we might call the expected course of the development of medicine. Possibly more unexpected, is the fact that horseshoe kidneys might once be used for transplantation. When Botallo described the monstrous shape of the horseshoe kidney, he would probably never have foreseen that this congenital malformation that was initially thought to be a disease and later known to cause disease. would eventually be used to safe human life as a renal allograft. 


\section{FOOTNOTES}

A.

Ego ipse etiam vidi anno 1521 in studio nostro Bononiensi in anatomizato publice arteriam unam ex emulgentibus facere unum porum in parte dextra extra renem qui in notabili distantia infra renem ingrediebatur porum uritidem a praedicto rene ortum; et ambo per unum canalem tendebant ad vesicam. Haec tamen etiam arteria emulgens ingrediebatur renem in loco solito; et in isto individuo renes erant continui ac si esset unus ren; et habebat duas venas et duas arterias emulgentes; et duos poros uritides cum uno solo panniculo involvente qui occupabat loca solita renum: et etiam medium dorsi; quod est in loco inter splenem et hepar parum infra ea.

B.

Renal arteries and veins were called emulgents or milkers, milking or draining blood to the kidneys. The teachings of Galenus (130-ca. $200 \mathrm{AD})^{\mathrm{s}}$ still dominated the western medicine until William Harvey (1578-1657) discovered the continuous blood circulation. In the model of Galenus blood was formed in the liver from the food ingested. The blood was then transported from the liver through the vena cava inferior to all parts of the body, including right cardiac ventricle and lungs, and absorbed as nutrition. The veins, like the arteries, ended in small openings, anastomosis. The arteries near the heart drained in the outer air from the lungs through the left cardiac ventricle, those further from the heart form the anastomosis in the skin. Via side to side communications blood went from veins to arteries and air (pneuma) from arteries to veins. Both veins and arteries were distributing blood to all parts of the body. The kidneys were receiving blood from the "emulgent" veins and arteries.

C.

It is uncertain what Da Carpi meant by the description of the artery that accompanies the ureteric duct to the bladder. It could be an ovarian or testicular artery, that was described.

D.

Botallo was apparently not familiar with the earlier observation on the anomaly.

E.

A venous anomaly is described here. Blood went from the vena cava inferior to the kidney and via the anomalous emulgent vein to the left common iliac vein and the left leg (see footnote B).

F.

The results of this transplantation were mentioned as a personal correspondence in the publication of Nelson in 1975.

G.

Lucan, M. Personal communications, October 2000. 


\section{References}

1. Gutierrez R. The clinical management of the horseshoe kidney. New York: Hoeber PB, 1934.

2. Berenger da Carpi. Isagoge breves perlucide ac uberrime in anatomiam humani corporis. Bologne: per Benedictum Hectoris, 1522.

3. Botallo L. De catarrho commentarius. Parisís: apud Bernardum Turrifanum. 1564.

4. Benjamin JA. Schullian DM. Observations on fused kidneys with horseshoe configuration: The contribution of Leonardo Botallo (1564). J Hist Med 1950: 5: 315-26.

5. Galenus C. De placitis Hippocratis et Platonis VI 3, VIII 1. De naturalibus facultatibus III 14.

6. Harvey W. Exercitatio anatomica de motu cordis et sanguinis in animalibus. Frankfurt am Main: 1628.

7. Bauhinus C. In: Blasius G. ed. Exercitatio anatomica de structura et usu renum. Amsterdam: Frisius A, 1665: 102-8.

8. Cabrol B. Alphabeta Anatomicorum. Genève: 1604.

9. Bartholin T. Historiarum anatomicarum rariarum centuria. Hafniae: 1654.

10. Tyson E. Philos. Trans. Roy. Soc. London 1678: 12: $1038-9$.

11. Stalpart van der Wiel C. Hondert seltsame aanmerkingen, so in de genees- als heel- en snijkonst. Amsterdam: 1682

12. Morgagni GB. De sedibus et causis morborum per anatomen indagatis libri quinque. Venice: 1761 . Translated from the Latin by Alexander B. In: The seats and causes of diseases investigated by anatomy in five books. Bool III Vol. II Letter XIVIII Article 16. London: Paternoster Row, 1769: 71420.

13. Israel J. Diagnosen und Operationen, bei verschmolzenen Nieren. Folia urolog 1908: 1:617-41.

14 Rovsing T. Beitrag zur Symptomatologie, Diagnose und Behandlung der Hufeisenniere. Ztschr fUrol 1911: 5 : $586-601$.

15. Strauss S. Sushnitsky T, Peer A. Manor H. Libson E, Lebensart PD. Sonographic features of horseshoe kidney: . mviewe of 34 matienty I Ultrasound Med 2000: 19:27-31.

16. Banerjee B, Brett I. Ultrasound diagnosis of horseshoe kidney. Br J Radiol 1991: 64: 898-900.

17. Nguyen KT. Downey M. Gutelius J. An unusual case of horseshoe kidney: CT appearance. Can Assoc Radiol J 1989: 40:320-1.

18. King KL. Kofinas AD, Simon NV, Clay D. Antenatal ultrasound diagnosis of fetal horseshoe kidney. J Ultrasound Med 1991: 10: 643-4.

19. Kovo-Hasharoni M. Mashiach R. Levy S, Meizner I. Prenatal sonographic diagnosis of horseshoe kidney. J Clin Ultrasound 1997: 25:405-7.

20. Zondek L.H. Zondek T. Horseshoe kidney and associated congenital malformations. Urol Int 1964: 18:347.56.

21. Boatman DL. Kolln CP. Flocks RH. Congenital anomalies associated with horseshoe kidney. J Urol 1972: 107: 205-7.

22. Grainger R. Lane V. Murphy DM. Horseshoe kidney - a review of the presentation, associated congenital anomalies and complications in 73 patients. Irish Med J 1983: 76:315-7.

23. Lowsley OS. Surgery of the horseshoe kidney. J Urol 1952: 67:565-78.

24. Dahlen C. Schlumberger FC. Surgery of the diseased horseshoe kidney. Am J Surg 1957:93:405-12.

25. Dajani AM. Horseshoe kidney: a review of twenty-nine cases. Br J Urol 1966: 37: 388-402.

26. Kilpatrick FR. Horseshoe kidneys. Proc R Soc Med 1967; 60: 433-8.

27. Martinow AV. Intervention sur le rein en fer à cheval. Zentralbl fChir 1910: $37: 3146$

28. Papin E. Rein en fer à cheval. Section de l'isthme. Ass Franc d'Urol. XXII Congrès. Paris: 1922: p. 557.

29. Nation EF. Horseshoe kidney, a study of thirty-two autopsy and nine surgical cases. J Urol 1945: 53: 762-8.

30. Culp OS, Winterringer JR. Surgical treatment of horseshoe kidney: comparison of results after various types of operations. J Urol 1955: $73: 747.56$

31. Lathem JE. Smith KH. Wilms tumor in a horseshoe kidney: A surviving case. J Urol 1962: 88: $25-8$.

32. Pitts jr WR. Muecke EC. Horseshoe kidneys: a 40-year experience. J Urol 1975; 113: 743-6.

33. Dewan PA. Clark S. Condron S. Henning P. Ureterocalycostomy in the management of pelvi-ureteric junction obstruction in the horseshoe kidney. Br J Urol 1999: 84:366-8. 
34. Nakamura K, Baba S. Tazaki H. Endopyelotomy in horseshoe kidneys. J Endourol 1994: 8: $203-6$.

35. Riedl CR. Huebner WA. Schramek P. Pflueger H. Laparoscopic hemi-nephrectomy in a horseshoe kidney. Br J Urol 1995: 76: 140-1.

36. Donovan JF, Cooper CS, Lund GO, Winfield HN. Laparoscopic nephrectomy of a horseshoe kidney. J Endourol 1997: 11: $181-4$.

37. Hayakawa K. Baba S. Aoyagi T. Ohashi M. Ishikawa H. Hata M. Laparoscopic heminephrectomy of a horseshoe kidney using microwave coagulator. J Urol 1999; 161: 1559.

38. Julian OC. Diagnosis in arterial disease. Surg Clin North Am 1956: 36: 177-91.

39. Phelan JT. Bernatz PE, DeWeerd JH. Abdominal aortic aneurysm associated with a horseshoe kidney: Report of a case. Proc Staff Meet Mayo Clin 1957: 32: 77-81.

40. Stroosma OB, Kootstra G. Schurink GWH. Management of aortic aneurysm in the presence of a horseshoe kidney. Br J Surg 2001: 88: 500-9.

41. Kuss R. Bourget P. Une histoire illustrée de la greffe d'organes. Rueil-Malmaison: Sandoz, 1992: $24-46$.

42. Hamilton DNH. Ried WA. Yu.Yu.Voronoy and the first human kidney allograft. SG\&O, 1984 vol.159: 289.94.

43. Murray JE, Merrill JP. Harrison JH. Renal homotransplantation in identical twins. Surg Forum 1955: 6: 432-3.

44. Nelson RP. Palmer JM. Use of horseshoe kidney in renal transplantation: technical aspects. Urology 1975; 6:357-9.

45. Menezes de Goes G. De Campos Freire G. Borrelli M. Pompeo AC, Wroclawski ER. Transplantation of a horseshoe kidney. J Urol 1981: 126: 537-8.

46. Aikawa M. Hashiba T. Dobashi Y. Inoue S, Kuzuhara K. Otsubo O. A case report of use of horseshoe kidney as renal transplant from live donor [Japanese]. Nippon Hinyokika Gakkai Zasshi 1998: 89: 62-5.

47. Stroosma OB, Smits JMA. Schurink GWH, de Boer J. Persijn GG, Kootstra G. Horseshoe kidney transplantation within the Eurotransplant region: a case control study. Transplantation. In Press. 
点 
Chapter 4

\section{Horseshoe kidney transplantation: an overview}

O.B. Stroosma, M.R.M. Scheltinga,

B.M. Stubenitsky, G. Kootstra

Published in:

Clinical Transplantation 2000; 14: 515-9. 


\section{INTRODUCTION}

The pool of patients with end stage renal failure awaiting kidney transplantation has expanded over the past years, whereas the number of cadaveric organ donors has diminished. Due to this discrepancy, kidneys with atypical anatomy should be considered as an additional source for transplantation. The most frequently observed anatomical variation of the kidney is the horseshoe type, with an incidence of one in 600 to $800^{1}$. Horseshoe kidneys are more common in males than in females (2:1), and may occur familial $^{2.3}$. In 1522 Da Carpi was the first to document a case of a horseshoe kidney , but $^{4}$ it was not until the beginning of the twentieth century that the frequency of occurrence and clinical relevance became known'. The goal of this review is to assess the results of horseshoe kidney transplantations described in literature. Strategies on the evaluation and technical aspects of horseshoe kidney transplantation are proposed. All data were collected by a Medline search using the keywords horseshoe kidney and transplantation and by crosschecking reference lists.

\section{CAN HORSESHOE KIDNEYS BE USED FOR TRANSPLANTATION?}

Transplantation of a horseshoe kidney can be performed en bloc into one individual (figure 4.1). or it can be split and transplanted into two recipients (figure 4.2), depending on the number of vessels and the anatomy of the urinary collecting system ${ }^{6.7}$. The first split transplantation of a horseshoe kidney was performed by Politano in 1963 . He successfully implanted the right half of a horseshoe kidney into the monozygotic twin of the donor. but failed to publish his findings". Nelson is credited for publishing the first case of a horseshoe kidney transplantation in $1975^{\circ}$. 


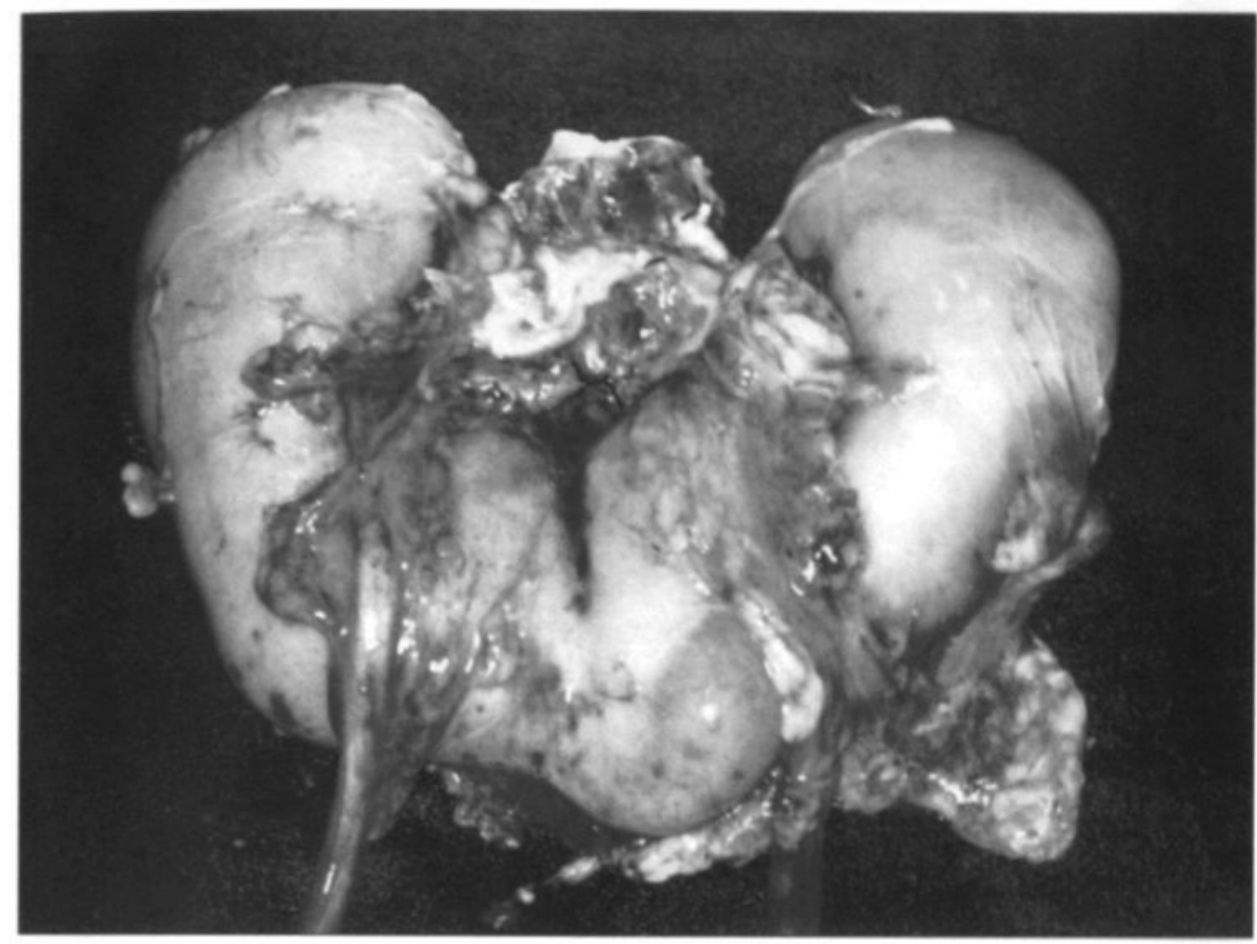

FIGURE 4.1:

Horseshoe kidney after en bloc explantation.

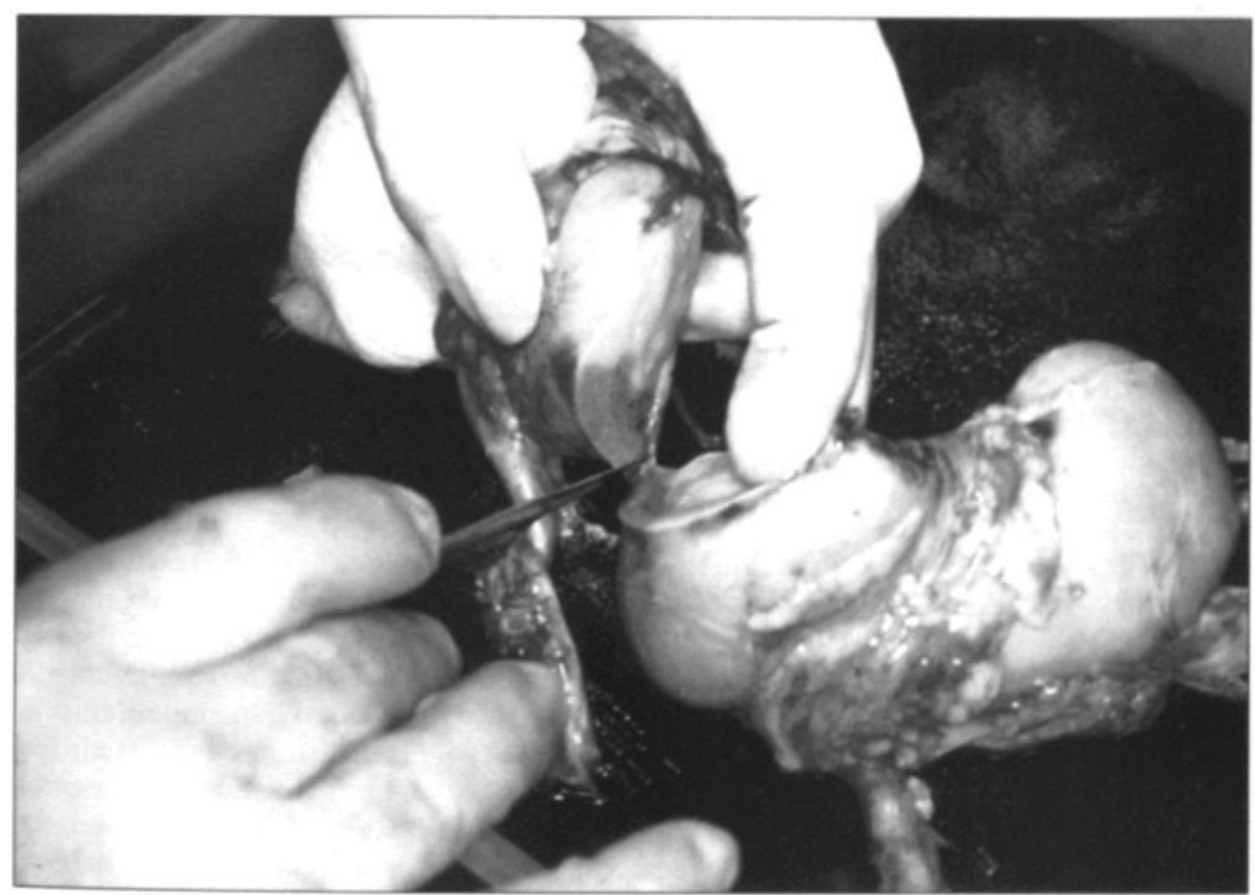

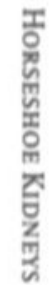

FIGURE 4.2:

Division of the parenchymatous renal isthmus of a horseshoe kidney. 


\begin{tabular}{|c|c|c|c|c|c|}
\hline Year & Author & Country & Cases & En bloc/Split & Remarks \\
\hline 1975 & NeISON & USA & 1 & SPLIT & \\
\hline 1978 & BRANDINA & BrAZIL & 1 & SPLIT & \\
\hline 1979 & MAJESKI & USA & 1 & SPLIT & \\
\hline 1981 & MENEZES DE GOES & BrazIL & 1 & SpLIT & \\
\hline 1983 & BRANDINA & BrazIL. & 1 & SPLIT & \\
\hline 1984 & BARRY & USA & 1 & SPLIT & \\
\hline 1986 & VROMEN & THE NETHERLANDS & 1 & SPLIT & \\
\hline 1987 & Kı.̋̃N & GERMANY & 1 & EN BLOC & \\
\hline 1989 & GoRREA & Spain & 2 & SPLIT $(2 x)$ & \\
\hline 1990 & BRENNER & USA & 1 & EN BLOC & \\
\hline 1992 & VIGNES & France & 1 & SPLIT & \\
\hline 1993 & RATNER & USA & 1 & EN BLOC & \\
\hline 1993 & WHITE & USA & 1 & SPLIT & KIDNEY-PANCREAS TX \\
\hline 1993 & Nemec & CZECh RepubLic & 1 & SpLIT & \\
\hline 1993 & HAYES & USA & 1 & SPLIT & ONE HALF DISCARDED \\
\hline 1994 & LOWELL & USA & 1 & EN BLOC & \\
\hline 1996 & MURPHY & USA & 1 & SpLIT & AUTOTRANSPLANTATION \\
\hline 1996 & PAYEN & France & 1 & SpLIT & \\
\hline 1996 & Perumalla & CANADA & 1 & SPLIT & \\
\hline 1996 & BоттА & ITALY & 2 & Sptrt $(2 x)$ & \\
\hline 1997 & NAVRÁtIL. & CZech Republic & 1 & EN BLoc & \\
\hline 1997 & Tномson & AUSTRALIA & 2 & EN BLOC (2X) & \\
\hline 1998 & AikaWa & JAPAN & 1 & SPLIT & LIVING RELATED DONATION \\
\hline 1998 & MERKEL. & USA & 1 & EN BLOC & \\
\hline 1998 & MoURANI & LIBANON & 1 & EN BLoC & \\
\hline 1998 & SHEN & USA & 1 & SpLIT & \\
\hline 1999 & Stroosma & THE NETHERLANDS & 2 & SPLIT (2x) & \\
\hline
\end{tabular}

TABLE 4.1:

Published cases of horseshoe kidney transplantation. (Tx: transplantation). 
Our literature review reveals that since then 31 horseshoe kidneys have been transplanted into 48 recipients (table 4.1), ten of which were en bloc transplants ${ }^{2 * 16}$. The other 21 were divided and transplanted into 38 recipients ${ }^{2} \times 4$. The mean donor age was 29 years (range $3-65$ ). $76 \%$ of the donors were male, $24 \%$ were female. When studying the vascular anatomy of these cases, it was observed that the mean number of arteries and veins was 5 (range 2-9) and 3 (range $2-5)$ respectively. There was no difference in the number of arteries and veins between the horseshoe kidneys transplanted en bloc or split. The cold ischaemic time (CTT) ranged from 2.5 to 61 hours, with a mean of 30 hours. Of the recipients $53 \%$ was male and $47 \%$ was female. The mean age of the recipients was 42 years (range 7-69). Transplantation results are shown in table 4.2. Eightyseven percent of the grafts were successfully transplanted with a mean serum creatinin of $160 \mu \mathrm{mol} / 1$ after a mean follow-up of 22 months (range 1-144). Primary non function was observed in a total of 6 grafts (13\%), leading to an early transplantectomy. In three cases $(6 \%)$ this was caused by thrombosis of one or more renal arteries, twice in a split and once in an en bloc transplanted horseshoe kidney.

Acute rejection was the cause of primary non function in two cases. The sixth transplantectomy was performed for haemorrhage of a ruptured allograft. Urinary fistula formation after injury to the urinary collecting system following symphysiotomy was seen in one recipient, necessitating multiple reoperations. The transplantation results of two $\operatorname{cases}^{12 .}$ could not be determined. No significant differences could be found between the posttransplant results of en bloc transplantation of horseshoe kidneys versus transplantation of horseshoe kidneys after division of the isthmus. Long-term results (one to five year graft and patient survival and serum creatinine values) could not be gathered from the literature.

\begin{tabular}{|llll|}
\hline & $\begin{array}{l}\text { Horseshoe kidney } \\
\text { en bloc }(\mathrm{N}=10)\end{array}$ & $\begin{array}{l}\text { Horseshoe kidney } \\
\text { split }(\mathrm{N}=36)\end{array}$ & $\begin{array}{l}\text { Horseshoe kidney } \\
\text { total }(\mathrm{N}=46)\end{array}$ \\
\hline Immediate function & $4(40 \%)$ & $15(42 \%)$ & $19(41 \%)$ \\
\hline Delayed function & $5(50 \%)$ & $16(44 \%)$ & $21(46 \%)$ \\
\hline Primary non function & $1(10 \%)$ & $5(14 \%)$ & $6(13 \%)$ \\
\hline
\end{tabular}

TABLE 4.2:

Results of the transplantation of horseshoe kidneys. (Immediate function: direct funtion of the graft after transplantation without the further need of dialysis: Delayed function: the recipient needs dialysis (not according to protocol) after transplantation before the graft starts to function: Primary non function: the graft never functiones).

\section{Discussion}

Our review suggests that posttransplant results of horseshoe kidneys are generally acceptable. In addition, results of en bloc transplantation were similar to the results after division of the horseshoe kidney, although the numbers are small (table 4.2). Although the comparison is not completely reliable, these results seem to be slightly less favorable compared to the posttransplant results of heartbeating kidney transplantations within the Eurotransplant region". These differences could be explained by the relatively longer cold ischaemic time that was observed in the group of horseshoe kidneys.

Moreover, some of the horseshoe kidneys were transplanted before cyclosporine was used as an immunosuppresive drug. Finally, transplanting these type of kidneys may be technically demanding. which may have contributed to the higher percentage of primary nonfunction. mainly due to thrombosis of the vessels, which was observed in $6 \%$ of the transplantations. Therefore, certain conditions should be met when initiating a horseshoe kidney transplantation"? 
Firstly, the donor should not have a history of urinary tract disease. Secondly, during explantation the ureters are to be severed as close to the bladder as possible since they are usually shorter than normal. The kidney should be explanted en bloc, leaving all the renal arteries and the aorta intact. Careful inspection of the vasculature and visualization of the urinary collecting system should be performed on a backtable. Although it is rare for the collecting systems of fused kidneys to be contiguous, the urinary collecting systems can override into the contralateral part of the kidney, a situation observed in horseshoe kidneys with a lateral fusion ${ }^{5.3 . x}$. An overriding collecting system can be excluded by retrograde injection of a radiopaque contrast medium via both ureters and subsequent radiological evaluation. Division is only allowed if the urinary collecting systems remain undamaged. When dividing a horseshoe kidney half the aorta should be preserved as a patch, containing the orfices of all renal arteries. If divided, transplantation should preferentially take place into the ipsilateral iliac fossa since the veins are usually shorter than normal. Adequate haemostasis should be obtained after division. This is done by making a conelike excision after which the wound edges can be approximated following closure of the renal capsula. When division is contra-indicated, the horseshoe kidney should be transplanted en bloc. Technically this procedure is not different from the transplantation of paediatric en bloc kidneys into adult recipients ${ }^{37}$. The aorta and the vena cava inferior are oversewn either distally or proximally, whereas the opposite ends are anastomosed to the iliac vessels. The ureters can be anastomosed to the bladder after being conjoined, but they may also be separately implanted.

A number of cases described in literature deserve to be mentioned separately. The first is a case of autotransplantation of a horseshoe kidney after severe injury following a traffic accident ${ }^{17}$. A horseshoe kidney which was fractured into four parts was reconstructed on a backtable. The part, having an intact urinary collecting system, was successfully autotransplanted into the patient. This case illustrates the vulnerability of a horseshoe kidney due to its position relative to the promontorium.

A second case worth mentioning is a successful pancreas transplantation combined with a split horseshoe kidney ${ }^{12}$. Both kidney and pancreas were functioning well after a follow-up of two years.

Finally a case was published in which an in situ split horseshoe kidney was used as a graft in a living related donation ${ }^{11}$. Although a urinary fistula formed in the recipient, necessitating multiple reoperations, kidney function was good. The use of horseshoe kidneys in living donation might be an important future development in expanding the donor pool. As some cases of laparoscopic heminephrectomy of a horseshoe kidney have already been published $^{1 *+0}$, it might even be possible to perform laparoscopic live donor heminephrectomies of horseshoe kidneys.

In conclusion, this review demonstrates that the transplantation of horseshoe kidneys. either en bloc or split can be done with generally good results, provided that certain conditions are met. Taking in account the growing shortage of cadaver donors, horseshoe kidneys should be used for transplantation. 


\section{References}

1. Bauer SB. Anomalies of the kidney and ureteropelvic junction. In: Walsh PC, Retik AB, Vaughan ED Jr, Wein AJ. eds. Campbell's urology. Philadelphia: WB Saunders, 1998: 1708-57.

2. David RS. Horseshoe kidney: a report of one family. Br Med J 1974: $4: 571-2$.

3. Boatman DL, Hawtrey CE. Familial horseshoe kidney.J lowa Med Soc 1973: 63: 399-401.

4. Berenger da Carpi. Isagoge breves perlucide ac uberrime in anatomiam humani corporis. Bologne: per Benedictum Hectoris, 1522.

5. Farman F. Fusion anomalies of the kidney. In: Alken CE, Dix VW, Goodwin WE, Weyrauch HM, Wildbolz E eds. Encyclopedia of urology, Vol.VII/1. New York: Springer-Verlag, 1968: 66-72.

6. Vromen MAM. Kootstra G. The use of horseshoe kidneys for transplantation. Transpl Proc 1988: $20: 765-6$.

7. Ratner LE, Zibari G. Strategies for the successful transplantation of the horseshoe kidney. J Urol 1993: 150:958-60.

8. Nelson RP. Palmer JM. Use of horseshoe kidney in renal transplantation: technical aspects. Urology 1975:6:357-9.

9. Thomson BN, Francis DM, Millar RJ. Transplantation of adult and paediatric horseshoe kidneys. Aust N Z J Surg 1997: 67: 279-82.

10. Brenner DW, Schlossberg SM. Hurwitz RL. Transplantation of horseshoe kidney into single recipient. Urology 1990: 35: 530-2.

11. Menezes de Goes G. De Campos Freire G, Borrelli M. Pompeo AC. Wroclawski ER. Transplantation of a horseshoe kidney. J Urol 1981: 126:537-8.

12. Lowell JA. Taylor RJ, Cattral M. Stevenson Bynon J. Brennan DC. Stratta RJ. En bloc transplantation of a horseshoe kidney from a high risk multi-organ donor: case report and review of the literature. J Urol 1994: 152:468-70.

13. Klan R. Hirner A. Fiedler U, Offermann G. Transplantation of a horseshoe kidney en bloc: report of a case. JUrol 1988: 139:571-2.

14. Navrátil P. Veselsky Z, Hafuda A. Transplantace podkovovité ledviny. Rozhl Chir 1997: 76: 443-5.

15. Merkel FK, Miller JL. Transplantation of a pediatric horseshoe kidney into an adult recipient. Pediatric Transplantation 1998: 2: 70 .

16. Mourani C. Moukarzel. Monobloc pediatric horseshoe kidney transplantation in a pediatric recipient. Pediatric Transplantation 1998: 2: 69.

17. Murphy JT. Borman KR. Dawidson I. Renal autotransplantation after horseshoe kidney injury: a case report and literature review. J Trauma 1996: 40: 840 .

18. Shen GK. Salvatierra jr. O. Dafoe DC, Alfrey EJ. Use of split horseshoe kidney for transplantation. Surgery 1998: 123:475-7.

19. Botta GC, Capocasale E, Mazzoni MP. Transplantation of horseshoe kidneys: a report of four cases. Br J Urol 1996: $78: 181-2$.

20. Perumalla C, Lawen JG, MacDonald AS. Transplantation of a horseshoe kidney into two recipients after separation. Br J Urol 1996: 78: $145-6$.

21. Payen E. Bretheau D. Lechevallier E, Berland Y. Olmer M. Coulange C. Transplantation of a horseshoe kidney into 2 recipients. Urol Int 1996: 56: $107-9$.

22. Barry JM, Fincher RD. Transplantation of a horseshoe kidney into 2 recipients. J Urol 1984: 131: 1162-3.

23. Majeski JA, Alexander JW. First R, Munda R. Fidler JP. Transplantation of a horseshoe kidney. JAMA 1979: $242: 1066$.

24. Brandina L. Mocelin AJ. Fraga AM. Lacerda G. Transplantation of a horseshoe kidney. Br J Urol 1978: $50: 284$.

25. Brandina L. Fraga AM, Bergonse MR, et al. Kidney transplantation: the use of abnormal kidneys. Nephron 1983: 35: 78-81.

26. Vromen MAM, van der Vliet JA. Ruers TJM. Muller GH. Kootstra G. Use of horseshoe kidneys for transplantation. The Netherlands Journal of Surgery 1986: 38: $183-6$.

27. Gorrea MA, Dominguez Hinarejos C. Broseta Rico E, Guillen Navarro M. Pallardo L. Jimenez Cruz JF. Rinón en herradura: su utilidad en el trasplante. Arch Esp de Urol 1989:42:353-5.

28. Hayes JM. The transplantation of difficult donor kidneys and recipients: helpful surgical techniques. J Urol 1993: 149: $250-4$. 
29. Vignes B, Cussenot $O$, Braun R, et al. Transplantation d'un rein en fer à cheval a propos d'une observation et revue de la littérature. Prog Urol 1992: 2: $282-6$.

30. Nemec P, Uchytil B, Pospichal V. Transplantace podkovovité ledviny. Rozhl Chir 1993: 72: 390-1.

31. Aikawa M, Hashiba T, Dobashi Y, Inoue S, Kuzuhara K, Otsubo O. A case report of use of horseshoe kidney as renal transplant from live donor Uapanese]. Nippon Hinyokika Gakkai Zasshi 1998: 89: 62-5.

32. White JC, Shaver TR, Kocandrle V. Simultaneous kidney-pancreas transplantation using a horseshoe kidney. Transpl Int 1993: 6: 302-3.

33. Stroosma OB, Scheltinga MRM, van den Akker LHJM, Rizvi SAH, Naqvi SAA, Kootstra G. Successful transplantation of a divided horseshoe kidney following prolonged donor hypotension and long distance transportation. Transplant International 2001: 14: 56-7.

34. Stroosma OB, Kootstra G. Transplanting horseshoe kidneys: the Maastricht experience. Transplantation Proceedings 2000: 32: 1602-3.

35. de Boer J, De Meester J, Smits JMA, et al. Eurotransplant randomized multicenter kidney graft preservation study comparing HTK with UW and Euro-collins. Transplant Int 1999: 12: 447-53.

36. Dajani AM. Horseshoe kidney: a review of twenty-nine cases. Br J Urol 1966: 37: 388-402.

37. Hobart MG, Modlin CS, Kapoor A. Transplantation of pediatric en bloc cadaver kidneys into adult recipients. Transplantation 1998: 66: 1689-94.

38. Hayakawa K, Baba S, Aoyagi T, Ohashi M. Ishikawa H. Hata M. Laparoscopic heminephrectomy of a horseshoe kidney using microwave coagulator. J Urol 1999: 161: 1559.

39. Donovan JF, Cooper CS, Lund GO, Winfield HN. Laparoscopic nephrectomy of a horseshoe kidney. J Endourol 1997: 11: 181-4.

40. Riedl CR. Huebner WA, Schramek P. Pflueger H. Laparoscopic hemi-nephrectomy in a horseshoe kidney. Br J Urol 1995: 76: 140-1. 


\title{
CHAPTER 5
}

\section{CURRENT OPINIONS IN HORSESHOE KIDNEY} TRANSPLANTATION

\author{
O.B. Stroosma, G.W.H. Schurink, G. Kootstra
}

Submitted for publication 


\section{INTRODUCTION}

Because of the increasing shortage of cadaver organ donors, kidneys with an atypical anatomy are also considered for transplantation. The horseshoe kidney is the most common anatomical variation of the kidney, with an incidence of one in 600 to $800^{\prime}$.

Horseshoe kidneys display a great variation in origin, number and size of renal arteries and veins'. This makes it technically more challenging to use them for transplantation. Horseshoe kidneys can be transplanted en bloc or they can be divided and transplanted into two recipients. Due to it's low incidence there are no protocols for the transplantation of horseshoe kidneys. A study of the literature reveals some publications with recommendations on this subject ${ }^{2.3}$. However, these recommendations were often based on a case report. The aim of this study is to investigate the current opinions on the technique and results of horseshoe kidney transplantation among the transplant surgeons throughout Europe.

\section{METHODS}

The names and addresses of all the members of the European Society for Organ Transplantation (ESOT) were obtained through its secretary. The addresses of the members were searched for the departments of general surgery, transplant surgery or urology. These members of the ESOT were send a questionnaire. Eleven questions were asked regarding the experience in the explantation and transplantation of horseshoe kidneys, whether they would transplant a horseshoe kidney when offered, what operative and diagnostic procedures concerning the explantation and transplantation of horseshoe kidneys they would follow and finally their opinion on the results of horseshoe kidney transplantation compared to kidneys with a normal anatomy (figure 5.1). 
Name:

City:

Country:

1. Have you ever procured a horseshoe kidney?

aYes a No

2. If yes, was that horseshoe kidney transplanted?

aYes aNo

3. Have you ever transplanted a horseshoe kidney?

aYes

a No

4. When you were offered a horseshoe kidney, would you transplant it?

ayes a No

5. If not, why?

6. If yes, would you transplant it en bloc or split?

DEn bloc a Split a Depending on

7. On what would your decision depend?

a Number of renal arteries

Number and position of renal arteries

a Parenchymatous or fibrous isthmus

$\square$ Anatomy of urinary collecting system

JOther:

8. How would you explant a horseshoe kidney?

an bloc, inspection on backtable a Split in situ

aOther:

9. How would you diagnose the isthmus and the urinary collecting system of the horseshoe kidney after procurement?

$\square$ No diagnostic test, just inspection $\quad$ Injection of contrast into the ureters

Jother:

10. What are the results of horseshoe kidney transplantation in comparison to "normal" kidneys in your opinion? Please guess.

Jetter than "normal" kidneys JWorse than "normal" kidneys

J Equal to "normal" kidneys

11. Do you have any other comment? 


\section{RESULTS}

A total of 282 questionnaires were send. The response rate was $46.1 \%$. Of the 130 forms that were returned, 18 were incomplete and discarded, leaving 112 forms for analysis. Of these 112 surgeons, $73(65.2 \%)$ had procured a horseshoe kidney. These horseshoe kidneys were transplanted in $32(43.8 \%)$ cases. Sixteen $(21.9 \%)$ horseshoe kidneys had been discarded and $25(34.2 \%)$ surgeons could not remember whether the horseshoe kidney was transplanted or not. Of the 112 participating surgeons, $30(26.8 \%)$ had transplanted a horseshoe kidney, compared to $82(73.2 \%)$ who had not. When they were offered a horseshoe kidney, $102(91.1 \%)$ surgeons would transplant it. Ten $(8.9 \%)$ surgeons would discard the horseshoe kidney. Reasons that were given for discarding a horseshoe kidney had to do with the risk involved in transplanting a graft with a high vascular complexity.

Twentythree $(22.5 \%)$ of the surgeons who would transplant the horseshoe kidney, would transplant it en bloc. Transplantation after division of the renal isthmus would be performed by $19(18.6 \%)$ surgeons. A total of $60(58.8 \%)$ surgeons would let their decision to transplant en bloc or after division depend on the following factors: the number of renal arteries $(n=8 ; 7.8 \%)$, the number and position of the renal arteries $(n=57 ; 55.9 \%)$, a parenchymatous or fibrous isthmus $(n=38 ; 37.3 \%)$ and the anatomy of the urinary collecting system $(n=53 ; 52.0 \%)$. Other factors mentioned were: the donor and recipient age $(n=4: 3.9 \%)$, the anatomy of the veins $(n=2: 2.0 \%)$, the parenchymal mass of the renal isthmus $(n=2: 2.0 \%)$ and the compatibility and urgency $(n=1 ; 1.0 \%)$.

The horseshoe kidney would be explanted en bloc and, when applicable divided on the backtable by $93(91.2 \%)$ surgeons. Seven $(6.9 \%)$ surgeons would split the horseshoe kidney in situ before explanting it. Two $(2.0 \%)$ surgeons proposed to let the decision depend on the donor condition. If the donor was haemodynamically stable the division of the renal isthmus should be performed in situ, to limit ischaemic time. The majority of the surgeons $(n=61 ; 59.8 \%)$ did not need a diagnostic test to be informed on the anatomy of the isthmus and the urinary collecting system after procurement. The other option given on the questionnaire (injection of contrast into the ureters, followed by an X-ray) was chosen by $35(34.3 \%)$ surgeons. Four $(3.9 \%)$ surgeons proposed to use methylene blue to inform themselves on the anatomy of the urinary collecting system and two surgeons $(2.0 \%)$ proposed to cannulate the urinary collecting system with a probe to get an idea of the anatomy.

Six of the total of 112 surgeons $(5.4 \%)$ thought that the posttransplant function of horseshoe kidneys were better than that of kidneys with a normal anatomy. They all added to the form that this would only be true for en bloc transplanted horseshoe kidneys. Most surgeons $(n=80: 71.4 \%)$ thought that the results of horseshoe kidney transplantation would be equal to that of kidneys with a normal anatomy and $26(23.2 \%)$ surgeons thougth the results to be worse. No differences could be found in the answers of the surgeons who had actually transplanted a horseshoe kidney and those who had not.

\section{Discussion}

A total of 31 cases of horseshoe kidney transplantation have been described in literature'. Because of the technical challenge involved in transplanting this type of kidney and the low frequency, some surgeons seem to be reluctant to use horseshoe kidneys for transplantation. In this study the opinions of 112 surgeons in the field of kidney transplantation were analysed. The reluctance to use horseshoe kidneys for transplantation is shown by the fact that $65.2 \%$ of the surgeons had explanted a horseshoe kidney, of which at least $21.9 \%$ was discarded. However. only $8.9 \%$ of the surgeons would refuse a horseshoe kidney when offered. 
Only a few surgeons would transplant the horseshoe kidney en bloc or split on forehand $(22.5 \%$ and $\mathbf{1 8 . 6 \%}$ respectively). Most $(\mathbf{5 8 . 8} \%)$ would let their decision depend on one or more parameters. The decision of most surgeons in both groups depended on the number and position of the renal arteries. Bearing in mind the often complex vascular anatomy it seems to be advisable to transplant a horseshoe kidney en bloc when a considerable number of vascular anastomosis are to be made, as was suggested by several authors ${ }^{23}$. This would make the transplantation technically less demanding.

Another parameter on which the decision to transplant en bloc or after division depended was the anatomy of the urinary collecting system. Injury to the urinary collecting system has often been described as a complication of division of the renal isthmus as a treatment of ureteropelvic junction obstruction in horseshoe kidneys ${ }^{4}$. This often leads to urinary fistula formation, which is difficult to treat'. Some surgeons would let their decision whether to split or not to split depend on the morphology of the renal isthmus. When the renal isthmus is fibrous or consists of a small parenchymal mass there is a low risk of damage to the urinary collecting system or posttransplant haemorrhage after division. Although the latter complication is seen with some frequency ${ }^{24}$ it can easily be avoided by using adequate haemostatic techniques. This could be done by making a conelike excision out of the parenchymatous wound, after which the wound edges can be approximated and the renal capsula can be closed over it ${ }^{2-2}$. Two surgeons mentioned the anatomy of the veins as a factor on which their decision would depend. This seems to be very wise since there is also a great variation in the venous anatomy'.

Most surgeons would explant a horseshoe kidney en bloc $(91.2 \%)$. As suggested by some authors $^{2 \cdot}$ this seems to be the best decision. As was proposed by two surgeons it would limit the cold ischaemic time if the horseshoe kidney was split in situ. However, the disadvantage of limited overview for careful inspection of the often complex vascular anatomy would create the risk of severing renal vessels while dividing the horseshoe kidney. Most surgeons (59.8\%) were not interested in testing the anatomy of the renal isthmus and the urinary collecting system before division. All other surgeons $(40.2 \%)$ wanted to diagnose the anatomy of the urinary collecting system by retrogradely injecting either a radio-opaque contrast medium or methylene blue into the ureters or by probing the ureters. Although the renal calices of both systems are rarely connected and it hardly occurs that a calyx overrides into the contralateral part of the horseshoe kidney'., it would be wise to diagnose the anatomy of the urinary collecting system. The diagnostic procedures mentioned above are very simple and can give a good indication on the anatomical location where to divide the renal isthmus without risking urinary fistula formation.

Most surgeons (71.4\%) consider the posttransplant results of horseshoe kidneys to be equal to those of kidneys with a normal anatomy. A literature review shows that this is most likely'. Some surgeons $(23.2 \%)$ think the posttransplant results of horseshoe kidneys are worse compared to those of normal kidneys. Their opinion is probably based on the assumption that the technically demanding transplantation will cause a higher chance of primary non function based on thrombosis of one or more of the renal arteries or veins. Only a small number of surgeons $(5.4 \%)$ have the opinion that horseshoe kidneys will function better than normal kidneys. This could be true in en bloc transplanted horseshoe kidneys. Because more kidney mass (e.g. a higher number of nephrons) is transplanted into the recipient, it is to be expected that the recepients of en bloc transplanted kidneys would have lower posttransplant serum creatinine values than the recipients of a single normal kidney'. It is remarkable that no differences were seen in the opinions of the surgeons who had experience in the transplantation of horseshoe kidneys and those who did not. 


\section{CONCLUSION}

When considering the current opinions, the transplant surgeons would advise to accept a horseshoe kidney when offered for transplantation. It should have been explanted en bloc after which it can be closely inspected on the backtable. The decision to transplant it en bloc or after division of the renal isthmus depends on the morphology of the renal isthmus, the number and position of the renal vessels and/or the anatomy of the urinary collecting system. Although not advised by most surgeons, we think that it is important to diagnose the anatomy of the urinary collecting system through a retrograde pyelogram before dividing the renal isthmus. Although still no evidence exists, most transplant surgeons within the European Society for Organ Transplantation consider the results of horseshoe kidney transplantation to be equal to those of kidneys with a normal anatomy.

\section{ACKNOWLEDGEMENTS}

The authors would like to thank the members of the European Society for Organ Transplantation who participated in this study.

\section{References}

1. Bauer SB. Anomalies of the kidney and ureteropelvic junction. In: Walsh PC, Retik AB, Vaughan ED Jr, Wein AJ. eds. Campbell's urology. Philadelphia: WB Saunders, 1998: 1708-57.

2. Ratner LE. Zibari G. Strategies for the successful transplantation of the horseshoe kidney. J Urol 1993: 150: $958-60$.

3. Stroosma OB, Scheltinga MRM, Stubenitsky BM. Kootstra G. Horseshoe kidney transplantation: an overview. Clin Transplant 2000; 14: 515-9.

4. Culp OS, Winterringer JR. Surgical treatment of horseshoe kidney: Comparison of results after various types of operations. J Urol 1955: 73: 747-56.

5. Brenner BM. Cohen RA. Milford El. In renal transplantation, one size may not fit all.J Am Soc Nephrol 1992; 3:162-9. 
CHAPTER 6

\section{HORSESHOE KIDNEY TRANSPLANTATION WITHIN THE EUROTRANSPLANT REGION: A CASE CONTROL STUDY}

O.B. Stroosma, J.M.A. Smits, G.W.H. Schurink,

J. de Boer, G.G. Persijn, G. Kootstra

Accepted for publication in:

Transplantation 


\section{INTRODUCTION}

Due to the progressive shortage of cadaver organ donors, kidneys with atypical anatomy are frequently considered for transplantation. The most common anatomical variation of the kidney is the horseshoe kidney, with an incidence of one in 600 to 800 . It represents a fusion anomaly, mainly at the lower poles of the kidney, occurring between the 4 th and 6 th week of gestation. The isthmus connecting the lower poles may be a fibrous band or may contain functional parenchyma and is rarely crossed by the urinary collecting systems. Horseshoe kidneys show a great variation in origin, number and size of the renal arteries and veins. Only $30 \%$ of all horseshoe kidneys have a single renal artery to each side'. The horseshoe kidney can be transplanted en bloc or can be split and transplanted into two recipients, depending on the number of vessels and the anatomy of the urinary collecting system ${ }^{2}$. Although the results of the transplantation of horseshoe kidneys are considered good ${ }^{24}$, no in-depth study has been performed up till now. Therefore, we collected and analysed the data of the horseshoe kidneys that were donated within the Eurotransplant' region.

\section{MATERIALS AND METHODS}

A case control study was performed. All horseshoe kidneys that were donated within the Eurotransplant region were included. They were assigned to two groups: the "en bloc group" for the en bloc transplanted horseshoe kidneys and the "split group" for the horseshoe kidneys that were transplanted after division. Demographic statistics for the following variables: year of transplantation, donor age, donor sex, cause of death, cold ischaemic time, recipient age and recipient sex were performed. Data were also collected on the anatomy of the horseshoe kidney. Graft failure was defined as reinstitution of dialysis, retransplantation or death of the patient. In order to eliminate immunological influences on graft failure a second survival analysis was performed where events due to immunological failure were censored. Furthermore the association between the occurrence of primary non function and the number of renal arteries and veins was studied. Graft and patient survival were analysed up to five years after transplantation. The serum creatinine values after three months, six months and yearly upto five years posttransplantation were collected and were divided into two groups: serum creatinine $<130 \mu \mathrm{mol} / \mathrm{l}$ and serum creatinine $>130 \mu \mathrm{mol} / \mathrm{l}$, differentiating between good and impaired function.

The data of en bloc transplanted horseshoe kidneys and horseshoe kidneys that were transplanted after division were compared to each other and to a control group. For each recipient of an en bloc transplanted horseshoe kidney or a split horseshoe kidney, two matched control patients, who received a kidney with a normal anatomy, were collected from the Eurotransplant data pool'. Based on the knowledge of prognostic factors of renal transplant outcome $e^{6}$ matching was performed for the following factors: donor age, recipient age, number of previous transplantations, cold ischaemic time and year of transplantation.

Statistical analysis was performed using a chi square test. Graft and patient survival rates were estimated, using the Kaplan Meyer method. A log rank test was used for assessing differences between the groups. A p-value below 0.05 was considered significant. For the data handling SAS 6.12 (SAS Institute Inc., Cary, USA) was used. Statistical analysis were performed with SPSS 9.0 (SPSS Inc., Chicago, USA). 


\section{RESULTS}

In the period 1983 to 2000 , a total of 47 horseshoe kidneys were explanted within the Eurotransplant region. Thirteen horseshoe kidneys were discarded after explantation. The reason for this was severe atherosclerosis in one case and a complex vascular anatomy in seven cases. In five cases no reason was recorded. A total of 34 horseshoe kidneys were finally used for transplantation. Eight horseshoe kidneys were transplanted en bloc and 26 were split and transplanted into 47 recipients. Five halves of a horseshoe kidney were discarded after division. In one case this was caused by damage to the renal vessels and in two cases by the vascular anatomy that was considered too difficult for transplantation. In the remaining two cases the cause was unknown. All but three split horseshoe kidneys were transplanted within the Eurotransplant region.

The eight horseshoe kidneys in the en bloc group all had a parenchymatous isthmus. In three of the 26 horseshoe kidneys of the split group the isthmus was fibrous. The remaining 23 had a parenchymatous isthmus. All but one horseshoe kidneys had two ureters. One horseshoe kidney in the split group had three ureters. The vascular anatomy of the horseshoe kidneys and the kidneys in the control group is shown in table 6.1.

\begin{tabular}{|llll|}
\hline & N & Renal Arteries & Renal Veins \\
\hline HSK Whole organ & 34 & $4(2-8)$ & $3(2-5)$ \\
\hline HSK Transplanted En Bloc & 8 & $4(2-5)$ & $2(1-3)$ \\
\hline HSK Transplanted after split & 47 & $2(1-5)$ & $1(1-3)$ \\
\hline Control & 110 & $1(1-3)$ & $1(1-2)$ \\
\hline
\end{tabular}

TABLE 6.1:

Median number of renal arteries and veins of the horseshoe kidneys and the control group. (HSK: horseshoe kidney: N: number.

The number between parenthesis is the range).

The median donor age in the en bloc group was 48 (range 3-57) years versus 36 (range 12 $59)$ years in the split group. Four $(50 \%)$ donors in the en bloc group were female and four $(50 \%)$ were male. In the split group $5(19.2 \%)$ donors were female and $21(80.8 \%)$ donors were male. The cause of death in the en bloc group was cerebral trauma $(n=4 ; 50 \%)$ and intra cerebral bleeding $(n=4 ; 50 \%)$. In the split group the cause of death was: cerebral trauma $(n=15 ; 57.7 \%)$, intracerebral bleeding $(n=7 ; 26.9 \%)$, suicide $(n=2 ; 7.7 \%)$, cerebrovascular accident $(n=1 ; 3.8 \%)$ and postanoxic encephalopathy $(n=1 ; 3.8 \%)$. The median cold ischaemic time was 24 (range 15-48) hours in the en bloc group and 25 (range 4-61) hours in the split group. The median recipient age was 52 (range 3-59) years in the en bloc group, compared to 45 (range $23-66$ ) years in the split group. Five $(62.5 \%)$ recipients in the en bloc group were female and three $(37.5 \%)$ were male. In the split group there were 17 $(36.2 \%)$ female and $30(63.8 \%)$ male recipients. All recipients in the en bloc group received their first kidney. The mean number of previous transplantations in the split group was 0.17 (range 1-3). The mean follow-up time in the en bloc group was 39 (range 10-89) months. In the split group the mean follow-up time was 41 (range 1-166) months. 
The horseshoe kidney transplantations were compared to 110 matched 'normal' kidneys that were transplanted in the period 1983 to 1999 (median 1995). The vascular anatomy of the kidneys in the control group is shown in table 6.1. The median donor age in the control group was 39 (range 2-59) years. Thirty-seven (33.6\%) donors were female and 73 $(66.4 \%)$ were male. In the control group the cause of death was: cerebral trauma $(n=48$; $43.6 \%)$, intra cerebral bleeding ( $n=47 ; 42.7 \%)$, suicide $(n=4 ; 3.6 \%)$, cerebral tumour $(n=4$; $3.6 \%)$, cerebrovascular accident $(n=3 ; 2.7 \%)$, $C O$ intoxication $(n=1 ; 0.9 \%)$, idiopathic cerebral oedema $(n=1 ; 0.9 \%)$, postanoxic encephalopathy $(n=1 ; 0.9 \%)$ and drowning $(n=1$; $0.9 \%$ ). The median cold ischaemic time was 21 (range $3-37$ ) hours. The recipients in the control group had a median age of 47 (range 1-66) years. Thirty-seven recipients $(33.6 \%)$ were female and $73(66.4 \%)$ recipients were male. The mean number of previous transplantations of the recipients in the control group was 0.18 (range 1-3). The follow up time in the control group varied from one to 204 (median 38) months.

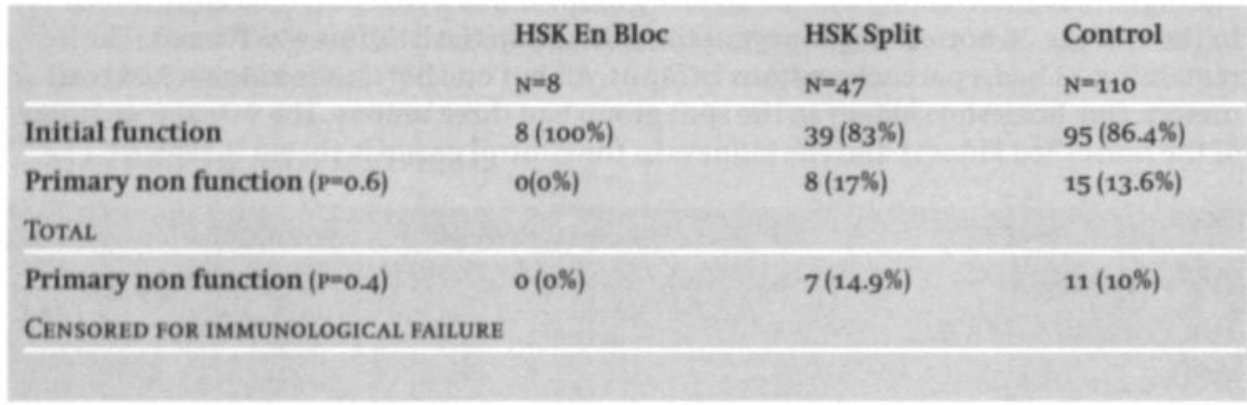

TABLE 6.2:

Short-term posttransplant results. (HSK: horseshoe kidney: N: number; Initial function: posttransplant graft function with or without the need for dialysis prior to graft function: Primary non function: the graft never functiones).

The short-term posttransplant function (initial function or primary non function) is shown in table 6.2. Primary non function was only observed in horseshoe kidneys that were transplanted after division and occurred in $17 \%$ compared to $13.6 \%$ in the control group. When censored for immunological failure, primary non function was seen in $14.9 \%$ of the split group compared to $10 \%$ of the control group. In both scenario's the differences between the three groups is not significant ( $\mathrm{p}=0.6$ and $\mathrm{p}=0.4$ respectively). Surgical complications were only seen in the split group. In three $(6.4 \%)$ cases the recipient suffered peroperative haemorrhage from the wound edges of the split horseshoe kidney. None of these three complications led to graft loss. 


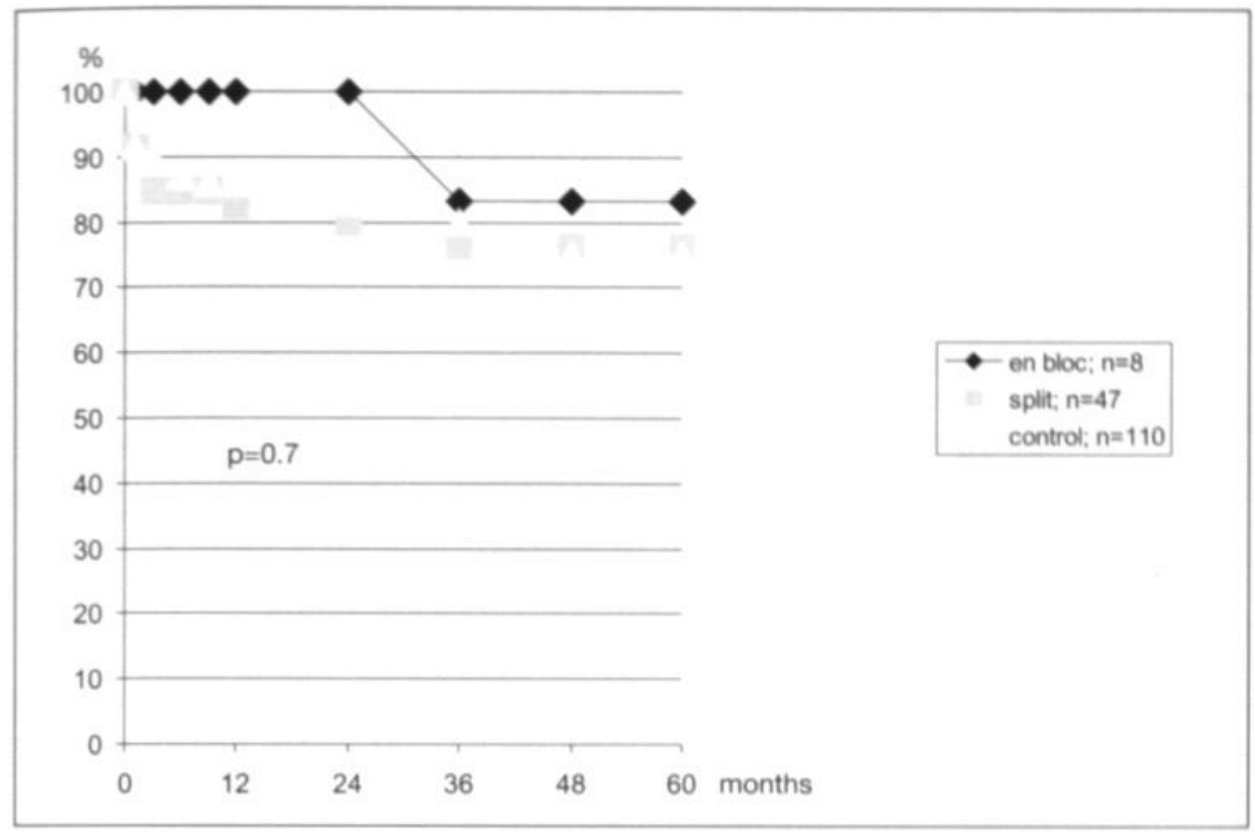

FIGURE 6.1:

Graft survival in time censored for immunological failure.

Not a single en bloc transplanted horseshoe kidney failed within the first year after transplantation. The one year graft survival in the split group was $78.6 \%$ (95\% confidence limits $66.8 \%$ and $90.3 \%$ ). The one year survival for the control group was $80.9 \%$ (95\% confidence limits $73.6 \%$ and $\mathbf{8 8 . 3 \%}$ ). When censored for immunological failure, the one year graft survival of the en bloc group was $100 \%$. For the split group and the control group it was $82.5 \%$ (95\% confidence limits $71.5 \%$ and $93.5 \%$ ) and $86.1 \%(95 \%$ confidence limits $79.6 \%$ and $92.6 \%$ ) respectively. The en bloc transplanted horseshoe kidneys had a five year graft survival of $83.3 \%$ (95\% confidence limits $53.5 \%$ and $100 \%$ ) and the divided horseshoe kidneys of $72.7 \%$ ( $95 \%$ confidence limits $59.3 \%$ and $86.2 \%$ ). The five year graft survival of the control group was $66.6 \%$ (95\% confidence limits $56.3 \%$ and $77 \%$ ). After censoring for immunological failure the five year graft survival was $83.3 \%$ (95\% confidence limits $53.5 \%$ and $100 \%$ ), $76.4 \%$ (95\% confidence limits $63.2 \%$ and $89.5 \%)$ and $75.1 \%(95 \%$ confidence limits $65.8 \%$ and $84.4 \%$ ) respectively. The differences between the three groups was not significant for the graft survival with or without censoring for immunological failure ( $\mathrm{p}=0.7$ and $\mathrm{p}=0.6$ respectively). Figure 6.1 shows the graft survival curves for the three groups after censoring for immunological failure. The patient survival curves are shown in figure 6.2. The one year patient survival rate for the en bloc group was $100 \%$. The split group had a one year patient survival rate of $97.9 \%$ (95\% confidence limits $93.7 \%$ and $100 \%)$ and the control group $94.5 \%$ (95\% confidence limits $90.3 \%$ and $98.8 \%$ ). The five year patient survival rates for the three groups was $100 \%, 92.2 \%(95 \%$ confidence limits $83.7 \%$ and $100 \%)$ and $87.2 \%(95 \%$ confidence limits $80.2 \%$ and $94.2 \%)$ respectively. The differences between the three groups were not significant ( $p=0.9$ ). 


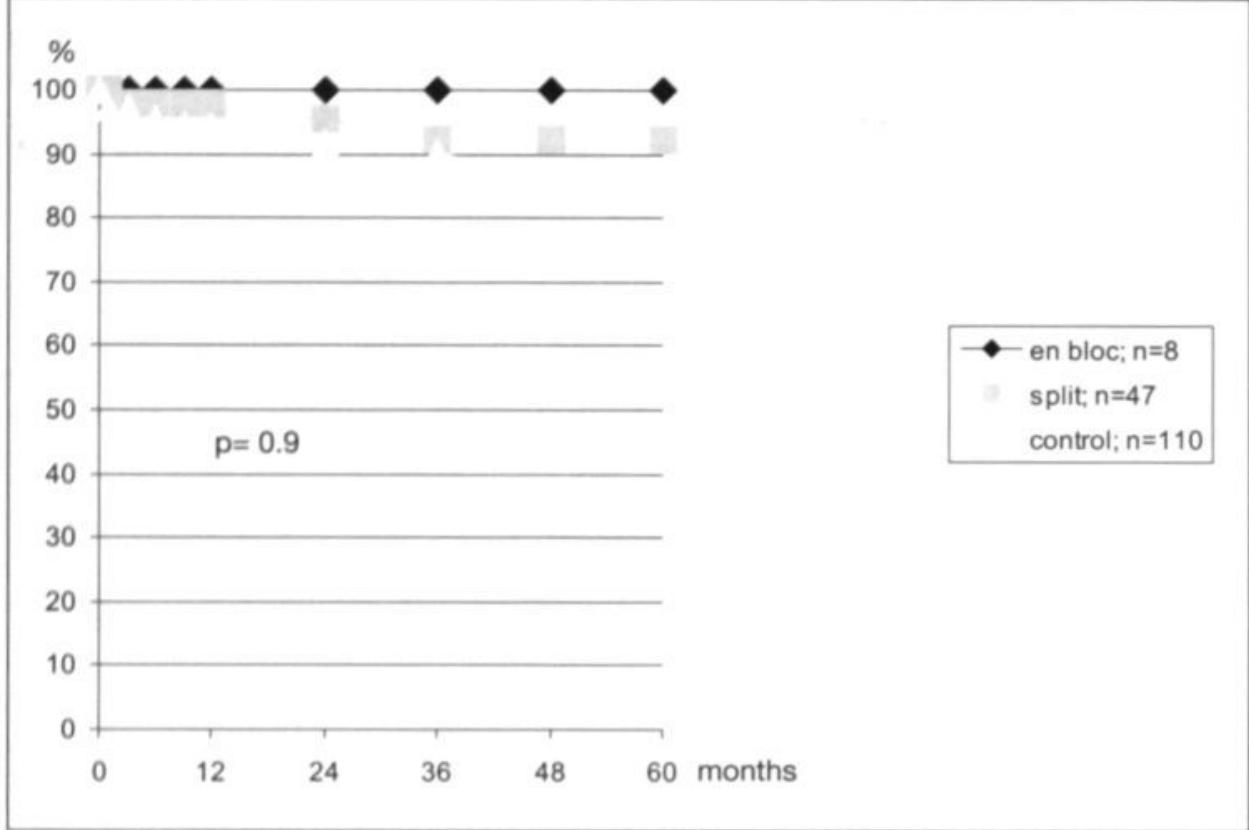

Figure 6.2:

Patient survival in time.

告

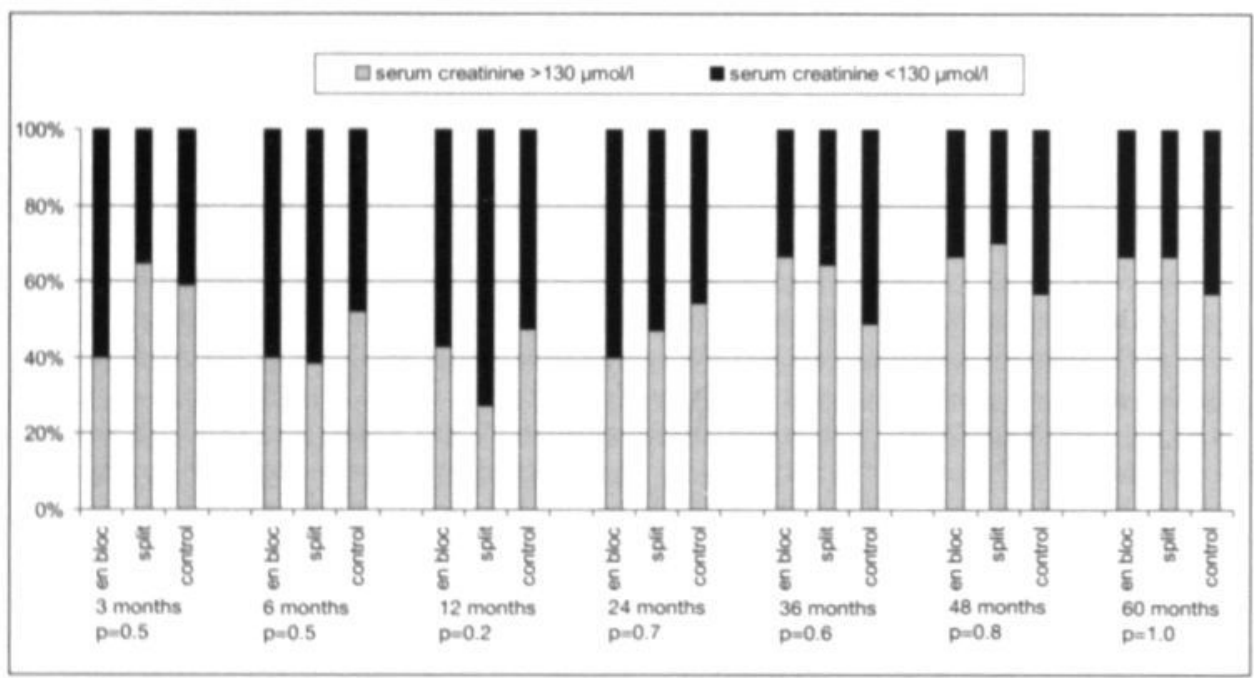

FIGURE 6.3:

Serum creatinine values of the three groups in time, as a percentage of the total. p-value is indicated below each month. 
Figure 6.3 shows the serum creatinine values of the three groups after three months, six months and one to five years. Again, no statistical significant association could be detected between the functional performance of the kidneys, assessed by serum creatinine values, of the three groups. The horseshoe kidney groups were probably too small and too variable in their vascular anatomy to give a statistical valuable ruling on the correlation between primary non function and the number of renal arteries and veins.

\section{DISCUSSION}

The first horseshoe kidney transplantation that was reported in the literature was performed by Nelson in $1975^{\prime}$. Since then. 31 cases of horseshoe kidney transplantation were reported in the world literature ${ }^{2}$. A horseshoe kidney can be transplanted en bloc, or it can be divided and transplanted into two recipients. The decision to split a horseshoe kidney depends on several factors. First of all, it depends on the number and position of renal arteries and veins ${ }^{2}$. The vascular anatomy of a horseshoe kidney can vary widely. Although an attempt has been made to classify horseshoe kidneys by their vascular anatomy", frequently occurring variations in anatomy preclude a proper classification. This variety of vascular anatomy was also seen in the horseshoe kidneys in this study. Transplantation of horseshoe kidneys can therefore be more difficult, because more and complicated vascular anastomosis are needed, especially in the transplantation of split horseshoe kidneys.

Although the results of horseshoe kidney transplantation seem to be good, there has always been a concern for primary non function based on technical failure. Of the horseshoe kidneys that were explanted, $27.7 \%$ was immediately discarded and $9.6 \%$ was discarded after division. The reason was the complex vascular anatomy in at least $53.8 \%$ and $60 \%$ respectively. It seems obvious that the number and the position of the renal arteries and veins play an important role in the decision to split a horseshoe kidney or to transplant it en bloc. The vascular anatomy of the horseshoe kidneys in this study turned out to be so variable that a proper statistical analysis of the correlation between the number of renal arteries and veins and the incidence of primary non function could not be done. Thus, from these data a recommendation whether or to split or not to split the horseshoe kidney cannot be made.

The morphology of the renal isthmus does not seem to influence the decision to split a horseshoe kidney. Although only $9 \%$ of the horseshoe kidneys had a fibrous isthmus. which is even less than the $15 \%$ reported in literature', most horseshoe kidneys $(76.5 \%)$ were divided and transplanted into two recipients. Division should be done on a backtable after en bloc explantation and careful inspection of the vascular anatomy and the urinary collecting system ${ }^{2 .}$. It is important not to injure the urinary collecting system when dividing the horseshoe kidney. This can lead to urinary fistula formation. Although this was not described in this study, this complication has been reported after division of the renal isthmus as a treatment of ureteropelvic junction obstruction in horseshoe kidneys ${ }^{10.1}$. Severing of the urinary collecting system can be avoided by visualising it. This can be done by making an X-ray after retrograde injection of a contrast medium into the ureters. When the urinary collecting systems of both sides are not connected and do not override into the contralateral part of the horseshoe kidney, the isthmus can be safely divided ${ }^{2}$. Another complication of division of the renal isthmus is haemorrhage from the parenchymatous wound. Only $6.4 \%$ of the recipients of a split horseshoe kidney in this study suffered peroperative haemorrhage. When division of the renal isthmus is contra-indicated, the horseshoe kidney should be transplanted en bloc. Technically this procedure is not different from the transplantation of paediatric en bloc kidneys into adult recipients ${ }^{12}$. 
The differences in occurrence of primary non function between the en bloc transplanted horseshoe kidneys $(0 \%)$, the horseshoe kidneys that were divided before transplantation (17\%) and the control group (13.6\%) were not significant. Even when these results were censored for immunological failure and only the cases of primary non function caused by technical failure or unclear reasons were analysed, the differences between the three groups were still not significant, as is shown in table 6.2. This demonstrates that, although the transplantation of horseshoe kidneys seems to be technically more challenging, the short-term results were not jeopardized.

The long-term results (one to five year graft and patient survival and serum creatinine values) showed no significant differences in graft survival upto five years $(\mathrm{p}=0.6)$. Even when the graft survival was censored for immunological failure there were still no significant differences between the three groups ( $\mathrm{p}=0.7$ ). The patient survival upto five years did not show any significant differences between the three groups either $\left(p^{=0.9}\right)$. Because most problems in horseshoe kidney transplantation are to be expected in the initial postoperative phase, the long-term results should be equal to those of kidneys with a normal anatomy. as illustrated by our own results.

Because more kidney mass (e.g. a higher number of nephrons) is transplanted into the recipients of en bloc transplanted horseshoe kidneys, it is to be expected that the en bloc transplanted kidneys would have lower posttransplant serum creatinine values than the recipients in the split group or the control group ${ }^{6.13}$. The same theory is applied in double kidney transplantations from elder donors" ${ }^{14}$. With respect to the evaluation of the functional capacity of the allografts, serum creatinine values were analysed in the three groups. After three months there is a higher percentage of recipients with a serum creatinine value under $130 \mu \mathrm{mol} / \mathrm{l}$ in the en bloc transplanted horseshoe kidneys than in the split group or the control group ( $60 \%$ versus $35.1 \%$ and $40.9 \%$ respectively). However, this difference is not significant ( $\mathrm{p}=0.5$ ). As is shown in figure 6.3, the differences between the three groups become smaller after three months and no significant differences could be found.

\section{CONCLUSION}

This study shows that the transplantation of horseshoe kidneys, either en bloc or split. yield the same short-term as well as long-term results as the transplantation of kidneys with a normal anatomy. Hence the concerns about horseshoe kidney transplantation are not justified. However, it must be noted that the transplantation of horseshoe kidneys remains technically challenging and should therefore be kept in experienced hands. Because of the shortage of donors, horseshoe kidneys can and should be used as a save source for organ donation.

\section{ACKNOWLEDGEMENTS}

The authors would like to thank the participating centers within the Eurotransplant region for providing the necessary data. We would also like to thank Prof. Dr. G. Opelz for the opportunity to use the Collaborative Transplant Study (CTS) database in Heidelberg. Germany.

\section{FOOTNOTE}

A.

Eurotransplant is an organ exchange organization in which donor hospitals, tissue typing laboratories and transplant centers in Austria. Belgium. Germany.

Luxembourg. Slovenia and the Netherlands collaborate. 


\section{References}

1. Bauer SB. Anomalies of the kidney and ureteropelvic junction. In: Walsh PC, Retik AB, Vaughan ED Jr, Wein AJ. eds. Campbell's urology. Philadelphia: WB Saunders, 1998: 1708-57.

2. Stroosma OB, Scheltinga MRM. Stubenitsky BM, Kootstra G. Horseshoe kidney transplantation: An overview. Clin Transplant 2000; 14: 515-9.

3. Ratner LE, Zibari G. Strategies for the successful transplantation of the horseshoe kidney. J Urol 1993: 150:958-60.

4. Vromen MAM, van der Vliet JA, Ruers TJM. Muller GH, Kootstra G. Use of horseshoe kidneys for transplantation. Neth J Surg 1986; 38: $183-6$.

5. Neter J. Wasserman W, Kutner MH. Applied linear statistical models: regression, analysis of variance and experimental designs. Boston: Irwin Inc, 1990.

6. Smits JMA, van Houwelingen HC, De Meester J. et al. Permanent detrimental effect of non immunological factors on long-term renal graft survival. A parsimonious model of timedependency. Transplantation 2000: 70:317.23.

7. Nelson RP. Palmer JM. Use of horseshoe kidney in renal transplantation: technical aspects. Urology 1975; 6:357-9.

8. Graves FT. The arterial anatomy of the congenitally abnormal kidney. Br J Surg 1969; 56: 533-41.

9. Farman F. Fusion anomalies of the kidney. In: Alken CE, Dix VW, Goodwin WE, Weyrauch HM, Wildbolz E eds. Encyclopedia of urology, Vol.VII/I. New York: Springer-Verlag. 1968: 66-72.

10. Dajani AM. Horseshoe kidney: a review of twentynine cases. Br J Urol 1966; 37: 388-402.

11. Culp OS, Winterringer JR. Surgical treatment of horseshoe kidney: comparison of results after various types of operations. J Urol 1955; $73: 747-56$.

12. Hobart MG, Modlin CS. Kapoor A, Boparai N. Mastroianni B, Papajcik D, Flechner SM, Goldfarb DA, Fischer R. O'Malley KJ. Novick AC. Transplantation of pediatric en bloc cadaver kidneys into adult recipients.

Transplantation 1998; 66: 1689-94.

13. Brenner BM. Cohen RA, Milford EL. In renal transplantation, one size may not fit all. J Am Soc Nephrol 1992:3:162.9

14. Andrés A. Morales JM. Herrero JC, Praga M. Morales E, Hernandez E, Ortuno T, Rodicio JL, Martinez MA, Usera G. Diaz R. Polo G. Aguirre F, Leiva O. Double versus single renal allografts from aged donors. Transplantation 2000: 69: $2060-6$. 
ss 
CHAPTER 7

\section{TRANSPLANTING HORSESHOE KIDNEYS:}

\section{A WORLDWIDE SURVEY}

O.B. Stroosma, G.W.H. Schurink,

J.M.A. Smits, G. Kootstra

Accepted for publication in:

The Journal of Urology 


\section{INTRODUCTION}

The horseshoe kidney is the most common renal anatomical variation with an incidence of one in 600 to $800^{1}$. It occurs twice as often in men as in women and arises during the 4 th to 6 th week of human development, by fusion of the metanephrogenic caps of usually the lower poles. The isthmus connecting the lower poles may be a fibrous band or may contain functional parenchyma and is rarely crossed by the collecting systems. The vascular anatomy of the horseshoe kidney is usually very complex. The renal arteries and veins may show great variation in origin, number and size. Only $30 \%$ of horseshoe kidneys have one renal artery to each side'. Due to the organ shortage, horseshoe kidneys are also considered for transplantation. They can be transplanted en bloc into one recipient, or after division of the renal isthmus into two recipients. Some authors have tried to make recommendations on the transplantation of horseshoe kidneys and whether to divide them or not ${ }^{2 x .4}$. However, these recommendations were based on case reports only. The aim of this study is to give a recommendation on the transplantation of horseshoe kidneys based on a worldwide survey.

\section{MATERIALS AND METHODS}

A total of 438 transplantation clinics and transplantation foundations in 38 countries were contacted and asked if they had any knowledge of horseshoe kidney transplantations being performed in their unit or region. When a case of horseshoe kidney transplantation was found, the surgeons who were involved in the donation and transplantation of the horseshoe kidney were sent a questionnaire. All cases found in literature were also included' and the authors were send a questionnaire for additional data. The study cases were assigned to two groups: en bloc transplanted horseshoe kidneys (en bloc group) and horseshoe kidneys that were transplanted after division (split group).

The following variables were studied: donor age, donor sex, cause of death, cold ischaemic time, recipient age and recipient sex. Data were also collected on the anatomy of the horseshoe kidney and the posttransplant complications. The incidence of primary non function was analysed in a logistic regression model. In a first model all occurrences of primary non function were calculated as an event. In a second model primary non function due to immunological reasons were censored. Likelihood ratio tests were performed to analyse the influence of the number of arteries and veins on the probability of occurrence of primary non function in the split group ${ }^{6}$. A p-value below 0.05 was considered significant. For data handling SAS 6.12 (SAS Institute Inc., Cary, USA) was used. Statistical analysis were performed with SPSS 9.0 (SPSS Inc., Chicago, USA).

\section{RESULTS}

In the period of 1975 to 2000 a total of 80 horseshoe kidney allografts were available for transplantation. The horseshoe kidneys were transplanted in 69 centers in 22 countries. Table 7.1 shows the countries in which the horseshoe kidneys were donated and transplanted. All but three were obtained from cadaveric donors. Two cases of living donation after in situ division of the renal isthmus were reported and one case of autotransplantation of a fragment of a horseshoe kidney after a trauma. Twenty-three horseshoe kidneys were transplanted en bloc. The decision to transplant them en bloc was based on: complex vascular anatomy $(n=5)$, thick parenchymatous isthmus $(n=4)$ and a paediatric donor $(n=4)$. In one case only one recipient could be found due to an $A B$ bloodtype of the donor and in nine cases the reason was not reported. Division of the renal isthmus was performed in $\mathbf{5 7}$ horseshoe kidneys and they were transplanted into 97 recipients. Seventeen halves of a horseshoe kidney were not used for transplantation after division. 


\begin{tabular}{|c|c|c|c|}
\hline Country & HSK donors & $\begin{array}{l}\text { Recipients of } \\
\text { 'en bloc' HSK }\end{array}$ & $\begin{array}{l}\text { Recipients of } \\
\text { 'split' HSK }\end{array}$ \\
\hline AustrauA & 4 & 2 & 3 \\
\hline AUSTRIA & 6 & 2 & 6 \\
\hline BeLGiUM & 5 & 3 & 1 \\
\hline BrazIL & 4 & 2 & 4 \\
\hline Canada & 1 & o & 2 \\
\hline CZECH REPUBLIC & 2 & 1 & 2 \\
\hline FRANCE & 3 & o & 5 \\
\hline GERMANY & 19 & 4 & 31 \\
\hline IRELAND & 1 & o & 2 \\
\hline ItaLY & 2 & o & 4 \\
\hline JAPAN & 1 & o & 1 \\
\hline LIBANON & 1 & 1 & o \\
\hline LUXEMBOURG & o & o & 3 \\
\hline NorWAY & 2 & o & 2 \\
\hline PAKISTAN & 0 & o & 2 \\
\hline PORTUGAL & 1 & o & 1 \\
\hline ROMANIA & 1 & 0 & 1 \\
\hline SAUdi ARABLA & o & o & 1 \\
\hline SPAIN & 3 & 1 & 3 \\
\hline THE NetherLands & 5 & o & 3 \\
\hline UNITED KINGDOM & 2 & o & 3 \\
\hline UNITED States OF AMERICA & 17 & 7 & 17 \\
\hline Total. & 80 & 23 & 97 \\
\hline
\end{tabular}

TABLE 7.1:

Number of donors and recipients of en bloc and split horseshoe kidneys by country. (HSK: horseshoe kidney) 
The reasons for this were: complex vascular anatomy $(n=6)$, injury to the urinary collecting system $(n=1)$, no recipient found $(n=1)$, living donation $(n=2)$ and autotransplantation $(n=1)$. One half of a horseshoe kidney was discarded after the contralateral half showed acute vascular thrombosis immediately after reperfusion of the graft. In five cases the reason was not reported.

All en bloc transplanted horseshoe kidneys had a parenchymatous renal isthmus. In the split group $44(77.2 \%)$ horseshoe kidneys had a parenchymatous isthmus, eight $(14.0 \%)$ had a fibrous isthmus and in $5(8.8 \%)$ cases the morphology of the renal isthmus was not reported. All but one horseshoe kidney had two ureters. This horseshoe kidney in the split group had three ureters. After explantation the anatomy of urinary collecting system of the horseshoe kidneys was diagnosed by inspection in all of the en bloc transplanted horseshoe kidneys, revealing one case of an overriding calyx into the contralateral part. The anatomy of the urinary collecting system of most of the horseshoe kidneys in the split group was diagnosed by inspection $(n=50)$. Other modalities used to diagnose the anatomy of the urinary collecting system were: retrograde injection of a radio-opaque contrast medium into the ureters $(n=3)$, injection of methylene blue into the ureters $(n=1)$ and ultrasound $(n=1)$. In both cases of living donation the preoperative diagnostic modalities used in the donor were: intravenous pyelography, computed tomography and arteriography. One horseshoe kidney in the split group was reported to have a continuous urinary collecting system, which was discovered after division of the renal isthmus. An overriding calyx into the contralateral part of the horseshoe kidney was reported in two cases in the split group. The vascular anatomy of the horseshoe kidneys of both groups is shown in table 7.2. The number of renal arteries and veins of one horseshoe kidney in the split group was not reported.

\begin{tabular}{|llll|}
\hline & N & Renal Arteries & Renal Veins \\
\hline HSK Whole organ & 80 & $4(2-8)$ & $2(1-6)$ \\
\hline HSK Transplanted en bloc & 23 & $5(2-7)$ & $3(1-5)$ \\
\hline HSK Transplanted after division & 97 & $2(1-5)$ & $1(1-6)$ \\
\hline
\end{tabular}

TABLE 7.2:

Median number of renal arteries and veins of the horseshoe kidneys.

(HSK: horseshoe kidney; $\mathrm{N}$ : number. The number between parenthesis is the range).

The median donor age in the en bloc group was 29 (range 1-65) years and in the split group it was 30 (range $12-59$ ) years. Six $(26.1 \%)$ donors in the en bloc group were female and $17(73.9 \%)$ were male. In the split group $12(21.2 \%)$ donors were female and $45(78.9 \%)$ were male. The cause of death in the en bloc group was: cerebral trauma $(n=9 ; 39.1 \%)$. intracerebral bleeding $(n=7: 30.4 \%)$. cerebrovascular accident $(n=2: 8.7 \%)$, postanoxic encephalopathy $(n=1 ; 4.3 \%)$ and hypoglycaemia $(n=1 ; 4.3 \%)$. In three $(13.0 \%)$ cases the cause of death was not reported. In the split group the cause of death of the 54 cadaveric donors was: cerebral trauma $(\mathrm{n}=28 ; 51.9 \%)$, intracerebral bleeding $(\mathrm{n}=12 ; 22.2 \%)$, suicide $(n=2: 3.7 \%)$, postanoxic encephalopathy $(n=2: 3.7 \%)$ and cerebrovascular accident $(n=1$ : $1.9 \%)$. The cause of death was not reported in nine $(16.7 \%)$ cases. The median cold ischaemic time in the en bloc group was 24 (range 9-48) hours. In the split group the median cold ischaemic time was 22 (range 2-61) hours. The median recipient age was 49 (range 3-59) years for the en bloc group and 44 (range 7-69) years for the split group. Ten $(43.5 \%)$ recipients in the en bloc group were female and $13(56.5 \%)$ were male. In the split group $38(39.2 \%)$ recipients were female and $53(54.6 \%)$ were male. In six $(6.2 \%)$ cases the recipient sex was not reported. 
Postoperative complications were seen in three $(13.0 \%)$ recipients in the en bloc group. and they consisted of: ureter necrosis $(n=2)$ and ureteral lithiasis $(n=1)$. In the split group $11(11.3 \%)$ recipients suffered postoperative complications: sepsis $(n=2)$, urinary fistula formation $(n=2)$, ureterocystostomy stenosis $(n=2)$ and adult respiratory distress syndrome $(n=1)$. Postoperative haemorrhage from the parenchymal wound edges was seen in five recipients. In three of these patients re-exploration was required and in one patient this led to graft loss.

\begin{tabular}{|c|c|c|c|c|c|c|}
\hline \multirow[b]{2}{*}{$\begin{array}{l}\text { Number of renal arteries } \\
\text { or veins }\end{array}$} & \multicolumn{3}{|c|}{ Renal arteries } & \multicolumn{3}{|c|}{ Renal Veins } \\
\hline & Total & PNF & PNFI & Total & PNF & PNF-I \\
\hline 1 & 27 & 5 & 3 & 66 & 10 & 8 \\
\hline 2 & 42 & 7 & 7 & 22 & 2 & 2 \\
\hline 3 & 23 & 1 & 1 & 7 & 1 & 1 \\
\hline 4 & 3 & o & o & o & n.a. & n.a. \\
\hline 5 & 1 & o & o & o & n.a. & n.a. \\
\hline 6 & o & n.a. & n.a. & 1 & o & o \\
\hline p-value & n.a. & 0.1 & 0.3 & n.a. & 0.7 & 0.9 \\
\hline
\end{tabular}

\section{TABLE 7.3:}

The occurrence of primary non function of the whole group and after censoring for immunological failure in relation to the number of renal arteries and veins in the split group (PNF: primary non function; PNF-I: primary non function censored for immunological failure; n.a.: not applicable. The vascular anatomy was not reported in one case).

Primary non function was seen in one $(4.3 \%)$ recipient in the en bloc group and in 13 $(13.4 \%)$ recipients in the split group. In two cases the primary non function was caused by acute rejection and in the other cases the reason was technical failure due to: thrombosis of the renal artery $(n=7)$, poor condition of the recipients own vascular system $(n=2)$, dissection of the renal artery $(n=1)$, haemorrhage of a ruptured allograft $(n=1)$ and ureter stenosis $(\mathrm{n}=1)$. Table 7.3 shows the occurrence of primary non function in relation to the number of renal arteries and veins in the split group. There is no significant rise in probability of the occurrence of primary non function with the increase in the number of renal arteries or veins in the whole group (p-values 0.1 and 0.7 respectively) or after censoring for immunological failure (p-values 0.3 and 0.9 respectively).

The median follow-up was 14 (range 1-26) months in the en bloc group and 24 (range 0 $166)$ months in the split group. The median serum creatinine value at longest follow-up for both groups was 90 (range 53-256) $\mu \mathrm{mol} / \mathrm{l}$ and 150 (range 65-400) $\mu \mathrm{mol} / \mathrm{l}$ respectively. 


\section{DISCUSSION}

Two thirds of the horseshoe kidneys show complications based on ureteropelvic junction obstruction, such as hydronephrosis, renal calculi and recurrent urinary tract infections'. Therefore the medical history of a donor with a horseshoe kidney should always be studied before explantation. Transplantation of horseshoe kidneys can be done after division of the renal isthmus or en bloc. The latter is technically similar to the en bloc transplantation of paediatric kidneys into adult recipients'. This study shows that the short-term posttransplant results for both groups were good; $95.7 \%$ of the recipients in the en bloc group and $86.6 \%$ of the recipients in the split group showed initial function of the kidney. The median serum creatinine values at longest follow up ( 90 and $150 \mu \mathrm{mol} / \mathrm{l}$ respectively) can also be considered good. Although an under-reporting of failed cases might flatter these results, they seem to be similar to the posttransplant results of kidneys with a normal anatomy".

The decision to transplant a horseshoe kidney en bloc depended on several factors: donor age, the morphology of the renal isthmus and the vascular anatomy. The en bloc transplantation of paediatric kidneys with a normal anatomy into adult recipients has been widely accepted"s. In this study the young donor age had been the reason to transplant the horseshoe kidney en bloc in four cases. The small nephron mass in these paediatric donors, in relation to the nephron mass needed in the adult recipients was thus compensated. The en bloc transplantation of a paediatric horseshoe kidney could even be technically less complicated. The torsion of the kidneys around the renal vessels, which often happens during the en bloc transplantation of paediatric kidneys with a normal anatomy, will occur less frequently in the en bloc transplantation of a horseshoe kidney. To compensate for the decline of functional nephrons with age, the en bloc transplantation of kidneys from elder donors has been suggested ${ }^{10 .}$. . Although in the present study a high donor age has not been a reason to transplant a horseshoe kidney en bloc, it could be considered when a horseshoe kidney is found in an elderly donor.

The renal isthmus connecting both poles of a horseshoe kidney is mostly made of functional parenchyma. In this study $14 \%$ of the horseshoe kidneys had a fibrous isthmus. which is similar to the rate reported in literature'. In four cases the thick parenchymal bridge was mentioned as the reason to transplant the horseshoe kidney en bloc.

However, with the use of adequate haemostatic techniques, posttransplantation haemorrhage from the parenchymal wound, after division of the renal isthmus, can be avoided. It is recommended to make a conelike excision of the parenchyma so the wound edges can be brought together and the renal capsula can be closed over it. Three horseshoe kidneys were reported to have an overriding calyx into the contralateral part of the horseshoe kidney. In one horseshoe kidney a continuous urinary collecting system was reported. In our opinion the only embryological explanation for this can be that not only the metanephrogenic caps, but also the ureteric buds of both sides fuse. When a horseshoe kidney of which the urinary collecting system crosses the midline is divided, one or more calyces will be severed. This can be complicated by urinary fistula formation. Urinary fistula formation was often reported after the division of horseshoe kidneys as a therapy for ureteropelvic junction obstruction, and proved difficult to treat ${ }^{12}$. In the present study this complication was observed after the division of two horseshoe kidneys with a urinary collecting system that crossed the midline. This complication should be avoided by en bloc transplantation of horseshoe kidneys with a urinary collecting system that crosses the midline. Although only performed in a minority of cases we would advise to diagnose the anatomy of the urinary collecting system. when division of the renal isthmus is considered. In our experience this can easily be done by retrogradely injecting a radiopaque contrast medium into the ureters followed by a renogram. as was done in three cases. 
The vascular anatomy of the horseshoe kidney is usually very complex, as is shown in table 7.2. Not only the number, but also the position of the renal arteries and veins can show a lot of variation. It is not unusual for renal vessels to originate from the iliac arteries and veins and the renal isthmus frequently has it's own blood supply. Although attempts to classify the vascular anatomy have been made ${ }^{12}$ is the frequently occurring variations in origin, number and size preclude a proper classification. This variation in vascular anatomy makes the transplantation of split horseshoe kidneys technically more demanding because more complicated vascular anastomosis are needed. This could be reflected on the short-term posttransplant results, because technical surgical problems are one of the risk factors for primary renal graft thrombosis ${ }^{16}$. However, in contrast to our expectations, the results from our study show that the number of renal arteries or veins alone has no influence on the probability of the occurrence of primary non function not due to immunological failure. The reason for this is probably a combination of three factors. The results shown in table 7.3 are probably biased because a complicated transplantation like this is likely to be performed by the most experienced transplant surgeon of the concerning center. These experienced transplant surgeons have probably based their decisions whether to split or not to split not only on the number of renal arteries and veins, but also on their position and size. Finally, because the differences in short-term posttransplant results between the groups with increasing numbers of renal arteries and veins are not significant and the general posttransplant results are considered good, we can conclude that the right decision has been made in most cases.

\section{RECOMMENDATIONS}

A flowdiagram for the transplantation of horseshoe kidneys is shown in figure 7.1. When the medical history of the donor does not reveal complaints related to ureteropelvic junction obstruction, the horseshoe kidney should be explanted en bloc, allowing careful inspection on the backtable. After retrogradely injecting a contrast medium into the ureters a renogram can be made. When the urinary collecting system crosses the midline, the horseshoe kidney should be transplanted en bloc. When the urinary collecting system does not cross the midline, the vascular anatomy of the horseshoe kidney should be closely inspected. When the number and position and size of renal arteries and veins is judged to cause a high risk of technical failure, the horseshoe kidney should be transplanted en bloc. When the risk of technical failure is thought to be low, the horseshoe kidney can be split. To avoid postoperative haemorrhage from the parenchymal wound. adequate haemostasis should be obtained as mentioned above. Because of the technical challenge, the transplantation of horseshoe kidneys should stay in experienced hands.

\section{ACKNOWLEDGEMENTS}

The authors would like to thank all the participating transplantation centres and transplantation foundations for providing the necessary data. 


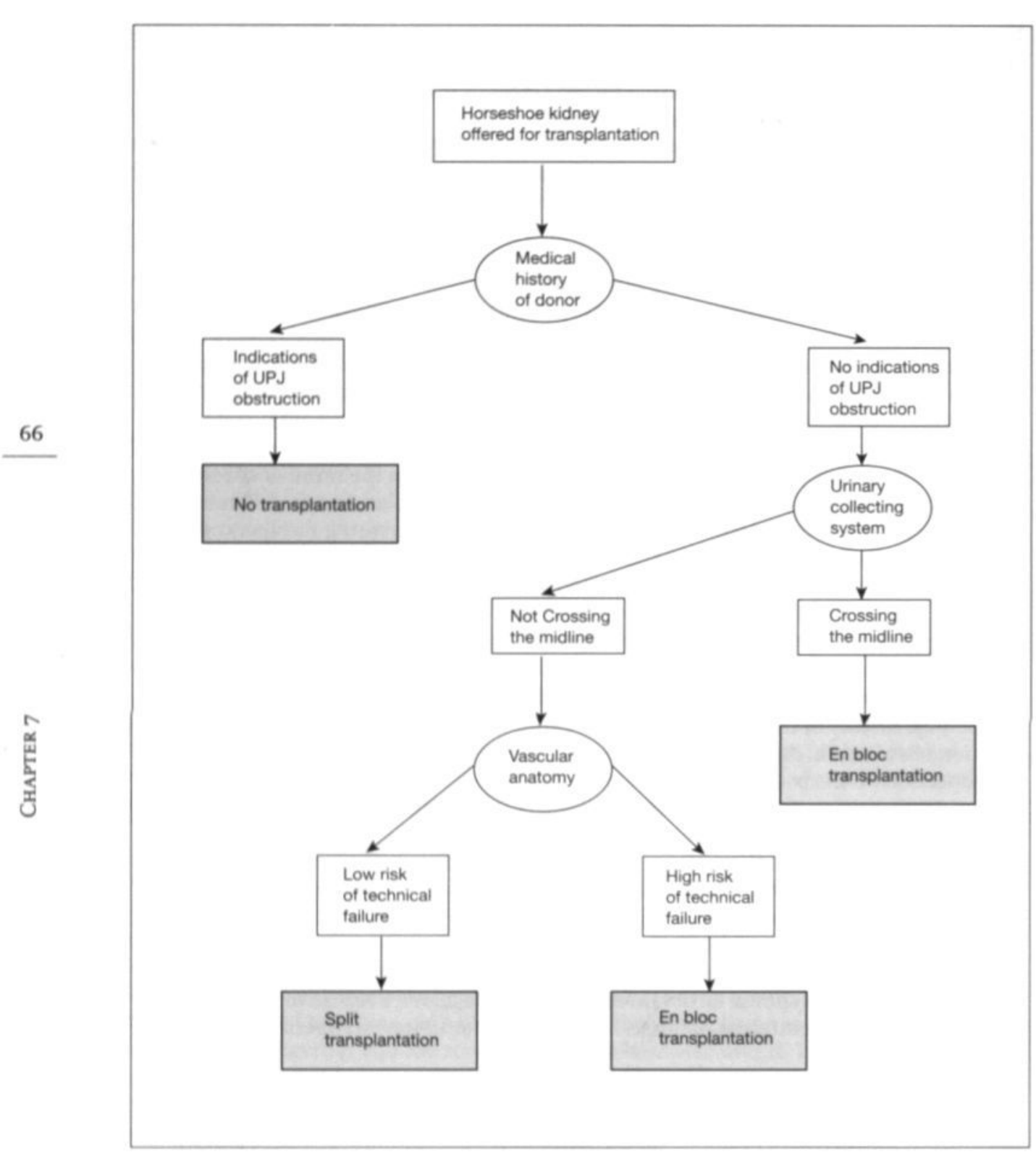

Figure 7.1:

Flow diagram for the decision between en bloc and split transplantation of a horseshoe kidney. (UPJ: Ureteropelvic junction) 


\section{References}

1. Bauer SB. Anomalies of the kidney and ureteropelvic junction. In: Walsh PC, Retik AB, Vaughah ED Jr, Wein AJ. eds. Campbell's urology. Philadelphia: WB Saunders, 1998: 1708-57.

2. Ratner LE, Zibari G. Strategies for the successful transplantation of the horseshoe kidney. J Urol 1993; $150: 958-60$.

3. Vromen MAM, van der Vliet JA, Ruers TJM. Muller GH. Kootstra G. Use of horseshoe kidneys for transplantation. Neth J Surg 1986: 38: 1836.

4. Hayes JM. The transplantation of difficult donor kidneys and recipients: helpful surgical techniques. JUrol 1993: 149: 250-4.

5. Stroosma OB, Scheltinga MRM. Stubenitsky BM, Kootstra G. Horseshoe kidney transplantation: an overview. Clin Transplant 2000; 14:515-9.

6. Neter J. Wasserman W, Kutner MH. Applied linear statistical models: regression, analysis of variance and experimental designs. Boston: Irwin Inc, 1990.

7. Hobart MG, Modlin CS. Kapoor A. Boparai N, Mastroianni B, Papajcik D. Flechner SM, Goldfarb DA, Fischer R. O'Malley KJ. Novick AC. Transplantation of pediatric en bloc cadaver kidneys into adult recipients. Transplantation 1998: 66: 1689-94.

8. Stroosma OB, Smits JMA. Schurink GWH, de Boer J. Persijn GG, Kootstra G. Horseshoe kidney transplantation within the Eurotransplant region: a case control study. Transplantation. In Press.

9. Petritsch PH. Colombo T, Wirnsberger GH. Zitta S. Ratschek M. Gute Langzeitfunktion von transplantierten Săuglingsnieren in Erwachsene. Acta Chir Austriaca 2000: 32 Suppl 170: \$5.

10 Brenner BM, Cohen RA, Milford EL In renal transplantation, one size may not fit all.J Am Soc Nephrol 1992:3: 1629.

11. Andrés A, Morales JM, Herrero JC. Praga M. Morales E. Hernandez E, Ortuno T, Rodicio JL. Martinez MA. Usera G. Diaz R. Polo G. Aguirre F. Leiva $O$. Double versus single renal allografts from aged donors. Transplantation 2000: 69: 2060-6.

12. Dajani AM, Horseshoe kidney: a review of twenty-nine cases. Br J Urol 1966: 37: 388-402.

13. Culp OS, Winterringer JR. Surgical treatment of horseshoe kidney: comparison of results after various types of operations. J Urol 1955; 73: 747-56.

14. Graves FT. The arterial anatomy of the congenitally abnormal kidney. Br J Surg 1969; 56: 533-41.

15. Boatman DL., Cornell SH, Kolln CP. The arterial supply of horseshoe kidneys. Am J Roentgenol Rad Nuc Med 1971: 113: 447-51.

16. Bakir N, Sluiter WJ. Ploeg RJ. van Son WJ. Tegzess AM. Primary renal graft thrombosis. Nephrol Dial Transplant 1996: 11: 140-7. 
68 


\section{CASE REPORTS}

Successful transplantation of a divided horseshoe kidney following prolonged donor hypotension and long distance transportation: a case report

O.B. Stroosma, M.R.M. Scheltinga, L.H.J.M. van den Akker,

S.A.H. Rizvi, S.A.A. Naqvi, G. Kootstra

Published in:

Transplant International 2001; 14: 56-7.

Transplanting horseshoe kidneys:

the Maastricht experience

O.B. Stroosma, G. Kootstra

Published in:

Transplantation Proceedings 2000; 32: 1602-3. 


\section{CASE 1}

A 16-year-old male (blood group AB, Rhesus positive) without a history of urinary tract disease (Blood urea nitrogen $3.3 \mathrm{mmol} / \mathrm{l}$; serum creatinine $82 \mu \mathrm{mol} / \mathrm{l}$ ) was diagnosed braindead after a severe cerebral trauma. Permission for organ donation was granted by the family. In spite of adequate infusion and inotropic support, hypotension due to excessive capital blood loss persisted for almost 3 hours. The maximum systolic blood pressure was $60 \mathrm{mmHg}$. A Double-Balloon-Triple-Lumen catheter was inserted into the right common iliac artery after an abdominal incision, and perfusion with University of Wisconsin solution was started. A horseshoe shaped kidney was explanted following a standard surgical approach. Inspection revealed a single vein and ureter on each side. The right side had one main and one accessory artery. One artery was present on the left side. Macroscopically the isthmus contained normal parenchyma. A radiopaque contrast medium was retrogradely injected into both ureters, revealing two separate urinary collecting systems (figure 8.1). The horseshoe kidney was divided sharply through the isthmus and the two halves were perfused in a Gambro ${ }^{\text {Bac }}$ preservation machine for viability testing. Established parameters indicated that both halves of the horseshoe kidney were suitable for transplantation'. The AB bloodtype was an obstacle for finding recipients within the Eurotransplant exchange programme so the kidneys were offered to the Sindh Institute of Urology and Transplantation in Karachi, Pakistan, where they were accepted. Both halves were transported to Pakistan while still being machine perfused.

After a cold ischaemic time (CIT) of 59 hours, the left side of the kidney was transplanted into a 35-year-old female with end stage renal failure of an unknown origin. She had 5 HLA mismatches. The renal artery was anastomosed to the external iliac artery. Reperfusion was good and the second warm ischaemic time (WTT2) was 55 minutes. Diuresis started 4 days post-operatively, and haemodialysis was stopped after 11 days. A graft biopsy, obtained one month after transplantation showed no signs of rejection. Her serum creatinine was $162 \mu \mathrm{mol} / \mathrm{l}$ two months after transplantation.

The right side of the kidney was transplanted into a 45-year-old female who suffered from end stage renal failure due to hypertension. She also had 5 HLA mismatches. The cold ischaemic time (CIT) was 61 hours. The renal and the accessory artery were anastomosed to the external iliac artery. Reperfusion was good and the second warm ischaemic time (WTT2) was 81 minutes. Function was delayed and first diuresis was observed 7 days after transplantation. In this patient haemodialysis was discontinued at day 14 . A graft biopsy was not taken. Two months after transplantation she developed a respiratory tract infection, leading to a septic shock and death. 


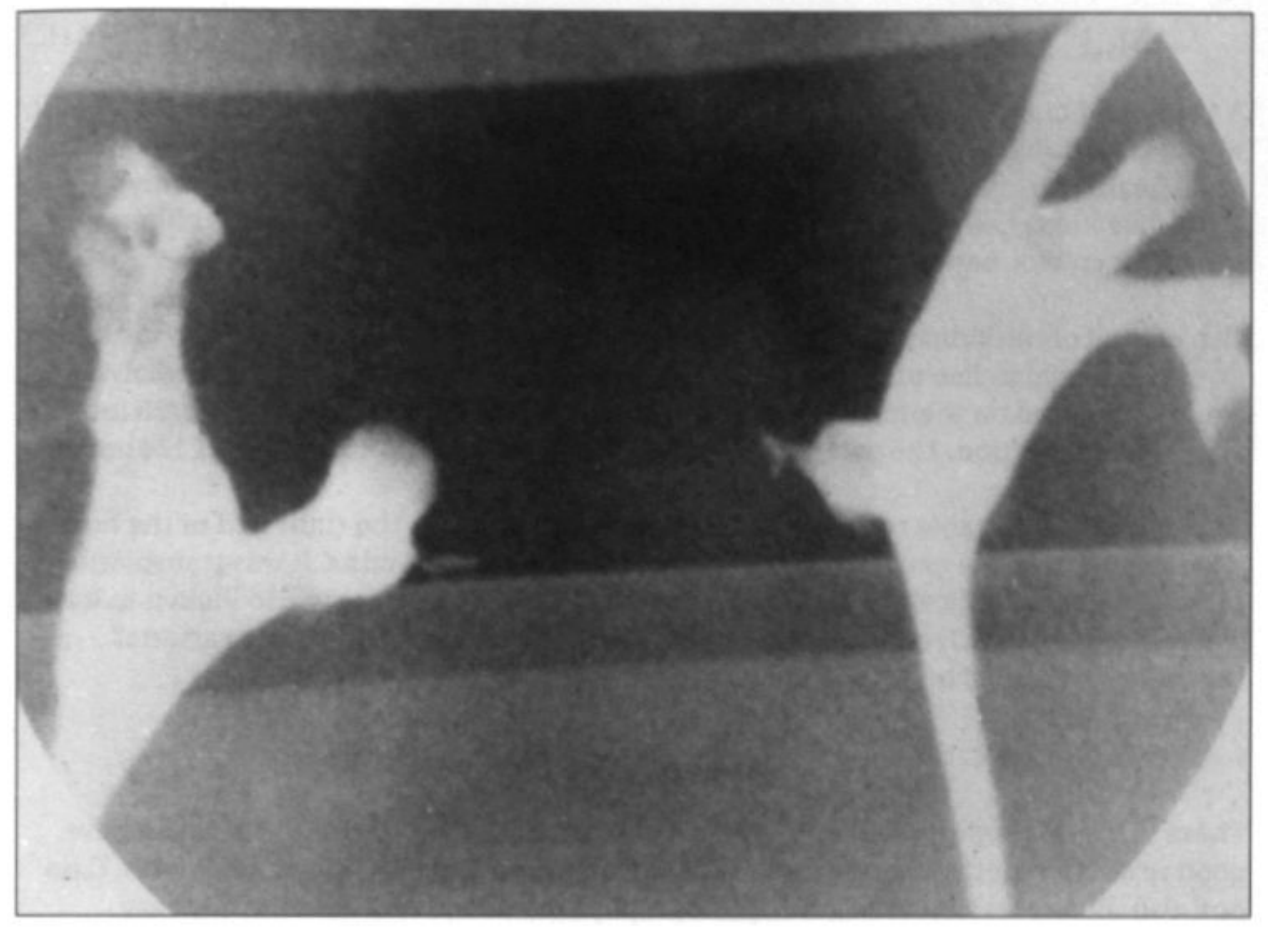

FIGURE 8.1:

Retrograde pyelography of the horseshoe kidney, revealing two separate urinary collecting systems.

CASE 2

A 15 year old male suffered brain death after a fatal fall of a horse. He had no known history of urinary tract disease (Blood urea nitrogen $1.2 \mathrm{mmol} / \mathrm{l}$; serum creatinine $41 \mu \mathrm{mol} / \mathrm{l}$ ). Permission for organ donation was obtained. A horseshoe kidney with 6 arteries and 4 veins was explanted and divided after careful inspection.

Following a cold ischaemic time of 39 hours, the left half of the horseshoe kidney was transplanted into a 26 year old man who suffered of Alports disease. Renal function was immediate and 12 years after transplantation the kidney function is still good, with a serum creatinine of 300 to $400 \mu \mathrm{mol} / \mathrm{l}$.

The right half of the horseshoe kidney was transplanted into a 60 year old man with end stage renal failure of an unknown origin. The cold ischaemic time was 44 hours. The renal function was immediate. Three years after transplantation the patient died of a pulmonary carcinoma, with a good renal function and a serum creatinine of $200 \mu \mathrm{mol} / \mathrm{l}$. 


\section{CASE 3}

A 14 year old male with no history of urinary tract disease (Blood urea nitrogen $6.2 \mathrm{mmol} / \mathrm{l}$; serum creatinine $98 \mu \mathrm{mol} / \mathrm{l})$, sustained cerebral trauma in a traffic accident, followed by brain death. Permission for organ donation was obtained and during laparotomy a horseshoe kidney with $\mathbf{5}$ arteries and $\mathbf{5}$ veins was discovered. The horseshoe kidney was split after en bloc nephrectomy.

The left half of the kidney was transplanted into a 45 year old woman with polycystic kidney disease. The cold ischaemic time was 28 hours. Function was delayed and haemodialysis could be aborted on the 16 th day after transplantation. The last follow-up was 26 months after transplantation. The patient was doing well, with a serum creatinine of $124 \mu \mathrm{mol} / 1$.

Due to lack of a suitable recipient in the Eurotransplant area the right half of the horseshoe kidney was transported to a transplant center in Saudi-Arabia. It was transplanted into a 38 year old male diabetic with end stage renal disease. He was also known to have generalized atherosclerosis. The transplantation resulted in failure due to arterial thrombosis within 8 hours postoperatively.

\section{CONCLUSION}

These three case reports show that the transplantation of horseshoe kidneys can have good results when the technical pitfalls are recognised and adequately dealt with. Case one also illustrates that retrograde pyelography is an adequate and relatively easy method to reveal the anatomy of the urinary collecting systems.

\section{Reference}

1. Daemen JHC, Oomen APA. Janssen MA, van de Schoot L, van Kreel BK. Heineman E, Kootstra G. Glutathione-S. transferase as predictor of functional outcome in transplantation of machinepreserved non-heart-beating donor kidneys. Transplantation 1997; 63: 89-93. 
CHAPTER 9

\section{THE MANAGEMENT OF AORTIC ANEURYSMS IN THE PRESENCE OF A HORSESHOE KIDNEY}

O.B. Stroosma, G. Kootstra, G.W.H. Schurink

Published in:

The British Journal of Surgery 2001; 88: 500-9. 


\section{INTRODUCTION}

The commonest anatomical variation of the kidney is the horseshoe kidney. It represents a fusion anomaly, mainly at the lower poles, that occurs between the fourth and sixth week of gestation. The isthmus connecting the lower poles may be a fibrous band or may contain functional parenchyma'. Horseshoe kidneys show a great variation in origin, number and size of the renal arteries and veins; only $30 \%$ of all horseshoe kidneys have a single renal artery to each side ${ }^{2}$. The combination of such a renal anomaly with an aortic aneurysm presents a diagnostic and therapeutic challenge to the vascular surgeon. This article describes the published experience of this situation and comments on the consequences of the variations that might be encountered with this interesting dual pathology.

\section{MATERIALS AND METHODS}

A Medline search carried out using the keywords horseshoe, kidney and aneurysm revealed 78 publications. The references from these publications revealed a further 11 publications. A total of 89 publications ${ }^{391}$ describing one or more cases of an aortic aneurysm in combination with a horseshoe kidney were therefore considered. No limit was set to the year or language of publication. One overlapping report ${ }^{21}$ was found and excluded, leaving 88 publications ${ }^{3 * 0}$ to be reviewed. The authors' own experience, consisting of two cases, was also included.

All publications were studied for the following variables: year of publication, country and number of cases of aortic aneurysm with a horseshoe kidney. The following variables were recorded for the individual cases: sex and age of the patient, complaints related to the horseshoe kidney, cardiovascular risk factors (hypertension, diabetes mellitus, nicotine abuse and previous cardiovascular diseases), diagnostic procedures used, diameter and extend of the aneurysm, presentation (asymptomatic or ruptured), time of diagnosis of the horseshoe kidney (preoperative or peroperative), and the general and vascular anatomy of the horseshoe kidney. Data were also collected about the operative approach, the level of cross-clamping of the aorta, separation of the isthmus, the number of renal arteries arising from the aneurysm and how these were handled during operation. Follow-up time was recorded, as well as the postoperative serum creatinine level, morbidity and mortality. The cases were analysed according to clinical presentation (asymptomatic or ruptured). The influence of the time of diagnosis (preoperative versus peroperative) of the horseshoe kidney was analysed for both groups. 


\section{RESULTS}

\section{PATIENTS}

A total of 176 cases were reported in the 88 articles published from 16 countries between 1956 until $1999^{20}$ (including the authors' own two cases). One case report described the combination of an aortic aneurysm with a cake kidney" , a form of fusion of the kidneys in which both the upper poles and the lower poles are fused; this case was included in the study. Information on the follow-up time and the postoperative serum creatinine levels was described for less then $15 \%$ of the patients, so these variables were excluded from the analysis. There were 148 men and 11 women; the sex was not reported for the remaining 17 patients. Mean age was 65 (range 31-91) years. Seventy $(40 \%)$ patients were reported to have cardiovascular risk factors. Of these, 38 had hypertension, 10 diabetes mellitus, 28 nicotine abuse and 35 had a previous cardiovascular disease. Seven (4\%) patients had complaints related to the horseshoe kidney: Two were caused by hydronephrosis, four by kidney stones and one patient had recurrent infections in combination with kidney stones. Almost all $(172 ; 98 \%)$ of the horseshoe kidneys had a parenchymatous isthmus: a fibrous isthmus was recorded in three $(2 \%)$ and in one the anatomy was not reported. In $134(76 \%)$ patients the aneurysm was asymptomatic. Acute presentation with a ruptured aneurysm occurred in $42(24 \%)$ cases.

\section{ASYMPTOMATIC ANEURYSMS}

In this group of 134 aneurysms aneurysm was diagnosed by abdominal radiography in $11(8 \%)$ cases, aortography in 41 $(31 \%)$ cases and ultrasonography in $16(12 \%)$ cases. Computed tomography (CT) was used as a diagnostic procedure in $51(38 \%)$ patients. In two instances the aneurysm was an operative finding and in one patient diagnostic laparoscopy, performed on the suspicion of appendicitis, revealed the abdominal aneurysm and a horseshoe kidney. In 12 (9\%) patients the modality used to diagnose the aneurysm was not described. There were 77 $(58 \%)$ aneurysms of the abdominal aorta and $53(40 \%)$ aortoiliac aneurysms; in four $(3 \%)$ instances the extent of the aneurysm was not reported. Mean diameter was 68 (range 30110) $\mathrm{mm}$ but in 57 cases the diameter was not recorded. Most horseshoe kidneys (108; $81 \%$ ) were diagnosed before operation; $26(19 \%)$ were diagnosed during surgery. In these 26 cases the aneurysm had been diagnosed by plain abdominal radiography in three, by aortography in seven and by ultrasonography in nine cases. In two cases CT had been used and the horseshoe kidney had been missed. The diagnostic procedure was not described for the remaining five patients.

Table 9.1 shows the vascular anatomy and the number of renal arteries occluded and reanastomosed for the horseshoe kidneys diagnosed before and during operation in both the asymptomatic and ruptured groups. The mean number of renal arteries in the asymptomatic group was 3.1 (range 2-7) and 3.9 (range 2-16) for the horseshoe kidneys diagnosed before and during operation respectively. 


\begin{tabular}{|c|c|c|c|c|}
\hline & \multicolumn{2}{|c|}{$\begin{array}{l}\text { Asymptomatic aneurysms } \\
\text { Horseshoe kidney diagnosed }\end{array}$} & \multicolumn{2}{|c|}{$\begin{array}{l}\text { Ruptured aneurysms } \\
\text { Horseshoe kidney diagnosed }\end{array}$} \\
\hline & Before operation & At operation & Before operation & At operation \\
\hline Total number of cases & 108 & 26 & 23 & 19 \\
\hline $\begin{array}{l}\text { Cases with renal arteries } \\
\text { originating from aneurysm }\end{array}$ & 42 & 12 & 10 & 9 \\
\hline \multicolumn{5}{|l|}{ Renal arteries: } \\
\hline Total & 325 & 102 & 78 & 53 \\
\hline From aneurysm & 77 & $>30$ & 18 & 13 \\
\hline Occluded & $34(50 \%)$ & $13(54 \%)$ & $16(89 \%)$ & $7(54 \%)$ \\
\hline Re-anastomosed & $34(50 \%)$ & $11(46 \%)$ & $2(11 \%)$ & $6(46 \%)$ \\
\hline
\end{tabular}

\section{TABLE 9.1:}

Renal arteries: anatomy and management.

Table 9.2 shows the same variables for the six different operative approaches described:

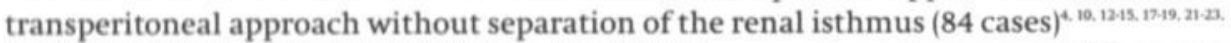

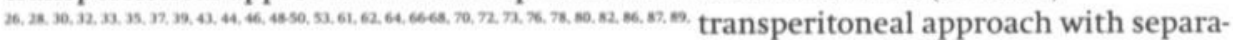

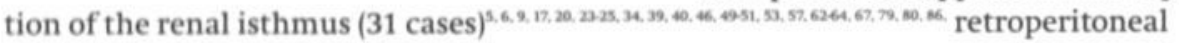

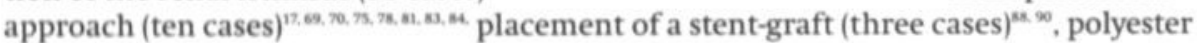

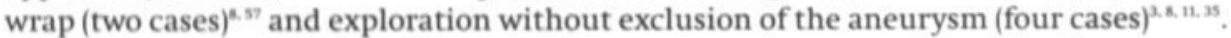
Aortic cross-clamping above the level of the renal arteries was performed in five cases $(4 \%)$. In $11(8 \%)$ the clamp was applied below the renal arteries and in four $(3 \%)$ it was positioned between the renal arteries. The level of cross-clamping of the aorta was not described in $114(85 \%)$ cases. Complications were reported in nine $(7 \%)$ patients. Two developed ischaemia of one leg, treated by embolectomy. Two postoperative bleeding requiring re-exploration; one of these patients had developed a retroperitoneal haematoma caused by bleeding from the cut edges of a separated renal isthmus. Five (4\%) patients developed renal insufficiency, of whom three needed temporary haemodialysis. Division of renal arteries was described in two of the five cases complicated by renal insufficiency: in none of these cases was the level of cross-clamping of the aorta mentioned. Of the five patients who suffered from renal insufficiency, four had had a transperitoneal approach to the aneurysm with separation of the renal isthmus and the remaining patient had had a transperitoneal approach without separation of the renal isthmus. Five (4\%) of the patients with an asymptomatic aneurysm died, two from haemorrhagic shock, two from multiorgan failure and one from renal insufficiency. 


\begin{tabular}{|c|c|c|c|c|c|c|c|}
\hline & TP/nos & TPS & RP & SG & Wrap & Neg Expl & Total \\
\hline Total number of cases & 84 & 31 & 10 & 3 & 2 & 4 & 134 \\
\hline $\begin{array}{l}\text { Cases with renal arteries } \\
\text { originating from aneurysn }\end{array}$ & 28 & 18 & 2 & 2 & 1 & 3 & 54 \\
\hline \multicolumn{8}{|l|}{ Renal arteries: } \\
\hline Total & 252 & 99 & 41 & 12 & 3 & 20 & 427 \\
\hline From aneurysm & 47 & 35 & 7 & 3 & 2 & $>13$ & $>107$ \\
\hline Occluded & $17(36 \%)$ & $20(57 \%)$ & $7(100 \%)$ & $3(100 \%)$ & $o(0 \%)$ & na. & 47 \\
\hline Re-anastomosed & $30(64 \times)$ & $15(43 \%)$ & o & na. & na. & na. & 45 \\
\hline
\end{tabular}

TABLE 9.2:

Renal arteries: operative intervention and management in the elective setting. (TP/no S: Transperitoneal approach without separation of the renal isthmus; TP/S: Transperitoneal approach with separation of the renal isthmus; RP: Retroperitoneal approach; SG: Stent-graft; Neg expl: Exploration without exclusion of the aneurysm; n.a.: not applicable.)

\section{RUPTURED ANEURYSMS}

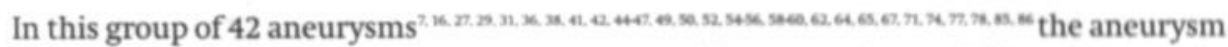
was diagnosed by physical examination in $18(43 \%)$ instances. In one $(2 \%)$ patient a plain abdominal radiograph was the diagnostic procedure used. Eleven $(26 \%)$ aneurysms were diagnosed by aortography, six $(14 \%)$ by ultrasonography and five $(12 \%)$ by CT. In one $(2 \%)$ case the diagnostic procedure used was not described. A thoracoabdominal aneurysm was diagnosed in one $(2 \%)$ patient. In $20(48 \%)$ patients the aneurysm was limited to the abdominal aorta and in $21(50 \%)$ there was iliac involvement. The diameter of the aortic aneurysms varied from $30 \mathrm{~mm}$ to 250 (mean 86 ) $\mathrm{mm}$; the diameter was not described in 26 cases. The horseshoe kidney was diagnosed before operation in $23(55 \%)$ patients and during operation in $19(45 \%)$ patients (Table 9.1). Of the 19 patients in whom the horseshoe kidney was diagnosed during operation, the aneurysm had been diagnosed by physical examination in 15 , by abdominal radiography in one and by aortography in two patients. In one case the method of diagnosis of the aneurysm was not described. 
The mean number of renal arteries was 3.3 (range 2-7) and 2.7 (range 1-7) for horseshoe kidneys diagnosed before and after operation respectively. Table 9.3 shows the vascular anatomy and the number of renal arteries occluded and re-anastomosed for the three operative approaches described in this group: transperitoneal approach without separa-

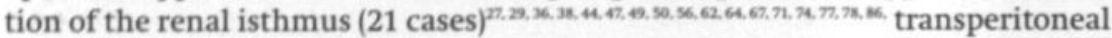

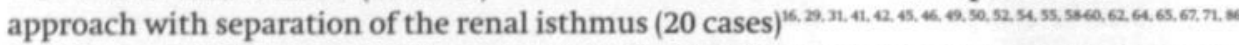
and placement of a stent-graft (one case) ${ }^{\mathrm{n}}$. In five (12\%) cases the aorta was cross-clamped above the level of the renal arteries, in seven (17\%) the aortic clamp was applied below the level of the renal arteries and in the remaining 30 (71\%) cases the level of cross-clamping was not described. Eight (19\%) patients developed complications. Ischemia of one leg, requiring embolectomy, was noted in one patient. Development of renal insufficiency was described in seven (17\%) patients, four of whom were treated with temporary haemodialysis. One of the seven cases complicated by renal insufficiency had had suprarenal aortic cross-clamping; the level of cross-clamping was not reported for the other six. Division of renal arteries originating from the aneurysm was not described in any of the seven cases complicated by renal insufficiency. Of these seven cases, renal insufficiency occurred after a transperitoneal approach with separation of the renal isthmus in three $(43 \%)$. Six $(14 \%)$ patients in this group died, three from haemorrhagic shock, one from multiorgan failure, one from adult respiratory distress syndrome and one from myocardial infarction.

\begin{tabular}{|c|c|c|c|c|c|c|c|}
\hline & TP/nos & TP/S & RP & SG & Wrap & Neg Expl & Total \\
\hline Total number of cases & 21 & 20 & - & 1 & $\cdot$ & - & 42 \\
\hline $\begin{array}{l}\text { Cases with renal arteries } \\
\text { originating from aneurysm }\end{array}$ & 6 & 12 & - & 1 & - & - & 19 \\
\hline \multicolumn{8}{|l|}{ Renal arteries: } \\
\hline Total & 57 & 70 & - & 4 & - & $\cdot$ & 131 \\
\hline From aneurysm & 11 & 19 & * & 1 & - & $\cdot$ & 31 \\
\hline Occluded & $9(82 \%)$ & $13(68 \%)$ & - & $1(100 \%)$ & - & - & 23 \\
\hline Reanastomosed & $2(18 \%)$ & $6(32 \%)$ & - & na. & - & - & 8 \\
\hline
\end{tabular}

TABLE 9.3:

Renal arteries: operative intervention and management in the emergency (ruptured aneurysm) setting. (TP/no S: Transperitoneal approach without separation of the renal isthmus; TP/S: Transperitoneal approach with separation of the renal isthmus; RP: Retroperitoneal approach;SG: Stent-graft; Neg expl: Exploration without exclusion of the aneurysm; n.a.: not applicable.) 


\section{Discussion}

The first documentation of a horseshoe kidney was by Berenger da Carpi in $1522^{2}$, but the first detailed description of the anomaly was written in 1665 by Botallus" ${ }^{*}$. The combination of a horseshoe kidney and an abdominal aortic aneurysm was described for the first time by Julian in $1956^{3}$, and in 1957 Phelan et al. ${ }^{4}$ were the first to exclude an aneurysm in the presence of a horseshoe kidney. Since that time a number of operative approaches have been described to enable the aneurysm to be repaired with preservation of renal function. At first exclusion of the aneurysm was considered to be too difficult because of the complex vascular anatomy (years of publication: 1956, 1964, 1968 and $1975)^{2.11 .13}$; two reports describe the aneurysm being wrapped with polyester, a therapy now obsolete (years of publication: 1964 and 1984). ${ }^{\mathrm{s}}$. In the early years when aneurysms were excluded, the renal isthmus overlying the aorta was divided (years of publication

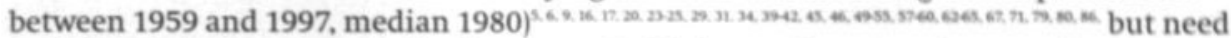
to divide the isthmus gradually disappeared with increasing operative experience (years

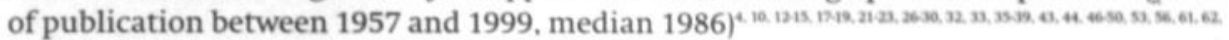
4. cated by some authors (years of publication between 1969 and 1997, median 1993) ${ }^{12.62}$.r. 3. 78.81 .80 .44 and, finally, the endoluminal placement of a stent-graft was introduced as a method of treating selected cases of aneurysms plus horseshoe kidney (years of publication 1997,1998 and 1999$)^{\mathrm{ses}, \mathrm{sc} . \mathrm{x}}$

The incidence of horseshoe kidney is one in 600 to 800 ; it is twice as common in men as in women'. Because men have a higher incidence of aortic aneurysm" ${ }^{\circ}$, the combination of a horseshoe kidney and aneurysm is encountered more frequently in men, as the present study has shown. Nevertheless the male : female ratio in the present work of about 13:1 is higher than might be expected. Numerous cardiovascular anomalies have been reported to accompany a horseshoe kidney ${ }^{39}$, and so those with such a lesion might be at higher risk of developing an aortic aneurysm than the general population. Two thirds of the horseshoe kidneys present as complications, such as recurrent urinary tract infections. renal calculi and hydronephrosis'. In this review, only seven $(4 \%)$ patients were reported to have one of these complications. Presumably more patients must have had such complaints, but they were not described in the publications studied. The same holds for cardiovascular risk factors which were only reported in $70(40 \%)$ cases. 


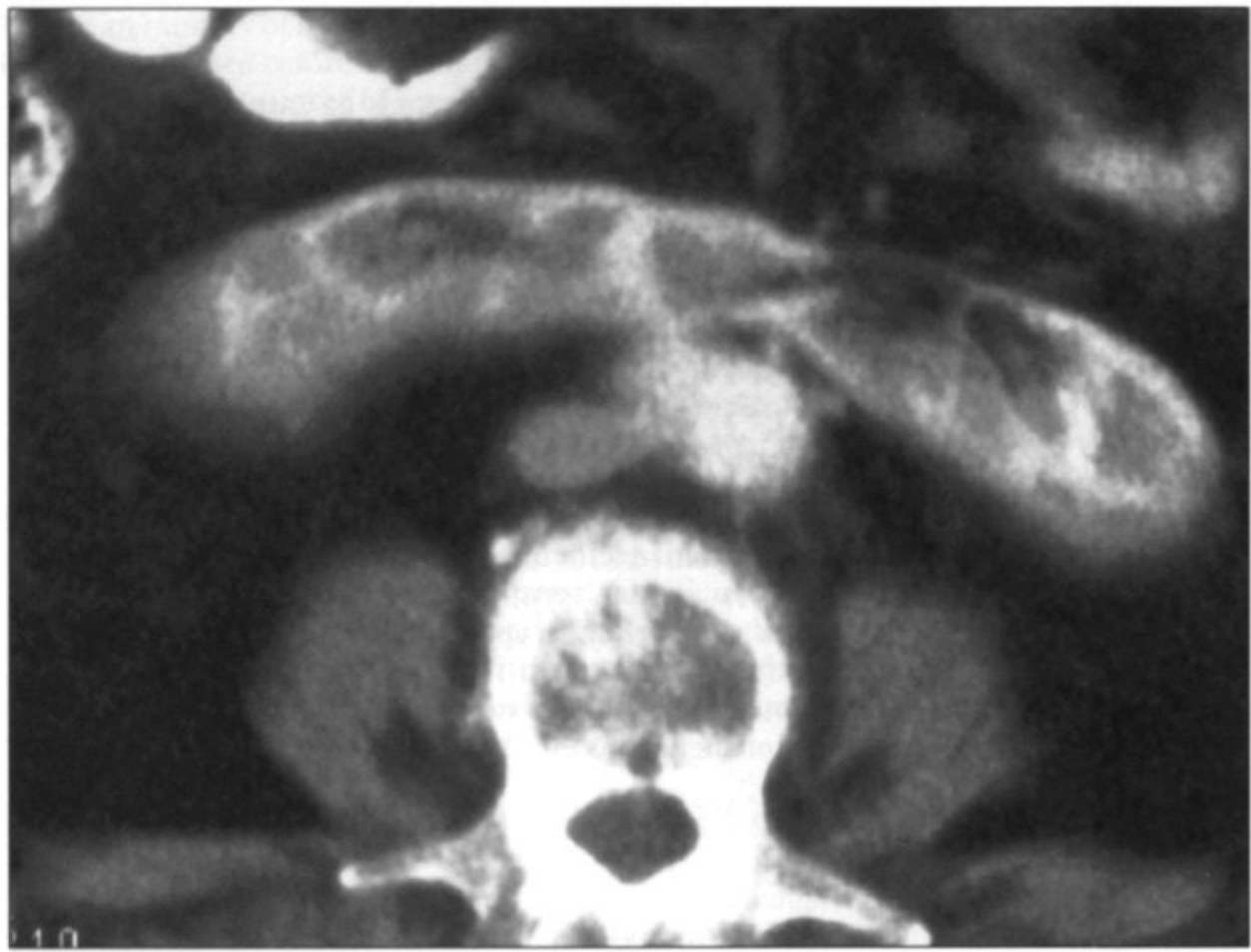

Figure 9.1:

Computed tomography showing the parenchymatous isthmus of a horseshoe kidney overlying the non-dialated part of the aorta just proximal to an aortic aneurysm.

Computed tomography (CT) provides the best chance of diagnosing both the abdominal aneurysm and the horseshoe kidney (figure 9.1), followed by aortography (figure 9.2). The horseshoe kidney was missed on CT in only two cases and in $17 \%$ of the aortographies. Because CT is now the initial diagnostic modality of choice for asymptomatic aortic aneurysms", the presence of a horseshoe kidney will often be known before operation. As would be expected, the chance of an unanticipated horseshoe kidney is far greater in those with a ruptured aneurysm than in the elective setting. In the group with ruptured aneurysm, the renal anomaly was diagnosed during operation in 19 of 42 patients $(45 \%)$; in the asymptomatic aneurysm group the proportion was $19 \%$. This difference is caused by the lack of time for diagnostic tests in the emergency setting. For asymptomatic aneurysm, an equal number of renal arteries arising from the aneurysm was occluded $(51 \%)$ or re-anastomosed $(49 \%)$ on the graft, independent of the time of diagnosis of the horseshoe kidney. For the ruptured aneurysm, the majority of the renal arteries arising from the aneurysm were occluded $(74 \%)$. There does not seem to be an advantage of a preoperatively diagnosed horseshoe kidney in this group, as the proportion of divided renal arteries was highest in the preoperatively diagnosed group ( $89 \%$ compared with $54 \%$ in the peroperatively diagnosed horseshoe kidneys). However, it should be noted that most of the renal arteries that were divided were described as being small. 
In the majority of patients, the aneurysm was excluded through a transperitoneal approach, with or without separation of the renal isthmus. A transperitoneal approach without division of the renal isthmus (figure 9.3) was reported in $63 \%$ of the asymptomatic group and in $50 \%$ of the ruptured group. A transperitoneal approach with separation of the renal isthmus was performed in $23 \%$ of the asymptomatic group and in $48 \%$ of the ruptured group. In the asymptomatic patients more renal arteries arising from the aneurysm were divided when the isthmus was split than when the isthmus was left intact. This result was to be expected because the arteries to the renal isthmus have a higher chance of being divided when the horseshoe kidney is split. For ruptured aneurysms, the need for rapid vascular control probably lowers the threshold for division of the renal arteries and isthmus. This may well be the reason for the high proportion of divided renal arteries and isthmuses in the emergency setting.

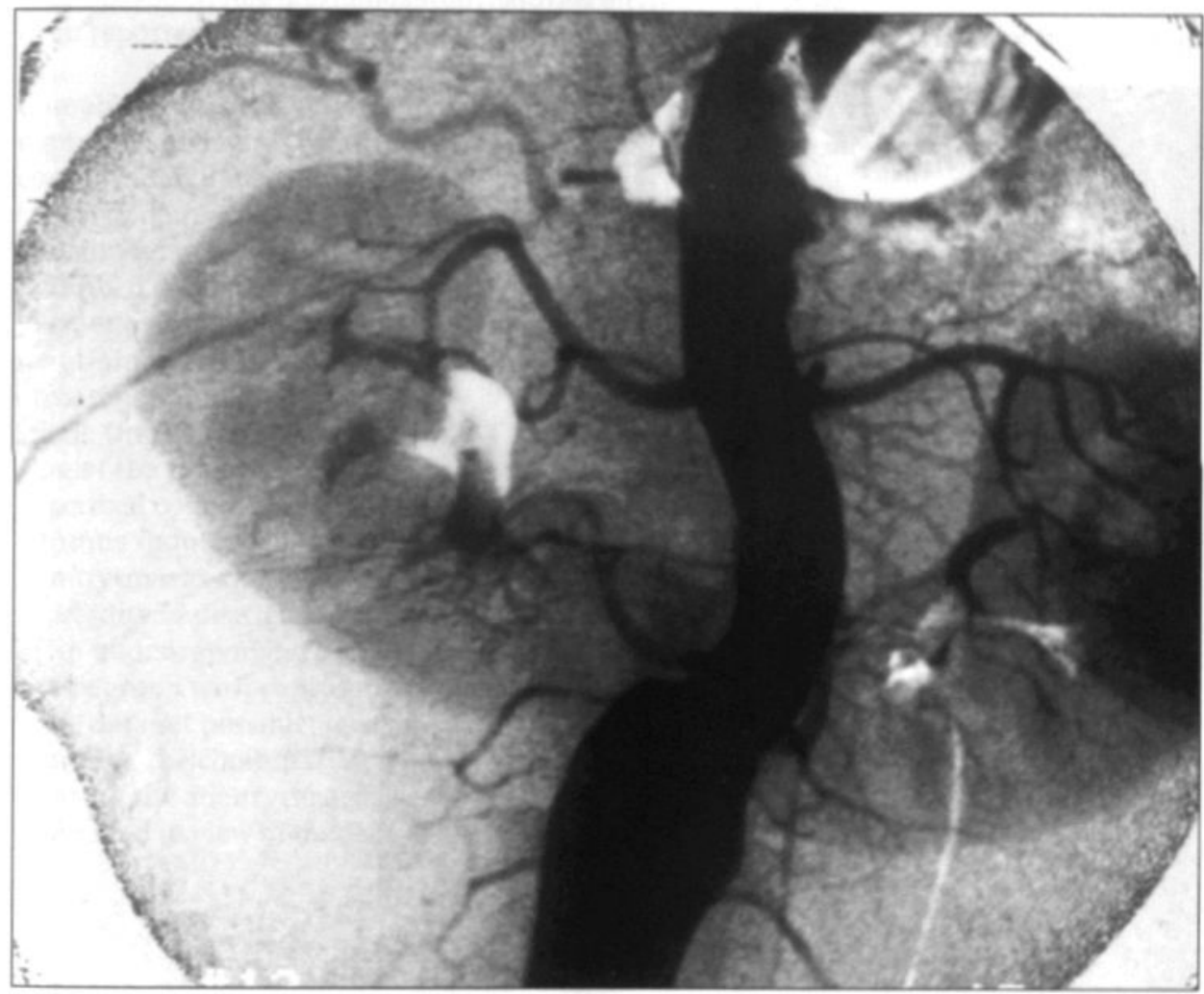

FIGURE 9.2:

Aortography of the patient in figure 9.1 showing an aortic aneurysm and a horseshoe kidney. There are two renal arteries on the left side and two on the right side; all four renal arteries originate from the aorta above the level of the aneurysm. 
Although transperitoneal exposure for aortic reconstruction has dominated over the past four decades ${ }^{n}$, some authors advocate a retroperitoneal approach for aortic surgery $^{3.100,100}$. This has several advantages over the transperitoneal approach. It avoids interference with the renal isthmus, the urethers and most renal arteries and veins. However the approach to the contralateral iliac artery is more difficult and the technique has been used exclusively in the elective setting. The present review shows that, although said as being relatively easy, the renal arteries arising from the aneurysm were all divided and no anastomoses to the aortic prostheses were made using the retroperitoneal approach. However, there were only ten cases, a number that is too small to permit any definite conclusions. The authors believe that the theory behind using a retroperitoneal approach for the exclusion of an asymptomatic aortic aneurysms in combination with a horseshoe kidney is strong. Despite the fact that in all published series all renal arteries arising from the aneurysm were divided, the retroperitoneal method can be advocated in the elective setting.

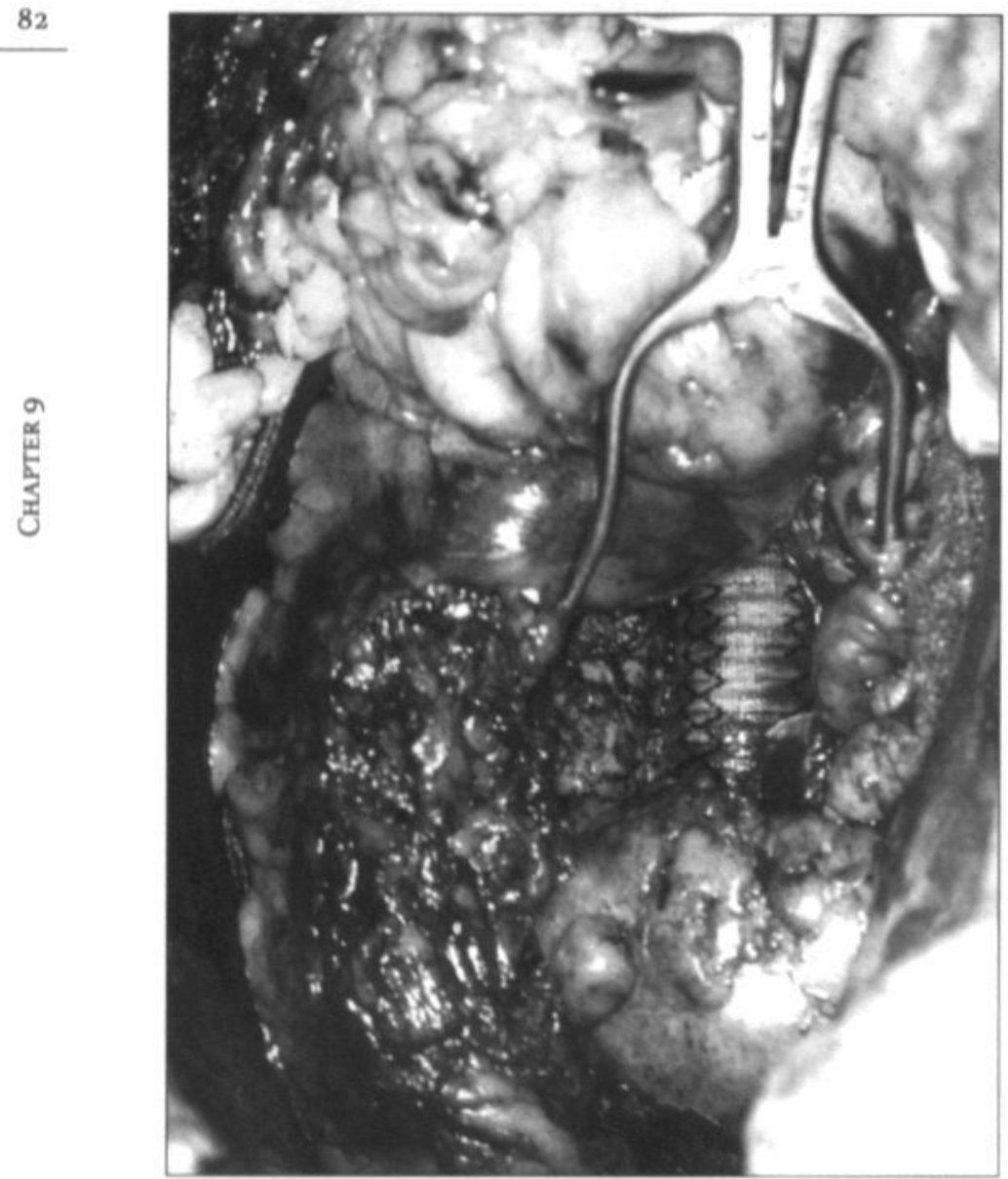

Figure 9.3:

Peroperative view of the patient in figures 9.1 and 9.2. A horseshoe kidney lies inferior to a tube graft excluding an aortic aneurysm. 
Theoretically the easiest method of avoiding the technical difficulties associated with the combination of an aortic aneurysm and a horseshoe kidney is to treat the aneurysm endoluminally with a stent-graft ${ }^{\text {ser }} 102.00$. The disadvantage is that, for obvious reasons. aberant renal arteries cannot be anastomosed to the prosthesis and will be covered by the stent-graft. If these vessels originate from the aneurysm neck, it would be possible to place a bare stent across their origins ${ }^{\mathrm{kn}}$ but as is shown in tables 9.2 and 9.3 , all renal arteries arising from the aneurysm were obliterated in both the asymptomatic and the ruptured cases using this method. A limitation of the technique is that the morphology of the aneurysm must be suitable for endovascular exclusion. This, and the presence of many or large renal arteries originating from the aneurysm, creates a contraindication to stent-graft placement in most cases. In the authors' opinion, the endovascular exclusion of an asymptomatic aneurysm can be advocated when morphologically feasible, but it must be accepted that support for this statement is scant as only four cases have so far been reported.

Complications were much less common in the asymptomatic patients than in those with ruptured aneurysms ( $7 \%$ and $19 \%$ respectively). Renal insufficiency was the most common complication in both groups $(4 \%$ and $17 \%$ respectively). Division of the renal isthmus seems to increase the chance of developing renal insufficiency in both the elective (13\%) and emergency (15\%) setting. Unfortunately, the level of aortic cross-clamping was described very infrequently and so no conclusion about suprarenal aortic cross-clamping in relation to renal insufficiency can be drawn. Surprisingly, the number of renal arteries originating from the aneurysm that are divided does not seem to influence postoperative renal function. The most probable explanation is that the divided arteries were small. One patient with an asymptomatic aneurysm suffered a haemorrhage after division of the renal isthmus. Together with urinary fistula formation, this is a frequently described complication of splitting the isthmus ${ }^{104}$. These findings suggest that the renal isthmus should ideally be left intact to reduce morbidity. In patients in whom the aneurysm was approached retroperitoneally or in whom a stent-graft was placed, no morbidity or death was reported. The authors recognize that this study is biased because of an under-reporting of failed cases. This is illustrated by the low mortality rate of $14 \%$ in the group with ruptured aneurysm. Nevertheless, this review presents the most complete data set possible; it can be used to suggest the optimal treatment and the pitfalls in handling the combination of an aortic aneurysm and a horseshoe kidney. Certainly, not treating the aneurysm, as was described in some early $\operatorname{cases}^{3.4 .11 .35,57}$ can no longer be advocated in view of modern therapeutic possibilities. 


\section{RECOMMENDATIONS}

A guideline for the diagnosis and treatment of aortic aneurysms in combination with a horseshoe kidney is outlined in figure 9.4. Adequate preoperative diagnosis of the horseshoe kidney and its vascular anatomy is important in choosing the best surgical approach in each individual patient, even though it does not seem to influence the peroperative handling of aberrant renal arteries. The unanticipated combination of an aneurysm and a horseshoe kidney can be avoided by using helical CT which is, in any event, the diagnostic modality of choice for general planning of surgery for aortic aneurysm. If helical CT is not available, the combination of a conventional CT and an aortography is advised. When a patient with a ruptured aneurysm is in shock there is no time for extensive diagnostics. In such cases the aneurysm is diagnosed by physical examination and ultrasonography, and the presence of a horseshoe kidney might be missed. However, this has no significance in the choice of surgical approach. In the emergency setting the authors advocate a transperitoneal approach to gain maximal overview and rapid vascular control. Clamping of the aorta can be done at the usual site. The risk of damage to the horseshoe kidney and it's vasculature is minimal because of the distal position of the organ and the fact that most abberant renal arteries originate distal to the horseshoe kidney itself. The renal isthmus should be spared if possible. In patients with an asymptomatic aneurysm, the horseshoe kidney should normally be discovered before operation. Adequate knowledge of the vascular anatomy is essential to determine the approach of choice under such circumstances. When the aortic morphology is suitable and no dominant renal arteries originate from the aneurysm, the placement of a stent-graft should be considered. If dominant renal arteries arise from the aneurysm, the retroperitoneal approach seems to be a valuable method which avoids the overlying isthmus. As many accessory renal arteries as possible should be re-anastomosed to the prosthesis. 


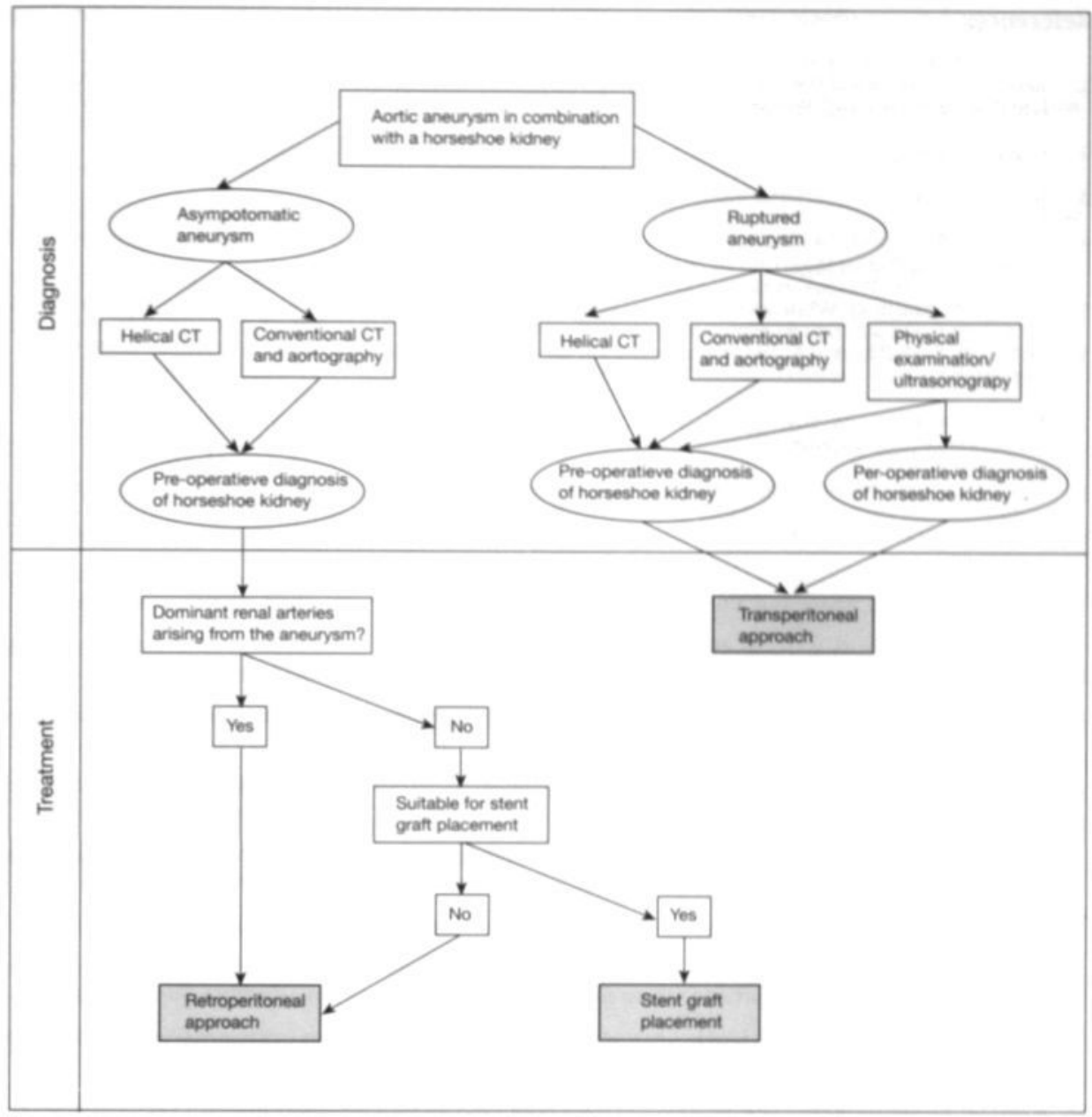

FIGURE 9.4:

Flow diagram showing the diagnosis and treatment of aortic aneurysm in combination with a horseshoe kidney. 


\section{References}

1. Bauer SB. Anomalies of the kidney and ureteropelvic junction. In: Walsh PC, Retik AB, Vaughan ED Jr. Wein AJ. eds. Campbell's urology. Philadelphia: WB Saunders, 1998: 1708-57.

2. Graves FT. The arterial anatomy of the congenitally abnormal kidney. Br J Surg 1969: 56: 533-41.

3. Julian OC. Diagnosis in arterial disease. Surg Clin North Am 1956: 36: 177-91.

4. Phelan JT, Bernatz PE, DeWeerd JH. Abdominal aortic aneurysm associated with a horseshoe kidney: Report of a case. Proc Staff Meet Mayo Clin 1957; 32: 77-81.

5. Szilagyi DE, Smith RF, Whitcomb JG. The kidneys in surgery of the abdominal aorta. Arch Surg 1959; 79: $252-69$.

6. Wilder JR, Koch JM, Stein A. Abdominal aortic aneurysms in association with horseshoe kidney. JAMA 1963; 183: 1038-41.

7. Mannick JA, Brooks JW, Bosher jr LH. Hume DM. Ruptured aneurysms of the abdominal aorta. A reappraisal. N Engl J Med 1964: 271: 915-20.

8. Falor WH, Rufflo RA. Horseshoe kidney complicated by abdominal aortic aneurysm. J Urol 1964: $91: 131-4$.

9. Lynn RB, Bruce AW. An abdominal aortic aneurysm associated with a horseshoe kidney. Canad Med Ass J 1965: 93: 979-80.

10. Minken SL. Rob CG. Abdominal aneurysm and horseshoe kidney: A case report and collective review. Surgery 1967: 61: 719-22.

11. Cox WL, Machado G. Abdominal aortic aneurysm with a horseshoe kidney. Angiology 1968: 19:351-3.

12. Love JW, Calhoon HW, Ross FA. An abdominal aortic aneurysm associated with a horseshoe kidney. Am Surg 1968: 34: 354.7 .

13. Killen DA, Scott jr HW. Rhamy RK. Aneurysm and arterial occlusive disease of the abdominal aorta and its major branches associated with horseshoe kidney. Am J Surg 1968: 116:920-4.

14. Albonico C, Dileo L. Mattiussi R. Contributo clinico allo studio sugli aneurismi dell'aorta addominale associati a rene a ferro di cavallo. Minerva Chir 1968: 23: 1-9.

15. Trabattoni P. Miele F, Losapio GM. Aneurisma dell'aorta addominale associato a rene a ferro di cavallo. Min Cardioang 1969; 17: 785-90.

16. Sigler L. Geary JE. Abdominal aortic aneurysm and unexpected horseshoe kidney. J Cardiovas Surg 1969: 10:320-3.

17. Scott jr R, DeBakey ME, Mani P. Surgical correction of abdominal aortic disease in 8 patients with horseshoe kidney. J Urol 1969: 102: 21-6.

18. Cohn LH. Stoney RJ. Wylie EJ. Abdominal aortic aneurysm and horseshoe kidney. Ann Surg 1969: 170: $870-4$.

19. Courbier MR. Prothèse aortique et rein en fer á cheval. Mem Acad Chir 1969: $95: 795-800$

20. Hoofer WD. Abdominal aortic aneurysm associated with horseshoe kidney. J Kansas Med Soc 1970: $71: 457-9$.

21. Marable SA. Thomford NR. Abdominal aortic aneurysm associated with horseshoe kidney. Angiology 1970; $21: 1249$.

22. Press $C$. An abdominal aortic aneurysm associated with a horseshoe kidney. Vasc Surg 1970: 4: 71 -5.

23. Lacombe M. Vaysse J. Andreassian B. Desmonts JM. Anévrisme de l'aorte abdominale et rein en fer a cheval. Etude d'ensemble a propos de deux cas. Ann Chir Thor Car 1970; 9: 207-15.

24. Coquillaud JP. Roullet JC. Bersay C. Roger W. A propos d'un nouveau cas d'anévrysme de l'aorte abdominale associé a un rein en fer a cheval. Chirungie 1971; 97: 717-21.

25. Natali J, Méry JP, Maraval M. Anévrysme de l'aorte abdominale et rein en fer à cheval. Chirurgie 1971:97:41-5.

26. Davis jr JT. Hardin W]. Hardy JD, Neely WA. Abdominal aneurysm and horseshoe kidney. South Med J 1971:64: $75-7$.

27. Hardy JD. Timmis HH. Abdominal aortic aneurysms: Special problems. Ann Surg 1971: 173: $945-65$

28. Kilgore jr TL_ Johnston jr JH. Aneurysms of the abdominal aorta with special problems. Am Surg 1971: $37: 238-44$.

29. Cayten CG. Davis AV. Berkowitz HD, Roberts B. Ruptured abdominal aortic aneurysms in the presence of horseshoe kidney. Surg Gynecol Obstet 1972; 135:945-9.

30. Frawley JE, Dickson GH. Jamieson CW. Eastcott HHG. Abdominal aortic aneurysm and horseshoe kidney. Br J Surg 1972:59:513-7.

31. Vereecken L. Derom F, DeRoose J. A case of ruptured aortic aneurysm associated with horseshoe kidney. Acta Chir Belg 1973: 72: 46-9. 
32. Evans WE. Moser BM. Aortic aneurysm and horseshoe kidney. Vasc Surg 1973: 7: 56-9.

33. Symes JM. Eadie DG. Horseshoe kidney and abdominal aortic aneurysm. Br J Surg 1973:60: 243-5.

34. Fuller CH. Spence HM. Willbanks OL. Management of horseshoe kidney and pelvic kidney during aortic operation. South Med J 1974: 67: 492-4.

35. Bietz DS, Merendino KA. Abdominal aneurysm and horseshoe kidney: a review. Ann Surg 1975: 181: 333-41.

36. Van Gelderen PW. Brands LC. Ruptured aneurysm of the abdominal aorta in the presence of a horseshoe kidney. Arch Chir Neerl 1975: 27:2716.

37. McGregor WR. Bernhard VM. Concomitant aortic aneurysm and horseshoe kidney. Rocky Mt Med J 1975:72:205-9.

38. Barrie WW. Pollock JG. Reid W. Abdominal aortic surgery and horseshoe kidney. J R Coll Surg Edinb 1975: $20: 1247$.

39. Soriano J. Alpert J. Parsonnet V. Brief DK, Brener BJ. Abdominal aortic aneurysm and the horseshoe kidney. J Med Soc N J 1976: 73: 5848 .

40. Ezzet F. Dorazio R. Herzberg R. Horseshoe and pelvic kidneys associated with abdominal aortic aneurysms. Am J Surg 1977; 134: 196-8.

41. Landes RG. Trumbull HR. Nicoloff DM. Abdominal aortic aneurysm with rupture into the inferior vena cava associated with horseshoe kidney. Ann Surg 1978; 187: 329-331.

42. Asperheim BB, Birkeland S. Helgerud P. Horseshoe kidney and ruptured abdominal aortic aneurysm. Scand J Urol Nephrol 1977: 11: 89-92.

43. Brown L, Martinez L. Mannix jr H. Abdominal aortic aneurysm and horseshoe kidney in a 91 -yearold man. Am Surg 1977: 43:531-3.

44. Lobe TE, Martin jr EW. Cooperman M. Vasko J. Evans WE. Abdominal aortic surgery in the presence of a horseshoe kidney. Ann Surg 1978: 188: 71-8.

45. Schwilden ED. Barwegen M. Van Dongen RJAM. Aortenaneurysma und Hufeisenniere: Kasuistik und Literaturuber sicht. Langenbecks Arch Chir 1978; 346: 135-48.

46. Zisis EG. McCann W]. Mahoney WD. Schraft jr WC. Abdominal aortic aneurysm associated with horseshoe kidney. A case report. Vasc Surg 1978: 12: 198-203.

47. McLoughlin MG. Gardner T]. Melville William G. Cake kidney with abdominal aneurysm. Can J Surg 1978: $21: 367$.

48. Brown WO. Dosick SM. Blakemore WS. Abdominal aortic aneurysm and horseshoe kidney. Arch Surg 1979; 114: 860-1.

49. Sidell PM. Pairolero PC. Payne WS, Bernatz PE, Spittell JA. Horseshoe kidney associated with surgery of the abdominal aorta. Mayo Clin Proc 1979: 54: 97-103.

50. Connelly TL. McKinnon W. Smith III RB. Perdue GD. Abdominal aortic surgery and horseshoe kidney. Arch Surg 1980; 115: 145963.

51. Rabitti G. Creazzo V. Gentili C, Bertoletti G. Pogany G. Chidichimo G. Aneurisma dell'aorta addominale associato a rene a ferro di cavallo. G Ital Cardiol 1980: 10: 1408-11.

52. Donati A. Di Bartolomeo R. Turinetto B. Coli G. Galli R. Abdominal aortic aneurysm and horseshoe kidney. J Cardiovasc Surg 1980: 21:632-6.

53. Starr DS. Forster W]. Morris jr GC. Resection of abdominal aortic aneurysm in the presence of horseshoe kidney. Surgery 1981: 89:387-9.

54. Poulias GE. Polemis L. Skoutas B. et al. Successful resection of ruptured abdominal aortic aneurysm into the inferior vena cava, in the presence of a horseshoe kidney. Case report and review of the literature. J Cardiovasc Surg 1982: 23:415-21.

55. Gillet M. Mantion G. Boillot A. Caussin J. Anévrysme de l'aorte abdominale rompu dans la veine cave inférieure et rein en fer à cheval. Chirurgie 1982; 108: 811-5.

56. Du Toit DF. Louwrens H. Klompje J. Groenewald JH. Ruptured abdominal aortic aneurysm and horseshoe kidney. SA Med J 1983: 64: 750-1.

57. Louagie YA. Schoevaerdts JC. D Udekem FD. Ponlot R. Horseshoe kidney and abdominal aortic aneurysm. Acta Chir Belg 1984: 84: 24954 . 58 Gutowicz MA. Smullens SN. Ruptured abdominal aortic aneurysm with horseshoe kidney. J Vasc Surg 1984: 1 :
68991 .

59. Hardin CA. Abdominal aortic surgery and horseshoe kidney. Kans Med 1986; 87: 2745. 
60. Pender DJ. Ruptured abdominal aortic aneurysm with horseshoe kidney. Br J Hosp Med 1986: $35: 414-5$.

61. Martorell A, Callejas JM. Caralps A. Viver E. Aneurisma de aorta abdominal y rinon en herradura. A proposito de un caso. Angiologia 1986; 38: 208-11.

62. Constantino MJ. Montgomery TA. Horseshoe kidney associated with aortic aneurysm. J Med Assoc Ga 1986: 75: 212-4.

63. Van Damme H, Garcez JL, Dereume JP. Anévrysme de l'aorte abdominale et rein en fer à cheval.J Mal Vasc 1987: $12: 241-5$.

64 Moer A. Solheim K. Hesteskonyre og aortaaneurisme. Tidsskr Nor Laegeforen 1987; 107: 540-1.

65. Svensson LG, Persson LA, Cohen PM, Gaylis H. Successful management of ruptured septic aortic aneurysm and horseshoe kidney with multiple renal arteries. A case report. S Afr J Surg 1987; 24: 161-3.

66. Waters DJ. Esper AN, Stanley WE. Abdominal aortic aneurysm repair and the horseshoe kidney. J Am Osteopath Assoc 1987: 87:681-3.

67. Taylor DC, Sladen JG. Maxwell T. Aortic surgery and horseshoe kidney: a challenging surgical problem. Can J Surg 1987: 30: 431-3.

68. Bomalaski MD, Gardner AL, Madison DL. Aortic surgery complicated by horseshoe kidney. Indiana Med 1988; 81: 688-93.

69. Morin JF, Johnston KW. Thoracoabdominal retroperitoneal approach for repair of abdominal aortic aneurysm associated with horseshoe kidney. Ann Vasc Surg 1988: 2: 82-4.

70. Huber D, Griffin A, Niesche J. Frawley J. Gray L. Aortic aneurysm surgery in the presence of a horseshoe kidney. Aust N Z J Surg 1990; 60: $963-6$.

71. Tapper SS, Martin III RS, Edwards WH. Meacham PW. Ruptured abdominal aortic aneurysm and horseshoe kidney. South Med J 1990; 83:2246.

72. Giordanengo F, Vandone P. Pizzocari P. De Monti M. Mattioli A. Aneurisma dell'aorta addominale e rene a ferro di cavallo. Minerva Cardioangiol 1991: 39:97-102.

73. De Brito CJ, Mello Silva LAL., Fonseca Filho VL, Fernandes DCSC. Abdominal aortic aneurysm in association with horseshoe kidney. Int Angiol 1991: 10: 122-5.

74. Yaman M, Wooster D, Bojanowski V, Louch R. Two patients with horseshoe kidney and ruptured abdominal aortic aneurysm. Can J Surg 1991:34: 238-41.

75. Mason RA. Kvilekval KHV, Hartman A. Giron F. The retroperitoneal approach to aortic surgery associated with horseshoe kidney. J Cardiovasc Surg 1991: 32: $763-6$.

76. Giorgetti PL. Bordoni MG. De Monti M. Rignano A. Marenghi MC. Giordanengo F. Rottura di aneurisma dell'aorta addominale in paziente portatore di rene fuso a ferro di cavallo. Minerva Chir 1992; 47: 5963.

77. Bertin F. Christides C. Cornu E, et al. Dissection aigué de l'aorte sous rénale et rein en fer à cheval. J Chir 1992: 129:330-4.

78. O'Hara PJ. Hakaim AG. Hertzer NR. Krajewski LP. Cox GS, Beven EG. Surgical management of aortic aneurysm and coexistent horseshoe kidney: Review of a 31-year experience. J Vasc Surg 1993: 17: 940-7.

79. Julia P. Hanotel MC. Ghalayini B, Fabiani JN. Abdominal aortic aneurysm associated with horseshoe kidney and duplication of the inferior vena cava. Ann Vasc Surg 1993: 7: 587-9.

80. Shortell CK. Welch EL. Ouriel K. Green RM. DeWeese JA. Operative management of coexistent aortic disease and horseshoe kidney. Ann Vasc Surg 1995: 9: 123-8.

81. Moriyasu K. Funami M. Narisawa T, Matsuo Y. Inoue K. Takaba T. The retroperitoneal approach to aortoiliac surgery associated with a horseshoe kidney: Report of a case. Jpn J Surg 1996; 26: 655-7.

82. Artioukh DY, Wake PN. Edwards PR. Moody AP. Problems of abdominal aortic aneurysm associated with horseshoe kidney. Eur J Vasc Endovasc Surg 1997; 14:75-8.

83. Adoumie R. Hamman J. Retroperitoneal repair of an abdominal aortic aneurysm associated with a horseshoe kidney. I Ky Med Assoc 1997; 95: 143-4.

84. Lee F. Quick CRG. Abdominal aortic aneurysm associated with horseshoe kidney and duplication of inferior vena cava: An extraperitoneal approach. Eur J Vasc Endovasc Surg 1997; 14: 406-7

85 Ferko A, Krajina A. Jon B, Lesko M. Woboril Z. Juxtarenal aortic aneurysm associated with a horseshoe kidney. Arch Surg 1997: 132:316-7.

86. Luther B, Sandmann W. Reiher L. Lynen P. Aortenaneurysma bei hufeisenniere: Spezielle diagnostik und therapie. Chirurg 1997; 68: 403-9 
87. Canova G, Masini R, Santoro E. Bartolomeo S, Martini C. Becchi G. Surgical treatment of abdominal aortic aneurysm in association with horseshoe kidney; three case reports and a review of technique. Tex Heart Inst ] 1998; $25: 206-10$.

88. Loftus IK. Thompson MM, Fishwick G, Boyle JR, Bell PRF. Endovascular repair of aortic aneurysms in the presence of a horseshoe kidney.J Endovasc Surg 1998; 5: 278-81.

89. Sonneveld DJA, Van Dop HR. Van Der Tol A. Resection of abdominal aortic aneurysm in a patient with left-sided inferior vena cava and horseshoe kidney. J Cardiovasc Surg 1999; 40:421-4.

90. Kaplan DB, Kwon CC, Marin ML. Hollier LH. Endovascular repair of abdominal aortic aneurysms in patients with congenital renal vascular anomalies. J Vasc Surg 1999; 30: 407-16.

91. De Virgilio C, Gloviczki P, Cherry KJ, et al. Renal artery anomalies in patients with horseshoe or ectopic kidneys: the challenge of aortic reconstruction. Cardiovasc Surg 1995: 3:413-20.

92. Berenger da Carpi. Isagoge breves perlucide ac uberrime in anatomiam humani corporis. Bologne, per Benedictum Hectoris; 1522.

93. Botallus L. De monstroso rene. Bauhinus C. In: Blasius G. ed. Exercitatio anatomica de structura et usu renum. Amsterdam: Frisius A, 1665: 102-8.

94. Darling RC, Messina CR, Brewster DC, Ottinger LW. Autopsy study of unoperated abdominal aortic aneurysms. The case for early resection. Circulation 1977; 56 (3 suppl): II161-4.

95. Grainger R, Lane V. Murphy DM. Horseshoe kidney - a review of the presentation, associated congenital anomalies and complications in 73 patients. Ir Med J 1983; $76: 315-7$.

96 Segura JW. Kelalis PP. Burke EC. Horseshoe kidney in children. J Urol 1972: 108: $333-6$.

97. Zondek LH. Zondek T. Horseshoe kidney and associated congenital malformations. Urol Int 1964: 18:347-56.

98. Thoeni RF. Helical CT of abdominal aortic aneurysm [see comments]. AJR Am J Roentgenol 1996; 166: 457.

99. McCarthy W]. Schneider JR, Shah P, et al. Management of aortic aneurysm and associated urological problems. In: Yao JST, Pearce WH, eds. Aneurysms. New Findings and Treatments. Norwalk, CT. Appleton and Lange. 1995: 275-286.

100. Quick CRG. Chan CLH, Sonoda L. Hart AJ. Midline extraperitoneal approach for elective abdominal aortic aneurysm repair. Eur J Vasc Endovasc Surg 1997; 14: 63-8.

101. Shepard AD, Tollefson DF], Reddy DJ, et al. Left flank retroperitoneal exposure: $A$ technical aid to complex aortic reconstruction. J Vasc Surg 1991; 14: 283-91.

102. May J. White GH. Waugh R, et al. Endovascular treatment of abdominal aortic aneurysms. Cardiovasc Surg 1999: 7: 484-90.

103. Dake MD, Kato N, Mitchell RS, et al. Endovascular stent-graft placement for the treatment of acute aortic dissection. N Eng J Med 1999; 340: 1546-52.

104. Glenn JF. Analysis of 51 patients with horseshoe kidney. New Eng J Med 1959; 14:684-7. 
ChAPTER 10

AORTIC ANEURYSM IN COMBINATION WITH A HORSESHOE KIDNEY: CASE REPORTS 


\section{CASE 1}

A 53-year-old man with a previous history of nicotine abuse, angina pectoris and recurrent urinary tract infections in the presence of a horseshoe kidney presented in our clinic with complaints related to gallbladder stones. Ultrasonography revealed the presence of gallstones in combination with an abdominal aortic aneurysm with a diameter of $37 \mathrm{~mm}$. During follow-up the aneurysm gradually increased in diameter up to $55 \mathrm{~mm}$ and the patient was planned for exclusion of the aneurysm. Aortography confirmed the presence of the horseshoe kidney with a parenchymatous isthmus and showed two renal arteries on the left side and two on the right side. All arteries originated from the aorta above the level of the aneurysm. During operation through a midline incision and transperitoneal approach, the horseshoe kidney and its arteries were identified. The renal isthmus, that crossed the aneurysm anteriorly, was mobilized and retracted cranially. Good exposure of the aneurysm was achieved. Because the two distal renal arteries originated from the aorta, just proximal of the aneurysm, the aorta was clamped between the renal arteries. A tube graft was placed dorsal to the horseshoe kidney and the end-to-end inlay anastomoses were performed in the usual way. Postoperatively the patient did well. The aortic cross-clamping between the renal arteries did not have a negative effect on his renal function. The serum creatinine was $76 \mu \mathrm{mol} / \mathrm{l}$ at day seven postoperatively. The patient was discharged eight days after surgery and is doing well to date, ten years later.

\section{CASE 2}

A 71-year-old man with a history of a myocardial infarction and a transient ischemic attack presented with backaches to the neurology department in a local hospital. A computed tomography (CT) scan was performed of the vertebral column and an abdominal aortic aneurysm was diagnosed. The aneurysm was $65 \mathrm{~mm}$ in diameter. The patient was planned for resection of the aneurysm. After a midline incision and a transperitoneal approach, a horseshoe kidney was discovered, crossing the aneurysm with its parenchymatous isthmus. The local surgeons decided not to exclude the aneurysm and the patient was referred to our hospital for a second opinion. An aortography was performed, showing two renal arteries on the left side and three renal arteries on the right side. The renal arteries did not originate from the aneurysm. At reexploration the aneurysm was approached through the same midline incision and again transperitoneally. The renal isthmus was separated by electrocauter, providing good exposure of the aneurysm. The aorta had to be cross-clamped above the renal arteries, because they originated just proximal to the aneurysm. The aneurysm was opened and a bifurcation graft was put in place. The anastomoses of the graft with the aorta and the iliac arteries were uncomplicated. Postoperatively the patient suffered a pneumonia for which he was treated with antibiotics. Decrease of renal function did not occur, and the patient was discharged from the hospital after 21 days with a serum creatinine of $119 \mu \mathrm{mol} / \mathrm{l}$. Today, seven years later, he is doing well.

\section{CONCLUSION}

These two case reports illustrate that the exclusion of an aortic aneurysm in the presence of a horseshoe kidney can be performed successfully, even though the approach in both cases was not the one that would be advocated according to the study of the previous chapter. In the second case, the horseshoe kidney was not diagnosed during the preoperative work-up, despite the use of CT. When it was discovered during the operation. the local surgeons were wise to ask for a second opinion of a more experienced vascular surgeon. Although the results in this second case are good. division of the renal isthmus should be avoided when possible. 
CHAPTER 11

Summary and conclusions

Samenvatting en conclusies 


\section{SUMMARY AND CONCLUSIONS}

The horseshoe kidney is the most common anatomical renal variation. It represents a fusion anomaly, mainly at the lower poles, occurring between the 4 th and 6 th week of gestation. The renal isthmus connecting both poles usually consists of parenchymal tissue. Horseshoe kidneys display a great variation in origin, number and size of the renal arteries and veins. Besides that there are a number of complications that can accompany the horseshoe kidney, such as hydronephrosis, renal calculi and recurrent urinary tract infections. Due to the organ shortage, horseshoe kidneys are also considered for transplantation. They can be transplanted en bloc into one recipient, or they can be divided and transplanted into two recipients, depending on the number, size and position of the renal arteries and veins and the anatomy of the urinary collecting system. Because of the variation in vascular anatomy, the transplantation of horseshoe kidneys always poses a technical challenge to the transplant surgeon. Due to inexperience and unfamiliarity with the posttransplant results, approximately $30 \%$ of the horseshoe kidneys that are offered for transplantation are discarded, out of fear for technical complications. Another surgical challenge is formed by the combination of a horseshoe kidney and an aortic aneurysm, because of the high number of renal arteries and the overlying renal isthmus. This thesis aims at giving the posttransplant results of horseshoe kidney transplantation and providing a guideline for the transplantation of horseshoe kidneys; furthermore aortic aneurysm repair in the presence of a horseshoe kidney is discussed.

CHAPTER 1 presents a general introduction on the horseshoe kidney and transplantation. The urological consequences of the horseshoe kidney are mentioned, including the operative techniques used to treat some of the complications. The standard surgical technique for renal transplantation is outlined. The need for alternative forms of donation is illustrated by the organ shortage. Some of the alternatives are: living donation, nonheartbeating donation, en bloc transplantation of paediatric kidneys into adult recipients, the Eurotransplant Senior Programme, xenotransplantation, commerce in transplant organs and of course the transplantation of horseshoe kidneys. Finally the technical challenge of an aortic aneurysm in the presence of a horseshoe kidney is mentioned. This combination can surprise a vascular surgeon, especially in the acute situation.

In CHAPTER 2 the normal embryological development of the kidney is described. The anomalies in embryology that result in a horseshoe kidney are outlined, as well as the theories about the reason why this abnormal development occurs. A description of the anatomical characteristics of the horseshoe kidney is made.

The clinical consequences of the horseshoe kidney throughout the medical history are discussed in CHAPTER 3. The history of the horseshoe kidney can be divided into four different eras: the early days of medicine and cadaveric observation when the horseshoe kidney was seen as a rare anatomical curiosity, the second era in which the horseshoe kidney was accidentally discovered at abdominal operations without therapeutical consequences, the third era in which the horseshoe kidney was diagnosed and surgery of the horseshoe kidney was performed: finally the fourth era in which horseshoe kidneys were used for transplantation. In this chapter it is outlined how a congenital malformation that was initially seen as a monstrous anomaly, was finally used to safe life as a renal allograft.

CHAPTER 4 describes a literature review of the transplantation of horseshoe kidneys. A total of 31 case histories, published between 1975 and 1998, were revealed. Of these 21 were transplanted into 38 recipients after division and 10 were implanted en bloc. Nineteen grafts $(41 \%)$ showed immediate function and 21 grafts $(46 \%)$ showed delayed function. Thrombosis and acute rejection. leading to non function was seen in 6 grafts (13\%). The overall success rate was $87 \%$ at a mean follow-up of 22 months. These results of horseshoe kidney transplantation can be considered good. 
The surgical members of the European Society for Organ Transplantation were asked for their opinions regarding the techniques and results of horseshoe kidney transplantation. Their opinions are discussed in CHAPTER 5. Most surgeons advised to explant the horseshoe kidney en bloc. The decision to transplant en bloc or after division of the renal isthmus depended on the morphology of the renal isthmus, the number and position of renal vessels and/or the anatomy of the urinary collecting system. Most surgeons thought that the results of horseshoe kidney transplantation are equal to those of normal kidneys.

In CHAPTER 6 the results of horseshoe kidney transplantation are assessed. For this purpose all data concerning horseshoe kidney transplantations within the Eurotransplant region were collected and were divided into en bloc and split transplantations. From 1983 to 2000,8 horseshoe kidneys were transplanted en bloc and 26 were split and transplanted into 47 recipients. The results of these transplantations were compared to 110 transplantations in a matched control group. No significant differences between the three groups could be found, with respect to the occurrence of primary non function, graft survival, patient survival and posttransplant serum creatinine values.

CHAPTER 7 aims at constructing a decision cascade for the transplantation of horseshoe kidneys. A world-wide survey in search of cases of horseshoe kidney transplantation was performed. Of each case data were collected on the anatomy of the horseshoe kidney and posttransplant results. The correlation between the number of renal arteries and veins and primary non function due to technical failure was studied. In the period from 1975 to 2000,23 horseshoe kidneys were transplanted en bloc and 57 were split and they were transplanted into 97 recipients worldwide. Primary non function was observed in $4.3 \%$ of the en bloc transplanted kidneys and in $13.4 \%$ of the kidneys that were transplanted after division. Postoperative urinary fistula formation after division of the renal isthmus was seen in two patients. There was no rise in the probability of the occurrence of primary non function with an increased number of renal vessels. From this study it can be concluded that the anatomy of a horseshoe kidney should be closely inspected after explantation. The decision to split the horseshoe kidney should be based on the anatomy of the collecting system in the renal isthmus and not only the number, but also the position of the renal vessels.

Three case reports, illustrating the transplantation of horseshoe kidneys are described in ChAPTER 8.

In CHAPTER 9 a guideline for the treatment of patients with an aortic aneurysm in the presence of a horseshoe kidney is given. A literature review combined with local experience provided a total of 176 cases. These were divided into two groups: asymptomatic aneurysms $(n=134)$ and ruptured aneurysms $(n=42)$, both in combination with a horseshoe kidney. Six types of operative approach were described: transperitoneal approach with or without separation of the renal isthmus, retroperitoneal approach, placement of a stent-graft, aneurysmal wrap and exploration without exclusion of the aneurysm. Diagnosis of the horseshoe kidney was made before operation in $81 \%$ of patients in the asymptomatic group, and in $\mathbf{5 5 \%}$ in the ruptured group. Computed tomography proved to be the most reliable diagnostic procedure. Occlusion of renal arteries originating from the aneurysm was reported in $51 \%$ in the asymptomatic group. and in $74 \%$ in the ruptured group. The preferred surgical options for asymptomatic patients with an aortic aneurysm and a horseshoe kidney are the placement of a stent-graft or a retroperitoneal approach; both avoid many of the technical difficulties related to the presence of a horseshoe kidney. The approach of choice for a ruptured aneurysm is transperitoneal. Division of the renal isthmus should be avoided.

To illustrate the dual pathology mentioned in chapter 9, two case reports are described in CHAPTER 10. 
Overall this thesis shows that the horseshoe kidney should not be feared, but treated with respect. The horseshoe kidney can be a complicating factor in transplantation and aortic aneurysm repair. Therefore a careful preoperative preparation should always be performed whenever possible to decide about the preferred approach and to ensure a good result. The posttransplant results of horseshoe kidneys contradict the common thought that classifies them as marginal kidneys. 


\section{SAMENVATTING EN CONCLUSIES}

De hoefijzernier is de meest voorkomende anatomische variatie van de nieren. Het ontstaat tussen de vierde en zesde week van de zwangerschap door fusie van meestal de onderpolen van beide nieren. De isthmus die beide polen verbindt, bestaat meestal uit nierparenchym. Hoefijzernieren vertonen een grote variatie in oorsprong, aantal en omvang van nierarteriën en -venen. Daarnaast kunnen er een aantal complicaties bij hoefijzernieren optreden, zoals hydronefrose, nierstenen en recidiverende urineweginfecties. Vanwege het tekort aan organen, wordt het gebruik van hoefijzernieren voor transplantatie overwogen. Ze kunnen als geheel in één ontvanger ò ze kunnen worden gesplitst en in twee ontvangers worden getransplanteerd. Dit is afhankelijk van het aantal. de omvang en de positie van de nierarteriën en -venen en de anatomie van de calyces. Vanwege de variatie in vasculaire anatomie is de transplantatie van hoefijzernieren altijd een uitdaging voor de transplantatiechirurg. Door onervarenheid en onbekendheid met de posttransplantatie resultaten worden ongeveer $30 \%$ van de hoefijzernieren afgekeurd. nadat ze voor transplantatie waren aangeboden. Dit gebeurt meestal uit angst voor technische complicaties. Een andere chirurgische uitdaging wordt gevormd door de combinatie van een hoefijzernier en een aneurysma van de aorta. Dit wordt veroorzaakt door het grote aantal nierarteriën en de overliggende isthmus van de hoefijzernier. Het doel van dit proefschrift is de posttransplantatie resultaten van de transplantatie van hoefijzernieren te geven. Daarnaast wordt er een richtlijn gegeven voor de transplantatie van hoefijzernieren, alsmede de exclusie van een aneurysma van de aorta in aanwezigheid van een hoefijzernier.

HoOFDSTUK 1 geeft een algemene inleiding over de hoefijzernier en transplantatie. De urologische consequenties van de hoefijzernier worden genoemd, inclusief enkele operatietechnieken om enkele van de complicaties te behandelen. De standaard chirurgische techniek voor de niertransplantatie wordt gegeven. De behoefte aan alternatieve vormen van donatie wordt geillustreerd door het orgaan tekort. Sommige van deze alternatieven zijn: donatie bij leven, non-heartbeating donatie, en-bloc transplantatie van kindernieren in volwassen ontvangers, het "Eurotransplant Senior Programme", xenotransplantatie, handel in organen en natuurlijk de transplantatie van hoefijzernieren. Tenslotte wordt de technische uitdaging van een aneurysma van de aorta in de aanwezigheid van een hoefijzernier genoemd. Deze combinatie kan een vaatchirurg verassen, vooral in de acute situatie.

In HOOFDSTUK 2 wordt de normale embryologische ontwikkeling van de nier beschreven. De afwijkingen in deze ontwikkeling die resulteren in een hoefijzernier worden genoemd. alsmede de theorieën over de oorzaak hiervan. Tenslotte wordt er een beschrijving van de anatomische karakteristieken van de hoefijzernier gemaakt.

De klinische consequenties van de hoefijzernier gedurende de medische geschiedenis worden in HoofDSTUK 3 beschreven. De geschiedenis van de hoefijzernier kan in vier verschillende tijdperken worden ingedeeld. In de begindagen van de geneeskunde werden hoefijzernieren ontdekt tijdens obducties. Ze werden gezien als een vreemde anatomische curiositeit. Gedurende het tweede tijdperk werden de hoefijzernieren ontdekt tijdens abdominale operaties, zonder dat er therapeutische consequenties aan werden verbonden. In het derde tijdperk werden de complicaties, die met een hoefijzernier gepaard kunnen gaan. gediagnosticeerd en werden er operaties op hoefijzernieren uitgevoerd. Tenslotte werden hoefijzernieren, in het vierde tijdperk, gebruikt voor transplantatie. In dit hoofdstuk wordt uiteengezet hoe een congenitale anomalie die aanvankelijk werd gezien als een monsterlijke afwijking, uiteindelijk wordt gebruikt als transplantaat in de behandeling van nierfalen. 
In HoofDSTUK 4 wordt een overzicht gegeven van de in de literatuur gepubliceerde casus van hoefijzernier transplantatie. Een totaal van 31 casus, gepubliceerd tussen 1975 en 1998 werd gevonden. Van deze werden 21 hoefijzernieren gesplitst en in 38 ontvangers getransplanteerd en 10 hoefijzernieren werden en-bloc getransplanteerd. "Immediate function" werd gezien bij 19 (41\%) ontvangers en bij $21(46 \%)$ ontvangers werd een "delayed function" geconstateerd. Thrombose en acute rejectie leidde tot "primary non function" bij $6(13 \%)$ ontvangers. Na een gemiddelde follow-up van 22 maanden was $87 \%$ van de transplantaties succesvol. Deze resultaten van hoefijzerniertransplantatie kunnen als goed worden beschouwd.

De leden van de "European Society for Organ Transplantation" met een chirurgische achtergrond werden om hun mening gevraagd betreffende de techniek en resultaten van de transplantatie van hoefijzernieren. Hun opinie wordt gegeven in HoofDSTUK 5. De meeste chirurgen adviseerden om de hoefijzernier en-bloc uit te nemen. De beslissing om de hoefijzernier en-bloc of na splitsing van de isthmus te transplanteren blijkt af te hangen van de morfologie van de isthmus, het aantal en de positie van de nierarteriën en -venen en/of de anatomie van de calyces. De meeste chirurgen zijn van mening dat de posttransplantatie resultaten van hoefijzernieren gelijk zijn aan die van nieren met een normale anatomie.

HoofDSTUK 6 wordt het onderzoek naar de resultaten van de transplantatie van hoefijzernieren beschreven. Data van alle hoefijzerniertransplantaties binnen het Eurotransplant gebied werden verzameld en verdeeld in en-bloc en split transplantaties. Tussen 1983 en 2000 werden acht hoefijzernieren en-bloc getransplanteerd en 26 hoefijzernieren werden gesplitst en bij 47 ontvangers getransplanteerd. De resultaten van deze transplantaties werden vergeleken met 110 transplantaties in een vergelijkbare controle groep. Met betrekking tot het optreden van "primary non function", transplantaat overleving. patiënt overleving en posttransplantatie serum creatinine waarden konden er geen significante verschillen tussen de drie groepen worden aangetoond.

In Hoofdstuk 7 wordt getracht een beslisboom voor de transplantatie van hoefijzernieren te creëren. Een wereldwijde enquête op zoek naar casus van hoefijzerniertransplantatie werd uitgevoerd. Van elke casus werden data verzameld over de anatomie van de hoefijzernier en de posttransplantatie resultaten. De correlatie tussen het aantal nierarteriën en -venen en het optreden van "primary non function" werd onderzocht. In de periode tussen 1975 en 2000 werden wereldwijd 23 hoefijzernieren en-bloc getransplanteerd en 57 werden er gesplitst en getransplanteerd bij 97 ontvangers. "Primary non function" werd gezien bij $4.3 \%$ van de en-bloc getransplanteerde hoefijzernieren en bij $13.4 \%$ van de hoefijzernieren die na splitsing van de isthmus werden getransplanteerd. Postoperatieve urinewegfistels na splitsing van de isthmus werden gezien bij twee patiënten. Er was geen stijging in de waarschijnlijkheid van het optreden van "primary non function" met het toenemen van het aantal nierarteriën en -venen. Uit dit onderzoek kan worden geconcludeerd dat de anatomie van een hoefijzernier zorgvuldig geinspecteerd moet worden na uitname. De beslissing om een hoefijzernier en-bloc of na splitsing van de isthmus te transplanteren moet worden gebaseerd op de anatomie van de calyces in de isthmus en niet alleen het aantal, maar ook de positie van de nierarteriën en -venen.

Ter illustratie van de transplantatie van hoefijzernieren worden er drie casus beschreven in Hoofdstuk 8. 
In HoOFDSTUK 9 wordt een richtlijn gegeven voor de behandeling van patiênten met een aneurysma van de aorta in aanwezigheid van een hoefijzernier. Een literatuur overzicht, gecombineerd met de locale ervaring leverde 176 casus op. Deze werden verdeeld in twee groepen: asymptomatische aneurysmata $(n=134)$ en geruptureerde aneurysmata $(n=42)$, beide in combinatie met een hoefijzernier. Zes verschillende typen operatieve benadering werden beschreven: transperitoneale benadering met of zonder splitsing van de isthmus van de hoefijzernier, retroperitoneale benadering, het plaatsen van een endovasculaire prothese, omwikkeling van het aneurysma en exploratie zonder exclusie van het aneurysma. De hoefijzernier werd bij $81 \%$ van de patiēnten in de asymptomatische groep en bij $\mathbf{5 5 \%}$ van de patiênten in de geruptureerde groep preoperatief gediagnosticeerd. Computed tomografie bleek de meest betrouwbare diagnostische procedure te zijn. Occlusie van nierarteriển die uit het aneurysma ontspringen, werd bij $51 \%$ van de patiênten in de asymptomatische groep en bij $74 \%$ van de patiënten in de geruptureerde groep gezien. Bij de exclusie van een asymptomatisch aneurysma heeft het plaatsen van een endovasculaire prothese of een retroperitoneale benadering de voorkeur. Beide vermijden vele van de technische problemen gerelateerd aan de aanwezigheid van een hoefijzernier. Bij een geruptureerd aneurysma verdient een transperitoneale benadering de voorkeur. Splitsing van de isthmus van de hoefijzernier moet worden voorkomen.

Om de exclusie van een aneurysma van de aorta in aanwezigheid van een hoefijzernier te illustreren, worden in HoofDSTUK 10 twee casus beschreven.

Over het geheel genomen, laat dit proefschrift zien dat hoefijzernieren niet gevreesd, maar gerespecteerd dienen te worden. De hoefijzernier kan een complicerende factor zijn in transplantatie en de exclusie van aneurysmata van de aorta. Om die reden is een zorgvuldige preoperatieve voorbereiding - indien mogelijk - van belang om te beslissen over de operatieve benadering en om een goed resultaat te waarborgen. De posttransplantatie resultaten van hoefijzernieren spreken de algemene gedachte tegen die ze als marginale nieren classificeert. 
100 
CHAPTER 12

\title{
Acknowledgements
}

\author{
Curriculum Vitae
}




\section{ACKNOWLEDGEMENTS}

After all the work is done, you realise that the writing of a thesis is a team effort and there are many people to thank for their help and inspiration.

First of all I would like to thank the captain of my team, Gauke Kootstra. It was at the pool of the Conrad International Hotel in Singapore in September 1999 when we decided to "give it a go". Your infectious and unlimited enthusiasm and devotion kept me going since then and led to the successful conclusion of this thesis. I immensely enjoyed working with you.

Special thanks also goes to Geert Willem Schurink for patiently correcting all the initial rudimentary thoughts and writing I enthusiastically produced. Your ability to see things in perspective provided the perfect equilibrium to work in. I hope you enjoyed it as much as I did?!

I also want to thank Prof. Dr. Ph.E.V.A. van Kerrebroeck, Prof. Dr. J.H. van Bockel, Prof. Dr. J.P. van Hooff, Dr. H. van Mameren and Prof. Dr. P.H. Petritsch for critically reviewing the manuscript.

The collection of data was one of the more difficult parts of these studies. This thesis would not have existed without the help of all those people in many countries across the world who faithfully send me their data and encouraged me to continue my research. Special thanks goes to Prof. Dr. G. Opelz, who invited me to Heidelberg to use the Collaborative Transplant Study (CTS) database.

I would also like to thank all the employees of the Eurotransplant International Foundation and the Dutch Transplant Foundation, especially Jacqueline Smits, Guido Persijn, Jan de Boer, Bernard Cohen and Bernadette Haase for their enthusiasm and help. Jacqueline, your ability to make statistical logic from the data salads I offered you, was impressive.

Dr. van de Wiel gave me insight in the history of medicine. I enjoyed our morning conversations at your home very much. They were a grateful relieve from the day to day research.

Wim Buurman and Ernst van Heurn gave me the opportunity to combine my work with my research. Although you did not always have the overview you wanted, you trusted my dedication to get both jobs done. Thanks for that.

I would also like to thank my colleagues, Maurice Benders. John Jongen, Wim de Jong. Inge Sijstermans and Tineke Wind for their enthusiasm and willingness to "cover me" from time to time when research and regular work threatened to collide. I must not forget to thank the kidney racers for their unconditional willingness to get me coffee.

Annelies Hoek designed the beautiful cover of this thesis. Throughout my life you have always been interested in the things that occupied me and it is an honour that your work of art graces my thesis.

I am also grateful to Ruud Kool, my friend and first boss in the Winery Duc Jean in Amsterdam. Your good advice and sence of humour enabled me to relativize a lot of "obstacles" on my way. 
Jan Molkenboer and Boaz Meijer, our friendship (and an alleged promise of a trip to the Caribbean?) made it obvious for you both to help me with a lot of practical things. Your enthusiastic support and interest in my work is much appreciated. Thanks for being my "paranimf"!

Finally I want to thank my biggest fans, my parents, for believing in me. Throughout my life you have always motivated me to increase my capabilities and to get the best out of myself. You have done a perfect job for which I am very grateful. 


\section{Curriculum Vitae}

Otto Bernardus Stroosma was born on October 8,1971 in Amsterdam, the Netherlands. He graduated from the Amsterdams Lyceum, in Amsterdam in 1990, after which he started his medical education at the University of Amsterdam. Otto finished Medical School in March 1998 and started his professional career as a senior house officer in the department of Surgery of the St. Lucas Andreas Hospital in Amsterdam. In February 1999 he came to Maastricht to take up a position as a transplant co-ordinator in the department of Surgery of the University Hospital Maastricht. The work undertaken for this thesis was performed there in the years from 1999 to 2001. At present he is still working as a transplant co-ordinator and has been selected for a Urological residency. 

